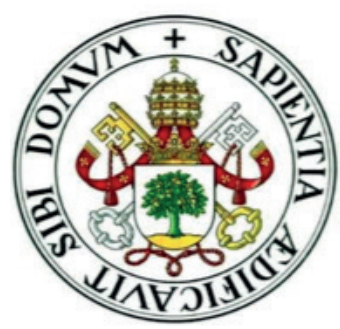

Universidad de Valladolid FACULTAD DE MEDICINA

DEPARTAMENTO DE CIRUGÍA, OFTALMOLOGÍA, OTORRINOLARINGOLOGÍA Y FISIOTERAPIA

TESIS DOCTORAL:

\title{
NIVELES PERIOPERATORIOS DE QUINURENINA: EFECTOS DE LA ANESTESIA GENERAL VS REGIONAL
}

Presentada por D. Rodrigo Sanllorente Sebastián para optar al grado de Doctor por la Universidad de Valladolid

DIRIGIDA POR:

DR. D. EDUARDO TAMAYO GÓMEZ

DRA. DÑA. PILAR ISASI NEBREDA

Valladolid, 2015 
A mifamilia 
"Todo parece imposible hasta que se hace"

Nelson Mandela 


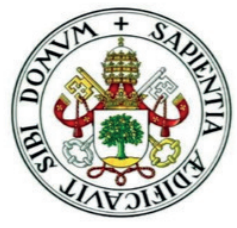

Universidad de Valladolid

\section{Impreso 2T}

\section{AUTORIZACIÓN DEL DIRECTOR DE TESIS}

(Art. 2.1. c de la Normativa para la presentación y defensa de la Tesis Doctoral en la UVa)

Dr. Eduardo Tamayo Gómez con D.N.I. n 13087744-L, profesor del Departamento de Cirugía, Oftalmología, Otorrinolaringología y Fisioterapia de la Facultad de Medicina de la Universidad de Valladolid, y Dra. Pilar Isasi Nebreda con D.N.I. n' 13076171-G, como Directores de la Tesis Doctoral titulada: "NIVELES PERIOPERATORIOS DE QUINURENINA: EFECTOS DE LA ANESTESIA GENERAL VS REGIONAL", presentada por Rodrigo Sanllorente Sebastián con D.N.I. n' 71268124-W, alumno del programa de Doctorado en "Investigación y Cirugía" impartido por el Departamento de Cirugía, Oftalmología, Otorrinolaringología y Fisioterapia, autorizan la presentación de la misma, considerando que reúne todos los requisitos para la presentación, lectura y defensa de la misma.

Valladolid, 20 de Octubre de 2015

Los Directores de la Tesis,

Fdo.: Dr. Eduardo Tamayo Gómez

Dr. Pilar Isasi Nebreda 


\section{AGRADECIMIENTOS}

A todas aquellas pacientes que participaron en la investigación.

Al Doctor Eduardo Tamayo Gómez y la Doctora Pilar Isasi Nebreda por la supervisión y dirección de este trabajo.

A los personales médico, de enfermería y auxiliar que contribuyeron a la finalización de este proyecto.

A los Servicios de Anestesiología y Reanimación y de Investigación del Hospital Universitario de Burgos, por su apoyo y contribución a la realización del presente estudio.

A Lorena y Manuel por robarles un tiempo que no volverá.

A mis familiares, en especial a $\mathbf{M}^{\mathrm{a}}$ Esther por su apoyo constante. 


\section{ABREVIATURAS}

ACTH: Hormona adrenocorticotropa;

ADH: Hormona antidiurética;

ADN: Ácido desoxirribonucleico;

ADP: Adenosin difosfato;

AINE: Antiinflamatorio no esteroideo;

ARN: Ácido Ribonucleico;

ASA: Asociación Americana de Anestesiólogos;

BIS: Índice biespectral;

BPVT: Bloqueo paravertebral torácico;

BT-20: cáncer de mama;

Caco-2: Células;

CAM: Concentración alveolar mínima;

CD4: Linfocitos CD4;

CD8: Linfocitos CD8;

CIN-3: Neoplasia intraepitelial cervical;

COX-2: Ciclooxigenasa 2;

EGF: Factor de crecimiento epitelial;

EL4: Células de linfoma de células T;

ER: Receptor estrogénico;

GABA-A: Ácido gamma amino butírico tipo A;

GH: Hormona del crecimiento; 
HeLa: Línea celular de carcinoma epitelial humano;

Hep-2: Línea celular

HIF: Factor Inducible por Hipoxia;

HL-60: Línea celular HL-60;

HOS: Células HOS de osteosarcoma humano;

HT1080: Células HT1080 de fibrosarcoma;

ICAM-1: Molécula de adhesión intercelular tipo 1;

IDO: Indoleamin-2,3-dioxigenasa;

IL-1ß: Interleuquina 1 beta;

IL-2: Interleuquina-2;

IL-4: Interleuquina-4;

IL-5: Interleuquina-5;

IL-6: Interleuquina-6;

IL-8: Interleuquina-8;

IL-10: Interleuquina-10;

IL-12: Interleuquina-12;

iNOS: Sintasa de óxido nítrico;

IFN-y: Interferón gamma;

KDa: Kilodaltons;

LMR: Ratio linfocitos/monocitos;

mA: Miliamperios;

MADB106: Células MADB106 de cáncer mamario;

MCF-7: Células; 
MDA-MB-231: Línea celular MDA-MB-231 de cáncer mamario;

MDA-MB-468: Células MDA-MB-468 de cáncer mamario;

MMP: Metaloproteinasas de matriz;

MMP-2: Metaloproteinasas de matriz tipo 2;

MMP-3: Metaloproteinasas de matriz tipo 3;

MMP-9: Metaloproteinasas de matriz tipo 9;

MOR: Receptor opioide mu;

NAD: Nicotinamida-Adenin-Dinucleótido;

NF-kB: Factor nuclear kappa B;

NK: Células Natural Killer;

NK-like: Células Natural Killer like;

NK-1: Neurokinina-1;

NLR: Ratio neutrófilos/linfocitos;

OMS: Organización Mundial de la Salud;

PCR: Reacción en cadena de la polimerasa;

PGE-2: Prostaglandina E2;

PLR: Ratio plaquetas/linfocitos;

RPMI-7951: Células RPMI-7951 de melanoma;

SH-SY5Y: Células;

SNC: Sistema nervioso central;

SNP: Sistema nervioso periférico;

STAT-3: Transductor de señal y activador de la transcripción 3 (STAT-3);

TDO: Triptófano-2,3-dioxigenasa; 
TGF- $\beta$ : Factor de crecimiento transformante beta;

TIVA: Anestesia Total Intravenosa;

Th1: Linfocitos helper 1;

Th2: Linfocitos helper 2;

TNF-a: Factor de necrosis tumoral alfa;

VEGF: Factor de crecimiento endotelial vascular;

YAC-1: Línea celular YAC-1 de linfoma de células T;

3LL: Línea celular de carcinoma de pulmón de Lewis; 


\section{DIFUSIÓN DE RESULTADOS}

\section{Comunicaciones nacionales}

Sanllorente R, Stroe M. Datos preliminares de estudio de tolerancia tumoral por I.D.O.: morfina versus paravertebral en cirugía de cáncer de mama. XXX Congreso Nacional y XIV Hispano-Luso de la Sociedad Española de Anestesiología, Reanimación y Terapéutica del Dolor. Madrid. 5 a 7 de Mayo de 2011. 


\section{NIVELES PERIOPERATORIOS DE QUINURENINA: EFECTOS DE LA ANESTESIA GENERAL VS REGIONAL}


NIVELES PERIOPERATORIOS DE QUINURENINA: EFECTOS DE LA ANESTESIA GENERAL VS REGIONAL 
NIVELES PERIOPERATORIOS DE QUINURENINA: EFECTOS DE LA ANESTESIA GENERAL VS REGIONAL

ÍNDICE 
NIVELES PERIOPERATORIOS DE QUINURENINA: EFECTOS DE LA ANESTESIA GENERAL VS REGIONAL 
1.1 HISTORIA DEL CÁNCER Y DE LA ANESTESIA LOCAL Y

REGIONAL

1.2 CÁNCER

1.2.1 Cáncer de mama

1.3 PERÍODO PERIOPERATORIO Y CÁNCER

1.3.1 Cirugía y cáncer ............................................................ 29

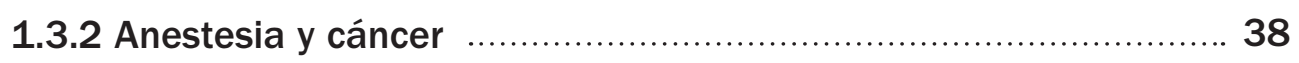

1.3.2.1 Hipnóticos y cáncer ................................................. 38

1.3.2.2 Opioides y cáncer ....................................................... 45

1.3.2.3 Analgesia regional y cáncer ....................................... 49

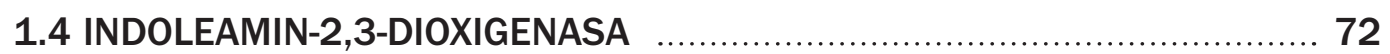

1.4.1 Descripción y función ….................................................. 72

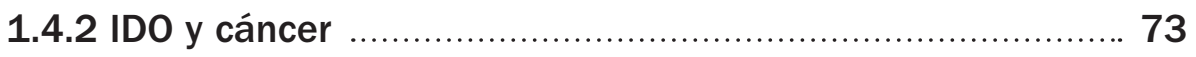

1.4.3 IDO y células inmunes ................................................... 75

1.4.4 IDO y pronóstico oncológico ............................................ 76

1.4 .5 Inhibidores de IDO ........................................................ 77

1.4.6 IDO y cáncer de mama ................................................ 78

1.5 RATIO NEUTRÓFILOS/LINFOCITOS Y CÁNCER _................................... 79

1.5.1 Descripción y función ....................................................... 79

1.5.2 Ratio Neutrófilos/Linfocitos y cáncer ................................ 80

1.5.3 Ratio Neutrófilos/Linfocitos y cáncer de mama ................ 82

2. JUSTIFICACIÓN

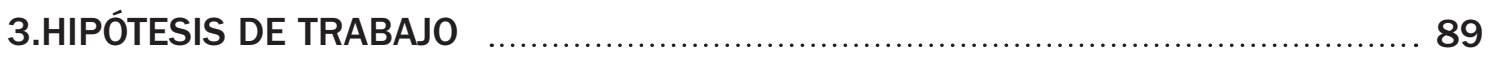

4. OBJETIVOS

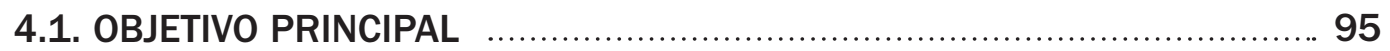

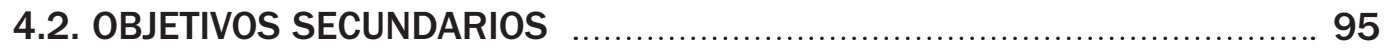


NIVELES PERIOPERATORIOS DE QUINURENINA: EFECTOS DE LA ANESTESIA GENERAL VS REGIONAL

5. MATERIAL Y MÉTODOS

5.1 SERVICIO HOSPITALARIO Y PACIENTES 99

5.2 DISEÑO DEL ESTUDIO 100

5.3 TÉCNICAS Y TRATAMIENTOS RECIBIDOS 102

5.4 DEFINICIONES 105

5.5 VARIABLES DEL ESTUDIO 105

6. RESULTADOS 107

6.1 CARACTERÍSTICAS CLÍNICAS Y DEMOGRÁFICAS DE LAS PACIENTES .... 109

6.2 ACTIVIDAD ENZIMÁTICA IDO 113

6.3 RATIO NEUTRÓFILOS / LINFOCITOS (NLR) 115

7. DISCUSIÓN 119

7.1 MODIFICACIÓN PERIOPERATORIA DE NIVELES DE IDO 121

7.2 IMPACTO DE LA TÉCNICA ANALGÉSICA SOBRE

LA ACTIVIDAD IDO 122

7.3 LIMITACIONES DEL ESTUDIO 126

7.4 APLICACIÓN DE NUESTROS RESULTADOS A LA PRÁCTICA CLÍNICA 127

7.5 FUTUROS ESTUDIOS 128

8. CONCLUSIONES 130

9. BIBLIOGRAFÍA 134 
NIVELES PERIOPERATORIOS DE QUINURENINA: EFECTOS DE LA ANESTESIA GENERAL VS REGIONAL 
NIVELES PERIOPERATORIOS DE QUINURENINA: EFECTOS DE LA ANESTESIA GENERAL VS REGIONAL 


\subsection{HISTORIA DEL CÁNCER Y DE LA ANESTESIA LOCAL Y REGIONAL}

El cáncer como enfermedad no es un descubrimiento de la actualidad, sino que ya existen registros desde el inicio de la Historia de la Humanidad. Se ha informado de la existencia de un tumor óseo en una mandíbula encontrada en África Oriental que data de la era Pleistocénica (1.600.000 a 100.000 años a.C.).

De igual manera se han descrito restos óseos afectos por sarcoma osteogénico en el Antiguo Egipto, así como tumores de mama y de vejiga, siendo este último tan frecuente como hoy día. Por su localización más externa, los tumores de mama fueron los primeros descritos en la Antigua Grecia. El término cáncer se introduciría más adelante.

Atosa, esposa de Darío I, rey de Persia, ocultó un tumor de mama hasta que por su importante crecimiento lo consideró peligroso, mostrándoselo a su médico Democedes. Estos hechos fueron recogidos por Herodoto, conformado la mención antigua más específica sobre el cáncer de mama. Asimismo, las literaturas hindú y persa presentan documentos descriptivos semejantes de este tipo tumoral.

Es a partir de Hipócrates (460-370 a.C.) cuando comienzan a emplearse los términos carcinos y carcinoma para referirse a los cánceres progresivos. Expuso además la teoría de los cuatro humores (sangre, moco, bilis amarilla y bilis negra) cuyo desequilibrio engendraba enfermedades. Sus ideas persistirían durante siglos.

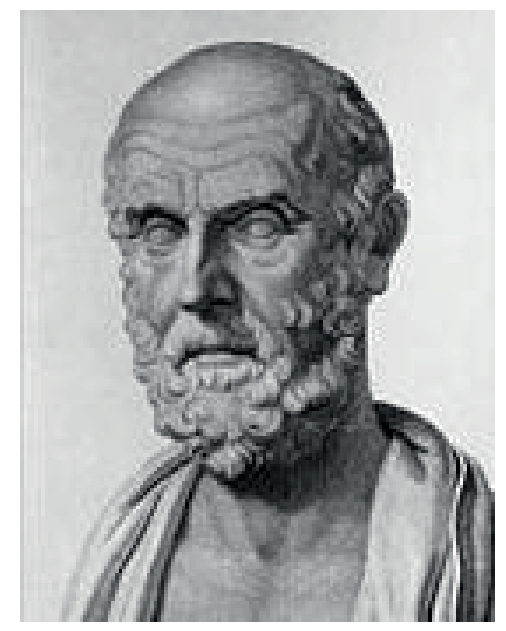

Figura 1. Hipócrates 
Chirurgia Magna, obra del cirujano Guy de Chauliac de la Escuela de Salerno, recogía una amplia descripción de los tumores y sus tratamientos. Posteriormente, Galeno observó cánceres externos o las consecuencias de los internos cuando drenaban hacia el exterior como líquidos negruzcos y restos de pus y tejidos necróticos. Mantuvo un sistema conceptual basado en la teoría humoral, por el que un desequilibrio a favor de la bilis negra, que no podía ser drenada, era la causa del cáncer. El tumor primitivo constituía el fin, por el que la bilis negra luchaba por salir al exterior y no el comienzo del proceso, de manera que la extirpación no podía ser efectiva en la curación. Las limitaciones técnicas quirúrgicas, la más importante, la ausencia de anestesia, añadidas al concepto anterior, explica el porqué los pacientes con cáncer, durante siglos, salvo excepciones, no fueran tratados.

No obstante, el origen de los primeros intentos de alguna forma de analgesia o anestesia local es tan antiguo como el cáncer. Los antiguos egipcios ya usaban una variedad de analgésicos incluyendo hiosciamina, escopolamina, amapola del opio, cerveza, enebro, y levadura para tratar una diversa variedad de dolencias.

La cultura india antigua empleaba medicina herbal y yoga para superar el dolor y crear un balance interno, y en la antigua china se emplea acupuntura para canalizar adecuadamente las energías negativas y drenar el dolor del cuerpo, desde hace más de 2.000 años.

Grandes filósofos y médicos griegos estaban preocupados con la caracterización y entendimiento del dolor. Consideraron el dolor, por primera vez, como una función sensorial que podría derivar de la estimulación periférica. Las primeras enseñanzas de Aristóteles (384-322 a.C.) describieron el dolor como una emoción originada y procesada en el corazón y no fue hasta Galeno de Pergamón cuando la gente reconoció que el cerebro era el órgano responsable de la sensación dolorosa, hecho previamente considerado por Platón.

En la época romana, con la mejora del conocimiento anatómico, se afianzó la idea del cerebro como centro de procesamiento doloroso, mejorándose además terapias como el empleo de fármacos, frío, calor o masajes para el tratamiento del dolor, lo que establecería las bases de la cirugía como tratamiento de enfermedades.

El debate del origen y centro de procesamiento del dolor se mantuvo a lo largo de la Edad Media, realizándose las cirugías invasivas sin ningún tipo de anestesia. Avicena (980-1037) describió cómo la sensación dolorosa podía ser alterada en varias enfermedades. Aunque durante el periodo dominado por la medicina árabe, el 
concepto de cáncer no tuvo cambios significativos, Avicena efectuó una muy detallada descripción del cáncer de estómago.

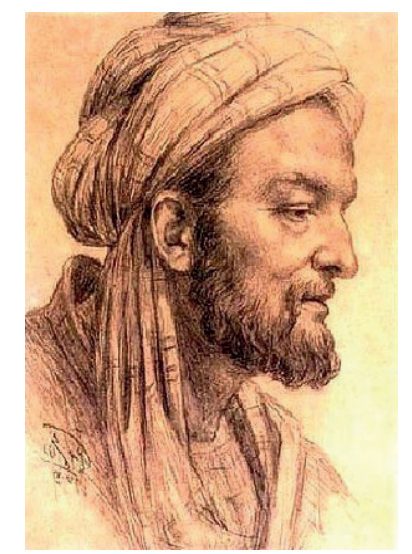

Figura 2. Avicena

Durante la Edad Media, especialmente siglos XI a XIV, la Medicina comienza una decadencia con una vuelta hacia las corrientes interpretativas más primitivas. Sin embargo, Lanfranco de Milán (1250-1306) pone las bases de la cirugía científica, adoptando, en el caso de la oncología, las intervenciones precoces y radicales del cáncer mamario como estrategia, hecho que posteriormente se objetivaría como trascendental.

La medicina hipocrática y galénica no fue puesta en cuestión hasta el Renacimiento. J. Fabricio (1537-1619) defendió la extirpación completa de los tumores frente al riesgo de hacerlo de forma incompleta. El descubrimiento del microscopio en 1529 permitió descartar las teorías galénicas al no encontrarse, entre otros hechos, la bilis negra.

La medicina experimental se inicia en el siglo XVII. Es en este siglo cuando se sustituye el concepto de cáncer como enfermedad constitucional por el de enfermedad local o regional. Deja de ser una enfermedad oculta, siendo incluso objeto de grandes pintores como Rubens en su obra titulada Las tres gracias.

Dos grandes avances facilitarán el progreso de la cirugía: la anestesia y la antisepsia. Morton facilitó la extirpación de un tumor en el cuello de un paciente anestesiado mediante éter. La compresión directa de los nervios y la aplicación directa de hielo en zonas periféricas antes de la intervención quirúrgica se remonta muchos años antes, pero fueron regularmente empleados desde la segunda mitad del siglo XVIII. 
Newton (1642-1727) y Hartley (1705-1757) describieron el papel potencial de los nervios en la transmisión del estímulo doloroso desde la periferia hasta el cerebro. Los intentos iniciales de control médico del dolor se originaron típicamente de las plantas e incluyeron el opio (Papaver somniferum), alcohol, Mandrake (Atropa mandragora), belladonna (Atropa belladona), y marihuana (Cannabis). Freidich Wilhelm Sertüner (1783-1841) aisló morfina de la planta del opio en 1803.

El desarrollo occidental de la ciencia y la tecnología creció progresivamente durante la mitad del siglo XIX. La aspirina (ácido acetil salicílico) fue lanzada al mercado en 1899 por la compañía Bayer y rápidamente se convirtió en el principal agente terapéutico contra el dolor suave a moderado.

Decenios antes de que llegara a ser una posibilidad práctica, se llevó a cabo la primera valoración detallada de los beneficios de la anestesia local por parte de James Young Simpson. El documento, publicado en 1848, además de hacer referencia a métodos antiguos, describía sus experimentos fallidos de aplicación tópica de distintos líquidos y vapores con el fin de producir anestesia local. La aplicación de fármacos a los nervios transmisores en un primer intento de modificar el dolor neurálgico fue realizada y publicada por Francis Rynd (1801-1861). Schiff en 1858, fue el primero en formular, tras experimentación animal, la teoría de que el dolor, como otras modalidades sensoriales, era transmitido a lo largo de una vía de conducción independiente.

En tiempos precolombinos, los nativos de Sudamérica empleaban hojas de coca (erythroxylon coca) con fines místicos, religiosos, sociales, nutricionales y médicos. Los nativos encontraron que masticar las hojas de coca les aliviaba el hambre y la fatiga, y la hoja poseía efectos tanto analgésicos como propiedades alucinatorias. Durante los rudimentarios procedimientos quirúrgicos, obtenían anestesia local al masticar las hojas de la planta permitiendo a la saliva resultante introducirse en las incisiones practicadas. Masticar las hojas también calmaba el hambre, daba vigor a los deprimidos y cansados.

Bernabé Cobo documentó el primer uso analgésico de la cocaína en 1653 al describir la práctica inca de usar las hojas de coca para curar el dolor dental. Scherzer, durante un viaje a Sudamérica, observó que las hojas al ser mascadas adormecían la lengua, y quiso convertirse en la primera persona en documentar en la literatura sus cualidades anestésicas.

Tras amplia experimentación, Gaedicke en 1855 aisló, por primera vez, el alcaloide activo presente en las hojas de coca, y lo llamó eritroxilina. Posteriomente, 
Friedrich Gaedcke (1834-1861) lo aisló en forma cristalina, Ilamándolo cocaína, documentando su efecto anestésico sobre la lengua al saborearlo.

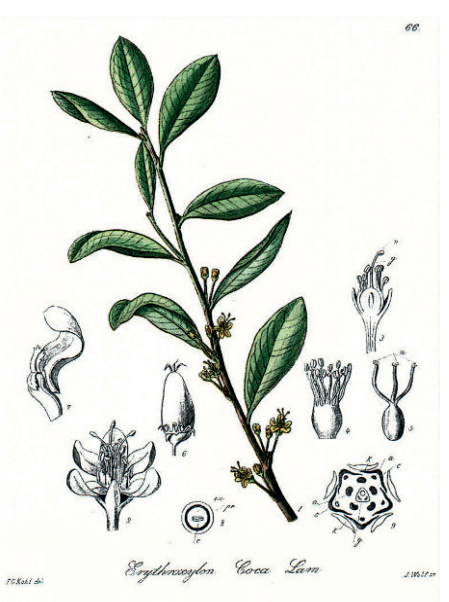

Figura 3. Hoja de coca

El desarrollo de agujas hipodérmicas y jeringas constituyó un prerrequisito importante para poder llevar a cabo un bloqueo anestésico regional. En 1845, Francis Rynd describió los potenciales beneficios de la inyección perineural de opioides sobre el dolor neurálgico, pero introdujo la solución mediante gravedad a través de una cánula, tras retirar el trócar. Alexander Wood, en 1853, inventó la aguja hueca y Charle Gabriel Pravaz fabricó una jeringa a la que acopló la mencionada aguja.

Sigmund Freud, interesado en la cocaína con objeto de curar la adicción de un amigo cercano a la morfina, consiguió obtenerla a través de empresa fabricante Merck, la investigó y escribió destacando sus propiedades. Carl Koller era un cirujano residente del Hospital General de Viena, donde conoció a Freud. Koller debía hacer un importante trabajo de investigación para ser nombrado asistente, puesto con el que soñaba. El desarrollo de la cocaína como anestésico local es atribuido a Carl Koller. Previamente a la uso de la cocaína, la cirugía oftalmológica era casi imposible de realizar, ya que los anestésicos generales inducían tos y vómitos, que debían evitarse durante la citada cirugía oftalmológica. Carl Koller experimentó con una solución diluida de cocaína sobre la córnea de su propio ojo, tras probar a instilarla en el saco conjuntival de una rana y que ésta permitiera la manipulación corneal sin defensa refleja. Se emocionó con su efecto anestésico y unos días más tarde del mismo año (1884) demostró la efectividad de la cocaína en la membrana mucosa en una conferencia en el congreso de oftalmología en Heidelberg, aunque no personalmente, sino a través del doctor Brettauer. Así, Koller proclamó el empleo de la cocaína como un agente anestésico. Freud terminó refiriéndose a su colega como "Coca Koller". 


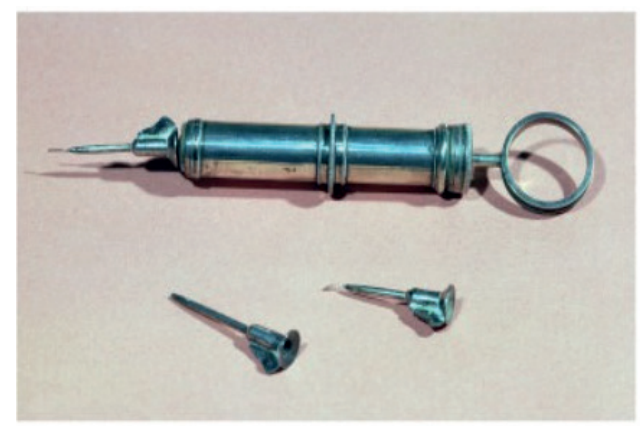

Figura 4. Jeringa y aguja de Wood

Von Anrep (1854-1925), tras desarrollar una solución diluida de cocaína, observó que cuando era inyectada causaba adormecimiento en la piel durante unos 35 minutos y las pupilas se dilataban con el goteo sobre el ojo. La principal ventaja de la anestesia local con cocaína residía en que se anestesiaba únicamente la zona del cuerpo en que se realizaba la intervención quirúrgica.

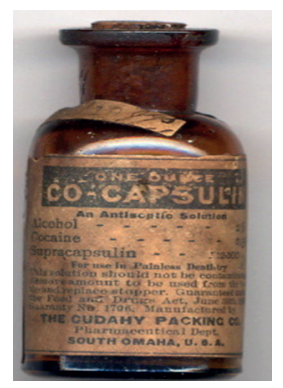

Figura 5. Presentación farmacéutica de cocaína

Finalmente, fue William Halsted (1852-1992) quien en 1885 realizó el primer bloqueo de nervios periféricos accesibles, en concreto del nervio alveolar inferior empleando cocaína en solución al $4 \%$. De esta manera, se obtuvo anestesia de conducción en zonas periféricas. Halsted y Hall también llevaron a cabo un variedad de bloqueos nerviosos periféricos sobre estudiantes de medicina además de sobre ellos mismos. Corning, habitual asistente del Hospital de Roosevelt de Nueva York, lugar donde desarrollaron sus investigaciones Halsted y Hall, introdujo la idea de que producir anestesia por abolición de la conducción de los nervios sensitivos mediante técnicas apropiadas, debe ocupar un lugar destacado en la mente de cualquier médico progresista. Entre otras hazañas, descubrió que la acción anestésica de la cocaína podía prolongarse con la compresión y oclusión venosa de la extremidad proximal al punto de inyección, y además fue el primero en realizar una anestesia espinal con cocaína en perros. Tras demostrar que la toxicidad de la cocaína era proporcional a su tasa de 
absorción, Braun (1862-1934) recomendó el empleo de adrenalina tanto para reducir dicha absorción, como para prolongar la duración de la acción de la cocaína por un efecto similar al de compresión mecánica de los vasos sanguíneos, efecto observado durante el empleo de la misma en cirugía oftalmológica y otorrinolaringológica. Aunque los beneficios de la cocaína se hicieron populares, la toxicidad y capacidad de adicción salieron a la luz, incluso entre los propios investigadores. Numerosas fatalidades fueron comunicadas pocos años después de su introducción. A pesar de estas desventajas, la cocaína fue ampliamente empleada durante casi 10 años.

François-Frank demostró que el fármaco limitaba no sólo la conducción de fibras sensitivas sino también de las motoras, y en 1891 acuñó el término bloqueo a la infiltración perineural de cualquier región corporal. Braun fue el primero en aplicar el término anestesia de conducción.

Los esfuerzos para reducir la toxicidad de la cocaína manteniendo unos periodos de actuación adecuados, no obtuvieron los éxitos esperados hasta la síntesis en 1904 de la procaína (novocaína) por parte de Einhorn. La síntesis de la lidocaína, en 1948 por Löfgren permitió la estabilidad química y la ausencia de sensibilización.

Willstatter y asociados explicaron en 1895 su estructura química, el metil éster ácido benzoico, iniciando investigaciones en ésteres ácido benzoicos. Aunque numerosos se introdujeron otros compuestos sintéticos con propiedades anestésicas, fueron incapaces de sustituir a la cocaína. Mientras tanto, Einhorn tras numerosos años de experimentación con varios compuestos sintetizó con éxito la procaína en 1904. Este anestésico local era menos tóxico y, lo que era más importante, no causaba adicción. La procaína se convirtió en el anestésico local de elección durante los siguientes $\mathbf{4 0}$ años, aunque su uso estaba limitado por su corta duración de acción y por la posibilidad de provocar reacciones alérgicas. La dibucaína (1925) y la tetracaína (1928) presentaban una mayor duración de acción, pero continuaban presentando un riesgo alérgico inaceptable.

Erdman, por 1940 estaba experimentando con el alcaloide Gravina y se sorprendió de encontrar un efecto de adormecimiento de la droga sobre la lengua. Probablemente saborear los agentes químicos era una manera de determinar algunas propiedades de los agentes químicos. Fue Löfgren en 1943 quien continuó el trabajo de desarrollo y sintetizó de forma exitosa la lidocaína, un derivado anilínico. Esto anunciaba una nueva era de un agente anestésico no tóxico. La lidocaína sigue empleándose hoy día encontrando una aceptación general como un agente anestésico local efectivo y seguro. Desde entonces muchos más agentes anestésicos han sido desarrollados, (mepivacaína en 1957, bupivacaína en 1957, prilocaína en 1969, etidocaína en 1972) 
mostrando algunos un menor tiempo de latencia y una mayor duración de acción. Los de más reciente desarrollo son la ropivacaína y levobupivacaína, con una mayor duración de acción, menor bloqueo motor y una menor toxicidad cardiaca. No obstante, se continúa investigando en búsqueda del agente anestésico ideal.

Por otro lado, mientras las técnicas neuraxiales han cambiado mínimamente a lo largo de los años, los bloqueos nerviosos periféricos han evolucionado considerablemente. Inicialmente, la correcta colocación de la aguja a la hora de la realización del bloqueo era realizada bajo los conocimientos anatómicos estimando la localización de los nervios a bloquear. Más adelante, las técnicas requerían la comunicación de parestesia por parte del paciente durante la punción, además de la sensibilidad del anestesiólogo para detectar los distintos pops o clicks al atravesar los distintos planos anatómicos.

Aunque en 1966 aparecieron los primeros dispositivos portátiles estimuladores de nervios dispuestos para la práctica clínica, no fue hasta 1984 cuando presentó un amplio crecimiento e interés tras el diseño de agujas especiales para la estimulación nerviosa, con aislamiento en todo su recorrido excepto la punta. La localización de los nervios a través de sus respuestas motoras condujo a una mayor tasa de bloqueos exitosos incluso con menores volúmenes de anestésico local, además de menor aparición de lesiones nerviosas.

La mejora más reciente en el campo de la anestesia locorregional la conforma el empleo de ecografía para guiar la localización de las estructuras anatómicas y aguja, presentándose incluso como el nuevo gold standard. Mediante ultrasonidos los nervios a bloquear se pueden ver, siendo posible localizarlos de forma efectiva antes de la inyección del anestésico local. La ventaja que presenta es que las variaciones individuales en la anatomía no afectarán a la tasa de éxito en el bloqueo [1-6].

\subsection{CÁNCER}

El cáncer continúa constituyendo el mayor problema de salud pública de Estados Unidos además de otros países [7]. A pesar de la considerable inversión en prevención, su incidencia continúa incrementando. Se trata de la segunda causa de muerte tras las enfermedades cardiovasculares, con 1 fallecimiento de cada 4 . La creciente incidencia de neoplasias lleva a considerarlas un problema de salud pública. El cáncer es una enfermedad de muy diversa localización y cada vez más frecuente. La principal causa de fallecimiento en el paciente oncológico es la recurrencia tumoral y la aparición de metástasis a distancia con el paso del tiempo [8-10]. 
De forma añadida, dados los mejores resultados de los tratamientos oncológicos, más personas viven con cáncer, o son curadas del mismo y, lamentablemente muchas de ellas tendrán enfermedad o dolor crónico relacionado con el tratamiento, precisando analgesia.

\subsubsection{Cáncer de mama}

El cáncer de mama representa entre el 20 y $30 \%$ de los tumores malignos en la mujer occidental, constituyendo, así, el tumor más frecuente y la principal causa de muerte por cáncer. Su incidencia en España varía entre 40 y 75 por cada 100.000 mujeres. Existe un $5 \%$ de probabilidad de que una mujer española desarrolle cáncer de mama antes de los 75 años. Presenta una supervivencia del $77 \%$ a los 5 años, siendo un pronóstico relativamente bueno, aunque influido por múltiples factores [10].

La máxima incidencia se presenta por encima de los 50 años, y un 6\% aproximadamente se diagnostica en mujeres menores de 35 años. Más del $99 \%$ de los casos aparecen en mujeres. Los tipos más frecuentes de tumores de mama son el carcinoma ductal (80\%) y el carcinoma lobulillar. Del total de tumores de mama, únicamente el $5-10 \%$ son de carácter hereditario.

Una fracción importante de estas pacientes desarrollará metástasis a distancia tras el diagnóstico. La aparición de estas metástasis supone un pronóstico desfavorable con un menor tiempo de supervivencia y una mayor refractariedad a las distintas terapias. Se estima que del $\mathbf{3 0}$ al $\mathbf{4 0} \%$ de las pacientes fallecerá a causa de la enfermedad metastásica, a pesar de la extirpación tumoral quirúrgica.

Con respecto a su etiología, aún no totalmente aclarada, se han identificado ciertos factores de riesgo como edad, raza blanca, consumo de alcohol, aparición temprana de la primera regla, menopausia tardía, historia familiar, antecedentes personales, enfermedades previas de la mama, primer embarazo tardío, nuliparidad y terapia hormonal sustitutiva prolongada.

La quimioterapia y radioterapia forman parte importante del tratamiento multidisciplinar oncológico, pero es la escisión quirúrgica la que ofrece la mejor proyección hacia el pronóstico favorable.

El tratamiento y el pronóstico del cáncer de mama dependen ampliamente del estadio en que se encuentra el tumor. El sistema TNM permite estadificar la enferme- 
dad en función del tamaño tumoral $(\mathrm{T})$, la afectación ganglionar $(\mathrm{N})$ y la presencia de metástasis $(\mathrm{M})$ :

Tabla I. Estadios tumorales en cáncer de mama

\begin{tabular}{|l|l|}
\hline Estadio & \\
\hline O & In situ \\
\hline I & $<2 \mathrm{~cm}$ \\
\hline II & $2+$ gglio axila \\
& $2-5 \mathrm{~cm} \pm$ gglio \\
& $>5 \mathrm{~cm}$ sin gglio \\
\hline III & $<5 \mathrm{~cm}+$ gglio \\
A & $>5 \mathrm{~cm}+$ gglio \\
& Pared o piel \\
B & 10 gglios axilares \\
C & Axilares \\
& Clavícula \\
\hline IV & Diseminación \\
\hline
\end{tabular}

\subsection{PERIODO PERIOPERATORIO Y CÁNCER}

La cirugía se mantiene como el principal tratamiento dirigido hacia la curación de los tumores sólidos. La escisión quirúrgica del tumor primario representa la primera oportunidad de erradicar el cáncer porque se elimina la mayor fuente de células con posibilidad de metastatizar, limitando el potencial para la aparición de nuevas mutaciones, y reduciéndose los niveles sistémicos de sustancias inmunosupresoras de origen tumoral.

Sin embargo, actualmente, el periodo perioperatorio en cirugía oncológica es considerado de interés crucial en cuanto a la vulnerabilidad a la aparición de recurrencia tumoral o de metástasis a medio o largo plazo tras la intervención quirúrgica [11]. Al menos un trabajo ha mostrado la aparición de un pico adicional postquirúrgico de incidencia de mortalidad que no se presenta en aquellos pacientes no tratados quirúrgicamente [12]. 
Así, este corto periodo parece tener un desproporcionado alto impacto en las tasas de recurrencia, representando una ventana de oportunidad importante y apenas sin explorar para mejorar el pronóstico.

\subsubsection{Cirugía y cáncer}

La exposición a ciertas situaciones o condiciones de estrés tanto orgánicas como psicológicas, como una intervención quirúrgica, la muerte de un ser querido, u otros eventos traumáticos, ha sido asociada con tasas más altas de infecciones, crecimiento tumoral y muerte [13]. Está demostrado que el estrés provoca un aumento del crecimiento tumoral en modelos animales. Aún es más, incluso una única exposición al estrés u hormonas de estrés durante un periodo crítico de progresión tumoral puede incrementar la mortalidad del cáncer [14].

De esta forma, se ha sugerido que la cirugía acelera, de alguna manera, el desarrollo de las posibles micrometástasis preexistentes y promueve el establecimiento de nuevos focos metastásicos. Son varios los mecanismos potenciales propuestos directos e indirectos para explicar la acción de la cirugía como promotora de las metástasis:

En primer lugar disponemos, a día de hoy, de varias investigaciones que demuestran que muchos pacientes oncológicos ya albergan micrometástasis, clínicamente indetectables, en el momento de someterse a la intervención quirúrgica de extirpación tumoral [15].

De forma añadida, la manipulación quirúrgica de la masa tumoral promueve la liberación y dispersión de millones de células tumorales que también llegan a alcanzar la circulación sanguínea [16-17]. Es posible detectar dichas células malignas en sangre mediante la técnica de reacción en cadena de la polimerasa (PCR), objetivándose que el número de ellas aumenta tras la intervención quirúrgica [18]. Recientemente, además, ha sido demostrado que el número de estas células tumorales circulantes en sangre medidas en el postoperatorio constituye un factor independiente de predicción del riesgo de recurrencia de ciertos tumores malignos, como por ejemplo el cáncer colorrectal.

Enfermedad Mínima Residual es el término acuñado para describir las células tumorales que permanecen tras la cirugía potencialmente curativa. Puede tratarse de depósitos microscópicos o micrometástasis, incluso en los márgenes quirúrgicos. Así, se sospecha, entre otras cosas, que la respuesta del huésped al estrés quirúrgico puede proveer condiciones óptimas para la persistencia de esta Enfermedad Mínima 
Residual tras la cirugía, que a medio-largo plazo puede desarrollarse para formar metástasis clínicamente detectables [16-19].

Por otro lado, cualquier posibilidad de metastatización de todo tumor depende del equilibrio entre el potencial metastásico del propio tumor y las defensas antimetastásicas del huésped [20], y en el periodo perioperatorio se fomenta cierto grado de inmunosupresión multifactorial que suele ser transitorio pero de tal importancia que puede ser vital $[21,22]$. Se encuentra descrito que es preciso un sistema inmune celular intacto para evitar el desarrollo metastásico. Aunque el grado que alcanza la vigilancia inmune hacia el tumor, especialmente en humanos, no es del todo conocido, está demostrado que la aparición de esta inmunosupresión perioperatoria está asociada a un incremento tumoral y metastásico en modelos animales, por lo que se baraja la posibilidad de que podría también encontrarse detrás de la recurrencia tumoral encontrada en humanos, incluso a pesar de una resección completa del tumor primario.

A la hora de establecer categóricamente una relación entre la supresión del sistema inmune y las elevadas tasas de malignidad en humanos nos encontramos con un obstáculo importante, ya que mientras la infección originada a consecuencia de la inmunosupresión puede diagnosticarse a los días del contacto con el agente estresante o inmunosupresor, es necesario un periodo largo y variable entre la inmunosupresión inducida por estrés quirúrgico y la detección de la recurrencia o metástasis potencialmente relacionada.

El sistema inmune corporal está modulado por una red compleja e integrada de mediadores solubles llamados citoquinas. Éstos son liberados por varios tipos celulares y actúan tanto sinérgica como antagónicamente. Algunos ejemplos son las interleuquinas, interferones, y el factor de necrosis tumoral alfa (TNF-a. Algunas de estas citoquinas presentan efectos antitumorales al promover y estimular la capacidad del sistema inmune antitumoral, mientras otras son protumorales e inhiben una respuesta inmune efectiva permitiendo el crecimiento tumoral. Asimismo, las células tumorales también pueden responder a estas moléculas [23].

Durante las fases iniciales de proliferación y mutación, las células tumorales son débilmente antigénicas, encontrándose ausencia de respuesta inmune. A medida que estas células van mutando muestran mayor antigenicidad, iniciando una respuesta inmunológica, o inmunovigilancia, consistente en la identificación y destrucción específica de las células cancerígenas por parte del sistema inmune [24,25]. Desafortunadamente, este mismo proceso puede encauzar la selección de células tumorales inmunorresistentes que han desarrollado mecanismos de escape para evadir dicho sistema inmune. Las células tumorales metastásicas de ratones inmunocompetentes 
presentan modificaciones genéticas que les permiten protegerse de la inmunidad del huésped, modificaciones, aquéllas, que no se observan cuando los ratones están inmunocomprometidos.

Entre los componentes de la inmunidad celular a quienes se les ha atribuido acción antitumoral y antimetastásica se incluyen los linfocitos T citotóxicos, las células mononucleares, las células dendríticas y especialmente las células Natural Killer (NK) [26].

La interacción del sistema inmune en forma de respuestas linfocitarias in vitro contra el tumor autólogo escindido se ha mostrado como la mejor variable predictora de las tasas de supervivencia siendo incluso superior al estadío tumoral. De forma similar, es posible observar una mayor tasa de tumores y un incremento dramático en la progresión metastásica en pacientes inmunocomprometidos, como los pacientes transplantados [22].

En los últimos años, grandes avances en inmunoterapia antitumoral han permitido incrementar la supervivencia de los pacientes, empleando incluso células $\mathrm{Na}$ tural Killer recombinantes. Los resultados son prometedores, dado el beneficio en supervivencia mostrado cuando los modelos animales reciben inmunoestimulación perioperatoriamente.

Dado el descubrimiento de subpoblaciones linfocitarias con actividad específica antitumoral, se ha sugerido un papel aún mayor que el previamente asumido para la inmunidad celular en el control de las células malignas y de la Enfermedad Mínima Residual. Hay que remarcar que la extirpación del tumor primario habitualmente elimina la inmunosupresión de origen tumoral permitiendo potencialmente a la actividad inmune postoperatoria actuar contra la Enfermedad Mínima Residual.

La producción de citoquinas puede dividirse en 2 categorías dependiendo del perfil funcional secretor de los linfocitos T helper: las células de tipo 1 (Th1) generalmente median la respuesta inmune celular a través de las actividades de los linfocitos citotóxicos, NK y macrófagos e incluye la producción de citoquinas, interferón gamma (IFN-y), TNF-a e interleuquina-2 (IL-2). Poseen efecto antitumoral. Las células de tipo 2 (Th2) potencian las reacciones inmunes mediadas por anticuerpos, e incluyen la producción de interleuquina-4 (IL-4), interleuquina-5 (IL-5), e interleuquina-10 (IL-10). Las células de ambos grupos, Th1 y Th2, se inhiben de forma recíproca; así, las IL-4 e IL-10 liberadas por las células linfocitarias Th2 muestran efectos antiinflamatorios, inhibiendo la actividad de las células Th1 y estimulando las Th2 y las respuestas inmunes humorales [27]. 
Entre los mecanismos responsables del control de los tumores malignos se encuentran las células Natural Killer (NK), una subpoblación de leucocitos encargada de reconocer y matar células tumorales y células infectadas por virus. Investigaciones en animales han mostrado que las células NK juegan un importante papel en el control de la leucemia y los tumores sólidos, especialmente durante la invasión metastásica. Estudios en humanos han encontrado una correlación entre los niveles de actividad de las NK y la susceptibilidad a varios tipos diferentes de cáncer. Por ejemplo, pacientes que presentan valores bajos de actividad de células NK como en el síndrome de Chediak-Higashi, síndrome linfoproliferativo asociado al cromosoma $\mathrm{X}$, presentan mayores incidencias de cáncer. De igual manera, en el contexto perioperatorio, aquellos pacientes con bajos niveles preoperatorios de actividad NK muestran una mayor incidencia de morbilidad y mortalidad durante y tras la cirugía de resección tumoral. Y, de forma similar, se ha observado mejor pronóstico postoperatorio en cáncer de mama cuando los niveles de esta actividad eran altos en el momento de la cirugía en cáncer colorrectal, gástrico, pulmonar y de cabeza y cuello [28].

La respuesta al estrés quirúrgico representa un mecanismo celular universalmente conservado de defensa y curación frente al daño tisular. Sabemos que la incisión quirúrgica provoca una inevitable lesión tisular que conduce a profundos cambios en los sistemas endocrino, metabólico y neurológico, añadidos a las alteraciones en las funciones de los distintos órganos, a consecuencia de la liberación local con acción a nivel multiorgánico de un cierto número de sustancias que participan en el proceso inflamatorio. Aunque el principal detonante de la activación del mecanismo de respuesta al estrés es el estímulo aferente desde el área quirúrgica. Numerosas sustancias humorales como citoquinas, metabolitos de la cascada del ácido araquidónico (bradiquininas, prostaglandinas, leucotrienos), óxido nítrico, endotoxinas, serotonina, histamina, sustancia $\mathrm{P}$, tromboxanos, adenosina, ADP, protones, radicales libres, y otros sistemas de cascadas biológicas así como las neurotrofinas, y el Factor de Crecimiento Nervioso (NGF) se ven envueltos, incrementándose tanto local como sistémicamente, en el perioperatorio, tanto directamente como a resultado de estas respuestas neuroendocrinas y paracrinas, y como parte de los mediadores que facilitan las respuesta inflamatoria, bien por activación directa de los nociceptores, bien por una acción indirecta a través de las células inflamatorias que a su vez liberan sustancias algógenas [29].

En años recientes se ha ido demostrando que muchos de estos factores actúan asimismo directamente sobre las células malignas, activando varios procesos moleculares críticos para la actividad metastásica tumoral, incluyendo la proliferación, adhesión, locomoción, capacidad de invasión de la matriz extracelular, resistencia a la apoptosis y secreción de factores proangiogénicos [30]. 
Por tanto, el ambiente inflamatorio facilita el aporte continuo de citoquinas, quimiocinas, enzimas y factores de crecimiento que conducen a inmunosupresión, remodelado tisular y pérdida de arquitectura tisular, apoyando la perpetuación y progresión tumoral y de las metástasis [31,32]. En este sentido se puede observar que las células neoplásicas presentan especial afinidad por los tejidos expuestos a traumatismos, observándose una mayor incidencia de recurrencias tumorales en las zonas de inserción de los trócares de las laparoscopias y/o en las zonas anastomóticas. De igual manera, no sorprende que complicaciones postoperatorias como peritonitis o dehiscencia de sutura empeoren el pronóstico del paciente al promover la recurrencia tumoral. [33-35]

Por otro lado, también se ha constatado, que a menor agresividad del trauma quirúrgico, menor proceso inflamatorio y, por tanto, mejor preservación de la función inmune perioperatoria. Con lo cual, a mayor trauma, mayor probabilidad de recurrencia tumoral. La reducción del trauma quirúrgico mediante laparoscopia en vez de laparotomía se ha asociado en algunos estudios experimentales en animales y clínicos a una disminución del crecimiento tumoral, aunque un posterior metanálisis sobre cirugía colorrectal no lo ha confirmado [36]. Además, el propio tumor induce una respuesta inflamatoria que lleva a un patrón inmunosupresivo caracterizado por células T y NK disfuncionantes.

De forma general, los cambios en respuesta al estrés se caracterizan por un incremento de las hormonas catabólicas como la GH, y un descenso de las hormonas anabólicas, con un hipermetabolismo e incremento en el trabajo cardíaco causado por una activación del sistema simpático, junto con disfunción pulmonar, náuseas, íleo, alteración del sistema de coagulación-fibrinólisis facilitando la coagulación y trombosis, además de pérdida de tejido muscular e inmunosupresión. Estos cambios forman parte del proceso de curación con el objetivo de evitar lesión de los tejidos sanos, y circunscribirse sólo a los tejidos alterados.

La cirugía se erige como uno de los más potentes activadores de la secreción de cortisol y de ACTH, pudiéndose encontrar concentraciones plasmáticas elevadas de ambas hormonas a los pocos minutos de iniciarse de la cirugía. La actividad principal de la ACTH es el estímulo de la producción de glucocorticoides, glucagón y aldosterona.

Además, los niveles de otros biomarcadores de estrés, principalmente las catecolaminas adrenalina y noradrenalina, se muestran elevados durante el periodo perioperatorio como respuesta neuroendocrina prominente a la lesión tisular y sus acompañantes: inflamación, nocicepción y dolor [29]. 
Las células tumorales e inmunes expresan receptores de catecolaminas y prostaglandinas, por lo que es razonable que respondan a la elevación de las mismas. Esto parece ocurrir por interacción con los receptores adrenérgicos beta-1 y beta- 2 expresados por las células tumorales $[37,38]$. Las catecolaminas han mostrado un incremento directo del potencial invasivo de ciertas células tumorales como las de cáncer ovárico vía adrenérgica por activación y regulación de las metaloproteinasas (MMP) y el transductor de señal y activador de la transcripción 3 (STAT-3), que contribuyen a la proliferación y supervivencia de células malignas, protegiéndolas de la apoptosis [14].

Dada la observación de que el empleo de agentes bloqueantes de los receptores beta adrenérgicos permite ralentizar o anular el efecto de las catecolaminas circulantes intraoperatorias sobre el crecimiento tumoral en estudios con animales, Neeman et al están llevando a cabo un estudio clínico en humanos para valorar el efecto del empleo de dichos beta bloqueantes sobre la recurrencia tumoral [39].

En cuanto a la inmunidad, las concentraciones plasmáticas de adrenalina están inversamente correlacionadas con la función de los linfocitos y monocitos. Actúan sobre receptores adrenérgicos localizados en la membrana de linfocitos y otras células inmunes, alterando significativamente tanto el número como la función de los linfocitos y otras células envueltas en la inmunidad contra el cáncer. Se ha demostrado que la adrenalectomía revierte estos cambios [37].

Así, las catecolaminas, al igual que otros mediadores, causan una supresión selectiva de las respuestas linfocitarias de tipo Th1. El mecanismo de inhibición de la respuesta Th1 sin acción sobre la Th2 explica el desplazamiento de la respuesta inmune hacia un predominio del tipo Th2, alterándose la respuesta inmune celular contra varios tipos de infecciones y tumores normalmente mediada por la respuesta de tipo Th1 [40].

Y no sólo eso, si no que las catecolaminas también han mostrado incrementar la producción de factores proangiogénicos como el Factor de Crecimiento Endoltelial Vascular (VEGF) en células de cáncer de ovario e influenciar la migración de múltiples líneas de células tumorales incluyendo mama, ovario y colon. [41,42]

No solo las catecolaminas sino también las prostaglandinas son liberadas localmente de forma inmediata tras el daño tisular. Muchos tumores liberan prostaglandinas, o bien reclutan macrófagos para hacerlo, presumiblemente como un mecanismo de escape del sistema inmune o bien para promocionar su vascularización. 
Así, las prostaglandinas, sobre todo PGE2, se encuentran implicadas en la promoción neoplásica y angiogénesis, como se ha visto en ratones transgénicos que sobreexpresan el receptor de PGE2 y que son más propensos a desarrollar tumores malignos de la piel. La administración de PGE2 mostró facilitar la diferenciación macrofágica hacia el fenotipo M2 protumoral, contribuyendo a la angiogénesis tumoral [43].

Las células presentadoras de antígenos (APC), como macrófagos y células dendríticas, producen principalmente PGE2. La PGE2 es generada por la acción de prostaglandina-sintetasa y la ciclooxigenasa (COX) sobre el ácido araquidónico liberado de la membrana de fosfolípidos. Una investigación sugirió que el empleo de antiinflamatorios no esteroides (AINEs), y en particular inhibidores de la ciclooxigenasa-2 (COX-2), podría reducir la incidencia de cáncer de mama. El bloqueo de la COX-2 en pacientes o animales facilitó la apoptosis tumoral y redujo los niveles de sustancias angiogénicas [44].

De forma añadida, en pacientes con cáncer de colon, la expresión de COX-2 estuvo asociada al tamaño tumoral, profundidad de invasión y presencia de metástasis ganglionar. Muy recientemente se ha relacionado el consumo habitual de aspirina con una reducción en la incidencia de melanoma [45]. Afortunadamente, en condiciones inmunes óptimas la mayoría de las células serán destruidas por el sistema inmune del huésped [46].

Para lograr la formación de metástasis a distancia, las células tumorales necesitan migrar a través de la membrana basal y matriz extracelular y extravasarse a la circulación sanguínea y/o linfática para invadir nuevos tejidos. Las MMP son enzimas cruciales tipo proteinasas que permiten al tumor permeabilizar la membrana basal mediante debilitación o desaparición de la misma por degradación, actuando a su vez sobre la matriz extracelular, facilitando la invasión y metastatización tumoral hacia los tejidos circundantes, llegando a formar nichos premetastásicos, que a su vez acabarán precisando de neoangiogénesis. Actualmente se considera que ciertos subtipos como la MMP-2 y MMP-9 juegan papeles clave en este mecanismo. De cara al crecimiento y desarrollo metastásico son importantes ciertos factores como el Factor de Crecimiento Transformante beta (TGF- $\beta$ ).

Las citoquinas liberadas por el trauma quirúrgico también regulan la secreción de las arriba comentadas MMP. Los niveles de las mismas se hallan regulados al alza en muchos tumores humanos, y están asociados con enfermedad avanzada y una menor supervivencia $[47,48]$.

Para llegar a multiplicar su potencial metastásico, los tumores precisan de un crecimiento progresivo acompañado de un aporte constante de nutrientes, inicialmen- 
te por difusión, y posteriormente a través de una red de vasos sanguíneos de nueva formación, también conocidos como neovasos. Para la neovascularización se precisará de la acción de factores proangiogénicos como el VEGF y el Factor de Crecimiento Endotelial (EGF) [24].

EI VEGF, que es el factor proangiogénico conocido de acción más importante, induce tanto la migración como la proliferación de las células endoteliales in vitro, así como la inhibición de la apoptosis endotelial. Sus efectos fisiológicos incluyen angiogénesis y linfangiogénesis con vasodilatación y aumento de la permeabilidad vascular y linfática al inducir señales paracrinas entre las células tumorales y células endoteliales, vasodilatación mediante óxido nítrico y fijación de ligandos [49].

Aunque la liberación local y sistémica de factores de crecimiento como VEGF y otros como TGF- $\beta$ y EGF durante la respuesta inflamatoria a la agresión quirúrgica debe ser considerada parte del proceso curativo, una respuesta incrementada puede promover la recurrencia tumoral tanto a nivel local como en lugares distantes [50].

Factores de crecimiento, endostatinas y otros inductores de la proliferación celular se hallaban en niveles más elevados que en sangre en los drenajes quirúrgicos en el postoperatorio de cáncer de mama [51]. Se sabe que el proangiogénico VEGF aumenta postoperatoriamente en la mayoría de los pacientes sometidos a exéresis tumoral. La concentración de esta sustancia está directamente relacionada con la cantidad de tejido dañado durante la resección del tumor y constituye un potente estímulo para la proliferación in vitro de las células del cáncer de mama.

Tanto VEGF como sus receptores se encuentran sobreexpresados en tumores malignos, como el de mama. Es un prerrequisito para el desarrollo tumoral, y está influenciado por el ciclo menstrual, siendo además un indicador pronóstico independiente [52].

Niveles elevados de VEGF han sido correlacionados con alta densidad microvascular intratumoral. Además los estudios muestran que podría transformar las células malignas con bajo potencial metastático en otras con un comportamiento más agresivo [50].

Se ha observado que la aparición de complicaciones postoperatorias, como infección peritoneal, lógicamente asociada a un aumento de la respuesta inflamatoria, está relacionada con la aparición de recaída tumoral con aumento de angiogénesis y 
VEGF. En este sentido, la aparición de abscesos intraabdominales postoperatorios en cirugía de cáncer de colon y de infecciones postoperatorias de la herida en laringuectomía oncológica está asociada con un aumento de las recurrencias locales y de la mortalidad, al igual que ocurre cuando aparece dehiscencia de sutura [33-35].

Por el contrario, factores como la endostatina y la angiostatina, de carácter antiangiogénico, pueden verse seriamente reducidos a causa de la cirugía. La extirpación tumoral puede eliminar un mecanismo antiangiogénico principal en el que el tumor primario que puede inhibir por sí mismo la angiogénesis, ya que se trata del principal agente liberador de sustancias antiangiogénicas. Esto puede conducir a la promoción de la supervivencia y crecimiento de la citada Enfermedad Mínima Residual [20].

El dolor, definido como una experiencia sensorial y emocional desagradable asociada con una lesión real o potencial o descrita en términos de la misma, aparece, en el contexto quirúrgico, a consecuencia del daño tisular. Los estímulos dolorosos actúan liberando la sustancia $\mathbf{P}$ de las fibras $\mathbf{C}$, despolarizando a las neuronas del asta dorsal. La sustancia P se involucra en la transmisión del dolor y la inflamación neurogénica, uniéndose al receptor de la neurokinina-1 o NK-1. Tanto los antagonistas de los receptores de neurokinina como los de la sustancia $\mathrm{P}$ actúan como analgésicos, inhibiendo la respuesta al dolor. De hecho, la administración de anestésicos locales, como en la analgesia regional, inhibe la liberación de sustancia $\mathrm{P}$, de forma no competitiva.

La reacción ante el dolor intra y postoperatorio se manifiesta, por un incremento de la secreción de ACTH (Hormona corticotropa), de GH (Hormona del crecimiento), de ADH (Hormona antidiurética) y de prolactina, además de potenciar el ya estimulado eje hipotálamo-hipofisario y el sistema nervioso simpático, viéndose implicado en la promoción de la inmunosupresión y la promoción/recurrencia tumoral. El dolor amplifica y potencia los efectos deletéreos de las respuestas metabólicas arriba descritas, reflejos autonómicos, náusea, íleo y espasmo muscular, retrasando, así, la restauración de la función.

Se ha demostrado que las células tumorales mamarias expresan y liberan mayor cantidad de sustancia $\mathrm{P}$ que las células normales, además de observarse receptores de sustancia P y de NK-1, en tejidos tumorales, como el cáncer de mama, pudiendo así actuar de forma autocrina. Y al haberse observado inducción de mitogénesis en células tumorales tras la unión al receptor de Neurokinina-1, teniendo además un efecto angiogénico, al igual que inductor de la migración celular, en células MDA-MB-468 de carcinoma mamario, la sustancia $\mathrm{P}$ puede contribuir perioperatoriamente al incremento del tamaño tumoral, al igual que a su diseminación. 
En este sentido, además, los antagonistas de los receptores NK-1 han mostrado actividad antitumoral a través de la inhibición de la proliferación celular sobre varias líneas celulares tumorales, incluyendo el cáncer de mama mediante muerte celular y apoptosis, inhibición de la neoangiogénesis tumoral y migración celular así como bloqueo de la acción mitogénica de la sustancia P sobre dichas células malignas [54].

Por tanto, no es sorprendente, que el alivio del dolor se haya mostrado limitador del aumento de la susceptibilidad metastásica inducido por la cirugía en animales, al atenuar la inmunosupresión intra y postoperatoria. En seres humanos todavía no hay estudios que hayan analizado esta relación, únicamente se ha constatado el efecto protector del alivio eficaz del dolor para atenuar la inmunosupresión. El tratamiento óptimo del dolor postoperatorio es, por tanto, mandatario para potenciar la recuperación y reducir la morbi-mortalidad. Con todos estos datos, el manejo del dolor se antoja de particular importancia en el paciente sometido a cirugía oncológica.

\subsubsection{Anestesia y cáncer}

Inevitablemente asociados a los procedimientos quirúrgicos los fármacos y técnicas anestésicas han sido demostrados agentes modificadores del curso evolutivo oncológico con mayor o menor acierto.

\subsubsection{Hipnóticos y cáncer}

La anestesia general es una condición reversible, inducida por fármacos que aportan amnesia, analgesia, inmovilidad y control de las respuestas autonómicas durante los procedimientos quirúrgicos. Aunque la anestesia intravenosa total se ha desarrollado rápidamente en los últimos años, la anestesia balanceada con agentes volátiles halogenados continúa siendo empleada en la mayoría de los procedimientos bajo anestesia general.

Los agentes anestésicos generales han sido repetidamente implicados en la progresión tumoral tanto por efecto directo sobre las células tumorales como por inducir inmunosupresión, contribuyendo, de esta manera, a los efectos deletéreos del periodo perioperatorio junto con la cirugía.

En los últimos años, los hallazgos de diferentes estudios, fundamentalmente de laboratorio, apoyan la hipótesis de que, en virtud de algunos mecanismos aún desconocidos, el manejo anestésico puede influir en el proceso fisiológico y fisiopatológico celular y/o molecular, como la proliferación, angiogénesis, migración y apoptosis, y que ésta 
es una posible explicación de su posible participación en el desarrollo de tumores, así como en la recurrencia tumoral, reduciendo la tasa de supervivencia de los pacientes. Sin embargo, el posible papel de los fármacos anestésicos en el desarrollo y progresión de la enfermedad oncológica aún no está totalmente claro. Se encuentra abierta, por tanto, una prometedora línea de investigación para determinar el papel de los anestésicos generales sobre el curso de la enfermedad oncológica de los pacientes sometidos a cirugía de resección tumoral.

En la siguiente revisión nos detendremos en los fármacos que más interesan al objetivo del presente trabajo.

\subsection{Anestésicos halogenados}

Representan, en conjunto, los fármacos más empleados en su ámbito desde hace varias décadas, pudiendo utilizarse bien aisladamente o como parte de una anestesia balanceada. La interacción que estos medicamentos ejercen con el cáncer también ha sido estudiada, sobre todo, tras situarse bajo la sospecha de inducción tumoral, de abortos espontáneos y anomalías congénitas, principalmente en la exposición crónica del personal de quirófano. Estas hipótesis, sin embargo, no se han verificado en los primeros estudios en animales ni en los estudios epidemiológicos sobre los efectos de dicha exposición crónica a concentraciones subanestésicas. En los últimos años ha sido la exposición aguda la que ha despertado el mayor interés, sobre todo en el paciente quirúrgico oncológico.

\section{A. Desflurano}

Múltiples datos preclínicos y clínicos demuestran que los fármacos halogenados empleados para la anestesia general son capaces de alterar la respuesta inmune [55]. Y no sólo eso, sino que presentan acciones directas sobre las células tumorales, más en concreto, son capaces de modificar, de forma tiempo-dependiente, la expresión genética de moléculas implicadas en las distintas fases del desarrollo y progresión tumoral en tumores de mama y cerebral, y otras funciones celulares con posibles consecuencias clínicas, aún desconocidas.

Así, se han identificado varios genes que pueden predecir la supervivencia del cáncer de mama. La expresión genética se emplea para la estratificación del riesgo, clasificación de la enfermedad, y predicción del desenlace en los pacientes oncológicos, entre ellos, pacientes con cáncer de mama, pudiendo usarse para guiar el tratamiento en mujeres con cáncer de mama avanzado. 
Todos los anestésicos volátiles modulan la expresión genética del tumor mamario MCF-7 y del tumor neuronal SH-SY5Y de una forma dependiente del tiempo. El desflurano, al igual que sevoflurano e isoflurano aumentó y mantuvo la expresión de los genes tumorales de MCF-7 a lo largo del tiempo de administración de los mismos. Mientras, la respuesta a los anestésicos más antiguos, enflurano y halotano, fue doble: inicialmente, aumentó los niveles de expresión para después disminuir los mismos. Sin embargo, en células SH-SY5Y ambos grupos de anestésicos inhalatorios tuvieron el mismo efecto, un incremento de los niveles de expresión con el tiempo de exposición [56].

El precondicionamiento con desflurano y con sevoflurano a concentraciones clínicamente relevantes redujo la liberación de MMP-9 desde los neutrófilos humanos en un modelo in vitro de lesión por reperfusión, a la vez que reduce la invasividad de las células tumorales a través de la matriz extracelular. Pero podría tener otros efectos si se administra durante más tiempo [47].

\section{B. Halotano}

Katzav et al demostraron hace más de dos décadas que el halotano, utilizado durante la cirugía de extirpación tumoral en ratones portadores de carcinoma pulmonar del tumor de Lewis (3LL), disminuye la actividad de las células asesinas naturales (NK), acelerando el crecimiento postoperatorio de la metástasis tumoral [57].

Aunque su efecto no alcanzó significación estadística, este fármaco, al igual que otros anestésicos como ketamina y tiopental, hizo reducir el número de las células NK circulantes por milímetro cúbico de sangre en ratas y aumentó las metástasis pulmonares o bien la retención pulmonar de células MADB106 (un línea variante seleccionada de células obtenidas a partir de una metástasis pulmonar de un adenocarcinoma mamario - MADB100 - inducida químicamente en ratas) en otro trabajo. Sin embargo, la adición del bloqueo espinal a la anestesia general con halotano atenuó notablemente (en un $70 \%$ ) la promoción de metástasis durante la cirugía [58].

En 1994, Waxler et al, investigaron los efectos de este agente volátil sobre el contenido de inhibidor de la proteasa tisular pulmonar y sobre el comportamiento del tumor en los pulmones de ratones. Demostraron cómo la estimulación de la actividad inhibidora de las proteinasas por halotano puede ser responsable, en cambio, de la inhibición de la proliferación de células tumorales, llevando a menores nódulos tumorales aunque no tuvo ningún efecto sobre la colonización [59]. 
En los últimos años, en su estudio in vitro con el halotano, sevoflurano e isoflurano, Kvolik et al han observado cómo, en el ámbito clínico, el halotano tiene una potencia antitumoral superior en comparación con el isoflurano. En particular, el halotano suprimió en mayor medida el crecimiento de las células de carcinoma de laringe Hep-2 (hasta un $67,7 \%$ respecto al control), de las células de carcinoma de colon Caco-2 (hasta un $76,3 \%$ ), y de células pobremente diferenciadas de metástasis ganglionares de carcinoma de colon SW620 (hasta un 80,9\%), mientras que fue mínimo en los fibroblastos normales (hasta el $89,4 \%$ del control) [60].

\section{Enflurano}

En un estudio clínico, se comparó la actividad de las células NK en pacientes sometidos a cirugía oftalmológica con anestesia basada en enflurano/óxido nitroso/ oxígeno, droperidol/fentanilo/óxido nitroso/oxígeno o droperidol/ketamina/ fentanilo/oxígeno. En el primer día postoperatorio, la anestesia en el grupo de enflurano, pero no en los otros grupos, se asoció con una disminución de la actividad de las células NK, lo que indica que, en comparación con la anestesia intravenosa, los anestésicos volátiles pueden ser especialmente supresores de las células NK [61].

\section{Isoflurano}

La exposición al isoflurano (30 minutos al 1,2\%) evitó en un trabajo la apoptosis de células tumorales in vitro, protegiendo al cáncer de colon humano, a través de la vía de las caveolinas [62].

En este mismo sentido, Jun et al encontraron evidencias in vitro acerca de que el empleo de anestesia combinada con isoflurano no es apropiada para pacientes con tumores de cabeza y cuello. Así, en su trabajo, el isoflurano al $2 \%$ aumentó la proliferación e invasión de células de células de carcinoma escamoso de cabeza y cuello tras exposición única (durante 3 ó 6 horas) a dicho agente anestésico e inhibió la apoptosis de las mismas. Los autores recomendaron como primera elección la anestesia intravenosa total para este tipo de pacientes durante la cirugía de exéresis [63].

Moudil y Singal encontraron que isoflurano potencia la proliferación de melanoma de igual manera que halotano [64]. Por otra parte, según el estudio in vitro de Mitsuhata y colaboradores, isoflurano, al igual que sevoflurano, es capaz de alterar la liberación de citoquinas por NK y las células NK-like en respuesta a las células tumorales [65]. 
De acuerdo con estos resultados, Ke et al, también muestran que, durante la colecistectomía abierta, la anestesia intravenosa total con propofol y remifentanilo, suprime la respuesta inflamatoria causada por la cirugía en mayor proporción que una técnica inhalatoria balanceada con isoflurano. Los niveles plasmáticos de TNF-alfa, la interleuquina IL-6 (IL-6) y la IL-10, medido al final de la anestesia y la cirugía, son significativamente mayores cuando se utiliza este agente [66].

Ren et al encontraron que el propofol potenciaba la diferenciación de linfocitos Th1 frente a los Th2, en cirugía de lobectomía por cáncer de pulmón. Así, la preservación del cociente Th1/Th2 se mantuvo favorable con el propofol frente a isoflurano que no tuvo ningún efecto [67].

Varios anestésicos volátiles, incluidos isoflurano y desflurano, han mostrado activar directamente Factores Inducibles por Hipoxia (HIF) en las células tumorales, incrementando su resistencia a la muerte celular bajo estrés hipóxico, parcialmente al inducir la secreción de VEGF y otras factores angiogénicos [68].

\section{E. Sevoflurano}

En 2011 Ecimovic et al observaron que el sevoflurano favorecía un aumento en la invasión y migración de las células tumorales de cáncer de mama MCF-7 (aumento del 29-47 \% y $58 \%$ ) y MDA-MB-231 (9-24 \% y $63 \%$ ), mientras que sólo aumentó su proliferación (5-26 \%) en las células MDA-MB-231 [69].

Como se comentó anteriormente, al igual que otros agentes anestésicos inhalatorios, el sevoflurano fue capaz de modular la expresión de genes implicados en la biología tumoral, aunque aún se desconoce cuáles son sus consecuencias [56].

Asimismo, este agente es capaz de de alterar significativamente la liberación de las citoquinas de células NK y NK-like como respuesta contra las células tumorales, atenuando la liberación de la interleuquina-1beta (IL-1beta) y TNF-a, aunque no tuvo efecto sobre la IL-2 [65]. El sevoflurano, a través de la unión a antígenos linfocitarios, interfiere con la función de los linfocitos [70].

Por el contrario, se ha encontrado que disminuye in vitro la invasión y migración de células de cáncer de laringe, de colon y de pulmón (en este caso también indujo apoptosis de las células) $[60,71,72]$. 
Al igual que con desflurano, el precondicionamiento a concentraciones relevantes con sevoflurano redujo la liberación de MMP-9 desde neutrófilos humanos modulando la invasividad facilitada por los neutrófilos de las células MC-38GFP de cáncer de colon a través de la matriz extracelular [47].

Además, recientemente, un amplio estudio prospectivo de cohortes puso de relieve que no tenía ningún impacto sobre la incidencia de cáncer, en pacientes sin diagnóstico previo del mismo, someterse a una intervención quirúrgica bajo anestesia general con sevoflurano con registros de valores de índice biespectral o BIS por debajo de 45, medida a los 5 años de dicha intervención quirúrgica [73].

\subsection{Propofol}

En estudios en animales, el propofol puede modular la respuesta inmune dirigida hacia la supresión tumoral. Por ejemplo, la actividad de las células Natural Killer circulantes no se vio afectada en un estudio por la utilización de propofol, mientras que fue significativamente reducida por la ketamina, el tiopental y halotano. De forma consistente con estos resultados, en el mismo trabajo la retención pulmonar y metástasis de células tumorales MADB106 de adenocarcinoma mamario no fueron afectadas por el empleo de propofol, mientras que fueron importantes con los otros tres agentes anestésicos mencionados [58].

Con el fin de examinar la propiedad antitumoral del propofol in vivo, se ha investigado la evolución de las metástasis pulmonares tras la inoculación de células de osteosarcoma murino en la espalda de ratones. La infusión continua de propofol en la cavidad peritoneal mediante una bomba osmótica disminuyó significativamente el número de nódulos pulmonares metastáticos sin que se afectara el crecimiento del tumor en el lugar de la inoculación [74].

El propofol suprimió directamente la viabilidad, proliferación e invasividad de ciertas líneas de células tumorales. De esta manera, por ejemplo, en humanos el empleo de propofol dio lugar a apoptosis de células HL-60 de leucemia promielocítica [75].

En las células carcinoma de colon humano (LOVO), el empleo de propofol disminuyó significativamente la expresión de metaloproteinasas de matriz 2 (MMP-2) y metaloproteinasas de matriz 9 (MMP-9), llevando a una disminución de la actividad invasiva de las células tumorales [76]. 
En otra investigación, el propofol suprimió la migración de varias líneas celulares humanas, incluyendo las células de carcinoma cervical Hela, células HT1080 de fibrosarcoma, células HOS de osteosarcoma humano, y células RPMI-7951 de melanoma. Cuando las células HeLa fueron tratadas con propofol, la formación de las fibras de estrés de actina, así como las adhesiones focales fueron inhibidas mediante la modulación de Rho A, lo que puede explicar la disminución de la migración. Aunque debe enfatizarse que este modelo animal no es clínicamente relevante en términos de dosificación y duración de la administración [73].

Las células dendríticas, con un papel fundamental en la inmunidad antitumoral, procedentes de médula ósea se utilizaron como vacuna en presencia de propofol para examinar su eficacia contra el crecimiento de células B16 de melanoma tras su inoculación en ratones. La vacuna tratada con propofol fue más eficaz a la hora de retrasar el crecimiento del tumor. Además, la actividad de las células NK tanto contra las células de melanoma B16 como contra las células YAC-1 (una línea celular altamente sensible a las células NK) fue mayor en los sujetos que recibieron la vacuna tratada con propofol. Por lo tanto, en este modelo animal, el propofol parece ser capaz de regular al alza la actividad de las células NK mediante la diferenciación de células dendríticas para ser eficientes en la comunicación células dendríticas-Natural Killer [77].

Además, el propofol presenta un alto potencial como antioxidante eficiente en anestesia clínica: la administración de este agente previene del estrés oxidativo, la activación del Factor Nuclear kappa B (NF-kB) y la sobreexpresión de la sintasa de óxido nítrico (iNOS) en células de ratas que recibieron halotano. Así, el tratamiento con propofol podría bloquear la producción de mediadores nocivos envueltos en el desarrollo de lesiones inducidas por halotano [78].

Finalmente, en un estudio clínico, durante colecistectomía abierta, la anestesia intravenosa total con propofol y remifentanilo parece suprimir la respuesta inflamatoria provocada por la cirugía en mayor medida que la técnica inhalatoria balanceada con isoflurano: los niveles plasmáticos de TNF-a, IL-6 e IL-10, medidos al finalizar la intervención anestésica y quirúrgica, fueron significativamente menores en el grupo de propofol/remifentanilo que en el grupo tratado con isoflurano [66] .

Por el contrario, se han observado diferentes pautas en las células MDA-MB-468 de carcinoma mamario que responden a los anestésicos no volátiles, como el propofol, con un incremento en su migración. La activación de los receptores GABA-A por el propofol determina, de hecho, que la migración de las células MDA-MB-468 (64,4 \pm 7 $\%)$ incremente significativamente hasta el $85.0 \pm 5.0 \%$ [79]. 


\subsubsection{Opioides y cáncer}

Los opioides constituyen un grupo de fármacos que poseen afinidad selectiva por los receptores opioides. Son sustancias derivadas del opio, poseen una gran potencia analgésica, usándose ampliamente en el manejo del dolor. En general, son altamente efectivos y bien tolerados, lo que les convierte en idóneos para su uso clínico de rutina.

\subsection{Mecanismo de acción}

Los efectos antinociceptivos de estos fármacos están mediados a través de los receptores opioides, distribuidos por el sistema nervioso central (SNC) y periférico (SNP), encontrándose también en el sistema inmune, donde sus funciones aún no han sido esclarecidas.

Los receptores opioides más conocidos son mu, kappa, delta y sigma. Su distribución y concentración no son uniformes, no teniendo relación la densidad de los mismos en una zona determinada con su potencia analgésica cuando son activados. En el SNC se distribuyen desde la corteza cerebral, sistema límbico, hipotálamo, tálamo, región bulboprotuberancial, áreas extrapiramidales y sustancia gelatinosa, hasta las neuronas simpáticas preganglionares. Los receptores opiáceos medulares están situados principalmente en las láminas superficiales de la médula, I (zona marginal de Waldeyer) y II (sustancia gelatinosa), estando presentes en menor número en las láminas más profundas.

En el SNP se encuentran localizados en el plexo mioentérico y submucoso, vejiga urinaria y conductos deferentes. También se han hallado receptores en las terminaciones de los nervios periféricos que son al parecer los responsables del procesamiento del dolor en el área de la inflamación.

La acción analgésica de los opioides es debida a la interacción con estos receptores situados a nivel presináptico y postsináptico. Es su propiedad terapeútica más importante, en estrecha relación a la dosis empleada. Ocasionan efectos psicológicos de características e intensidad variables y fármacodependencia. 


\subsection{Clasificación}

Tabla II. Tipos de receptores opioides

\begin{tabular}{|l|l|l|l|l|}
\hline Tipo acción & Receptor & $\begin{array}{l}\text { Actividad } \\
\text { intrínseca }\end{array}$ & Ejemplo & \\
\hline $\begin{array}{l}\text { Agonista } \\
\text { puro }\end{array}$ & mu & Máxima & $\begin{array}{l}\text { Morfina, } \\
\text { fentanilo }\end{array}$ & \\
\hline $\begin{array}{l}\text { Agonista } \\
\text { parcial }\end{array}$ & $\begin{array}{l}\text { Inferior a } \\
\text { máxima }\end{array}$ & Buprenorfina & Nalorfina & $\begin{array}{l}\text { En presencia } \\
\text { de agonista } \\
\text { puro son } \\
\text { antagonistas }\end{array}$ \\
\hline $\begin{array}{l}\text { Agonista - } \\
\text { antagonista }\end{array}$ & $\begin{array}{l}\text { Kappa - } \\
\text { agonista } \\
\text { mu }\end{array}$ & No tiene & Naloxona & \\
\hline $\begin{array}{l}\text { Antagonista } \\
\text { puro }\end{array}$ & & & & \\
\hline
\end{tabular}

\subsection{Morfina}

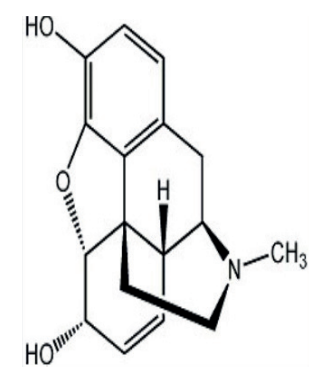

Figura 6. Molécula de morfina

Se trata de un alcaloide fenantrénico extraído del jugo del opio, producido por la planta Papaver somniferum, que actúa como agonista puro sobre los mencionados receptores mu, lambda y kappa. Es muy eficaz cuando se administra correctamente, tanto en dolor crónico como en dolor agudo, carece de techo terapéutico y se absorbe adecuadamente por todas las vías a excepción de la transdérmica. La dosis y vía de administración deben ajustarse individualmente. Potencialmente, es capaz de liberar histamina. 
Su empleo está indicado en el dolor agudo (por ejemplo, perioperatorio), en el dolor crónico neoplásico y en muchos casos de dolor crónico no oncológico, cuando la intensidad del mismo sea intensa o muy intensa, lo que corresponde al escalón tres de la escala analgésica de la Organización Mundial de la Salud (OMS) [80,5].

Sin embargo, en los últimos años se está tomando conciencia de la posible repercusión del empleo de morfina en los pacientes sometidos a cirugía oncológica, pues parece tener un papel destacado en la mala evolución tumoral. Las preocupaciones acerca de la posible promoción del crecimiento tumoral y metástasis por parte de la morfina están principalmente originadas por el hecho de que los opioides, incluida la morfina, tienen efectos inmunosupresores bien establecidos, comprometiendo la función inmune celular y humoral, y, por tanto, la defensa del huésped contra los tumores malignos. Recientemente se ha demostrado, además, que la morfina incrementa la angiogénesis, manteniendo el crecimiento tumoral en un modelo murino de cáncer de mama. Más aún, los opioides, al activar los receptores de VEGF, no sólo inducen angiogénesis sino también permeabilidad vascular, y la activación de los receptores opioides potencia la proliferación e invasión de células tumorales pulmonares [81-89].

Estas hipótesis fueron planteadas tras los resultados de sendos estudios clínicos que, aunque retrospectivos, mostraron que cuando se empleaba anestesia regional (paravertebral o epidural) en pacientes sometidos respectivamente a cirugía de cáncer de mama o de próstata, la tasa de recurrencia del cáncer y/o las metástasis fueron significativamente menores que en los pacientes que recibieron anestesia general con analgesia opioide mediante morfina. El periodo de seguimiento fue de 2,5 - 4 años en el caso del cáncer de mama [90] y de 2,8 - 12,8 años en el estudio de cáncer de próstata [91]. Una de las hipótesis propuestas para explicar estos resultados ha envuelto el efecto reductor de la necesidad de opioides perioperatorios por parte de la anestesia/analgesia regional, y el asumir que la morfina podría ser al menos en parte responsable de la alta tasa de recurrencia y mortalidad en los grupos de anestesia general, que recibieron analgesia opioide. Posteriormente, múltiples estudios retrospectivos en éstos y otros tipos tumorales como colónico, rectal, renal y ovárico.

Adicionalmente, se ha observado que el empleo agudo y/o de bajas dosis de morfina parece promover el crecimiento tumoral [92] al contrario de lo que parece suceder con su uso de forma crónica a altas dosis [93]. Reforzándolo, en 2012 un estudio en más de 2.039 mujeres con cáncer de mama encontró una supervivencia a 10 años significativamente mayor de lo esperado, además de una respuesta analgésica reducida a los opioides, en aquellas que presentaban un polimorfismo del gen del receptor opioide mu (A118G) [94]. De igual manera, en otro trabajo este mismo polimorfismo se encontró asociado a carcinoma escamoso esofágico [95]. 
A pesar de la clara evidencia de inmunosupresión inducida por opioides, aún persiste una evidencia in vivo insuficiente de que la progresión tumoral se encuentra influenciada por este mecanismo. Sin embargo, se ha sugerido el uso de anestesia regional, siempre que sea posible.

Mientras es legítimo cuestionarse si la morfina debe ser evitada durante la cirugía oncológica, debe recordarse que los efectos promotores tumorales demostrados de los opioides están equilibrados con su potencial antitumoral, documentado también a varios niveles. La morfina se ha mostrado poseedora de efectos antiproliferativos directos y proapoptóticos en diferentes tipos de células tumorales. Más aún, varios estudios con células endoteliales, y ensayos in vivo, han demostrado efectos angiostáticos de la morfina. Sin embargo, no hay estudios clínicos demostrando los efectos de la morfina per se en el crecimiento tumoral, recurrencia o metástasis $[96,97]$.

El manejo postoperatorio del dolor es de gran importancia especialmente en pacientes con cáncer. El fallo en el correcto control del dolor postoperatorio lleva a una respuesta inflamatoria exarcebada, a la par que prolongada, que incrementa el riesgo de dispersión tumoral en el periodo perioperatorio. La elevada eficacia analgésica de los opioides se ha mostrado como beneficiosa en la reducción del estrés quirúrgico. Así, si la analgesia morfínica debe evitarse en el periodo perioperatorio en pacientes oncológicos, deben adoptarse imperativamente estrategias alternativas eficaces para controlar el dolor postoperatorio. Éstas incluyen el empleo de anestesia regional, la coadministración de antagonistas periféricos opioides junto con la morfina y otras posibles intervenciones analgésicas alternativas.

Considerando la posibilidad de que la morfina pueda tener efectos directos sobre el crecimiento tumoral, opuestos a los generados por la ablación central de la respuesta de estrés, la coadministración de antagonistas opioides periféricos capaces de revertir los efectos periféricos indeseables de la morfina sin afectar sus efectos analgésicos centrales podría constituir una atractiva opción.

La metilnaltrexona es un antagonista opioide que no cruza la barrera hematoencefálica, preservándose la analgesia mediada por el SNC. Durante los ensayos con su uso compasivo para tratar el íleo opioide en pacientes con cáncer avanzado en la Universidad de Chicago, los investigadores observaron varios casos de supervivencia más allá de lo biológicamente esperado, lo que despertó el interés en los efectos directos de los opioides en la progresión tumoral [98].

Esta hipótesis ha sido comprobada en diversos escenarios experimentales. Un estudio in vitro mostró que el pretratamiento de células endoteliales humanas cultiva- 
das con metilnaltrexona revertía los efectos de proliferación y migración causados por la morfina y otros agonistas opioides. La evidencia in vitro e in vivo fue documentada mostrando que la metilnaltrexona inhibe la rotura de la barrera celular endotelial y el incremento de la permeabilidad vascular inducido por los agonistas mu opioides. Como resultado, se han propuesto potenciales aplicaciones terapéuticas de la metilnaltrexona sobre el control de la angiogénesis tumoral. La metilnaltrexona además ha mostrado efectos sinérgicos con el efecto antiangiogénico de los fármacos antitumorales bevacizumab, 5-fluorouracilo, rapamicina y temsirolimus [99-100]. Los resultados han demostrado la involucración de receptores mu opioides en la proliferación y migración de las células tumorales pulmonares. La naltrexona al igual que la eliminación mediante ingeniería genética de los receptores mu opioides (conocido como MOR knockdown) atenuó el crecimiento e invasión tumoral maligna primaria y metastásica en ratones tras la inyección de las células malignas [89]. Más aún, el antagonista opioide naloxona descendió la proliferación inducida por 17-betaestradiol de células de cáncer de mama MCF-7 en un $65 \%$, debido al antagonismo tanto del receptor mu opioide como de los receptores estrogénicos [101]. Actualmente, se está Ilevando a cabo un ensayo clínico en fase II, reclutando sujetos para estudiar el posible efecto antitumoral de la naltrexona, en cáncer de mama estrógeno dependiente (NCT00379197) [102] y en gliomas (NCT01303835) [103].

El uso potencial de antagonistas opioides en el contexto del cáncer es debatible en vista de la literatura contrapuesta: un estudio clínico retrospectivo en pacientes bajo tratamiento de mantenimiento con metadona no pudo mostrar ventaja alguna de la naltrexona frente a la metadona en cuanto a la formación de nuevos tumores. En otro trabajo, la naltrexona incluso incrementó la proliferación in vitro de células de cáncer de colon, páncreas, y de cabeza y cuello. Se ha sugerido que este efecto podría ser debido al antagonismo del efecto inhibitorio del crecimiento del opioide endógeno metencefalina [104]. Un estudio de angiogénesis durante la colestasis mostró que la naltrexona promovía la angiogénesis en el tejido hepático [105]. Estudios más grandes, incluyendo ensayos clínicos randomizados, aportarán luz sobre si los antagonistas opioides periféricos mejoran la supervivencia libre de cáncer cuando se añaden a la analgesia opioide tras la cirugía oncológica.

\subsubsection{Analgesia regional y cáncer}

La analgesia regional recurre a la inyección de pequeñas cantidades de anestésicos locales en regiones anatómicas específicas, con el objetivo de bloquear la conducción nerviosa periférica o espinal (neuroaxial, paravertebral). Este abordaje previene de forma eficiente la nocicepción y el dolor, mientras, y a diferencia de la anestesia general, bloquea la transmisión nerviosa hacia los núcleos del Sistema Nervioso Central que, de otra forma, iniciarían las respuestas simpáticas y del eje hipotálamo-hipofisario. 
La analgesia regional puede ser utilizada con el fin de aportar un adecuado control del dolor durante y tras una amplia variedad de procedimientos incluyendo mastectomías, toracotomías, cirugía abdominal así como procedimientos de las extremidades superiores e inferiores [106].

La anestesia general envuelve una fase de inducción (con propofol, por ejemplo), y una de mantenimiento, generalmente con un anestésico volátil, combinado con el uso de analgésicos para el alivio del dolor intra y postoperatorio, comúnmente, opioides.

\subsection{Analgesia regional y recurrencia tumoral}

En los últimos años, se ha despertado un creciente interés acerca de los efectos a largo plazo sobre la recurrencia tumoral y la aparición de metástasis, que podría tener el empleo de determinados tipos de analgesia frente a otros en pacientes sometidos a cirugía oncológica. Más concretamente, parece que el empleo de analgesia mediante bloqueo farmacológico de la transmisión nerviosa con anestésicos locales o anestesia regional, tanto de forma combinada con anestesia general como aisladamente, podría proteger en cierta medida de la aparición temprana de metástasis o bien de recurrencia tumoral. Este efecto protector parece ser posible a través de bloqueos nerviosos tanto a nivel neuroaxial como a nivel periférico.

Una de las hipótesis propuestas para explicar, al menos en parte, estos efectos consiste en que la analgesia regional atenúa y previene cada uno de los propuestos efectos adversos protumorales perioperatorios que potencian la inmunosupresión y progresión tumoral, como ha mostrado en diferentes estudios, al atenuar la respuesta neuroendocrina al estrés quirúrgico bloqueando las vías de transmisión neuronal aferente y previniendo que Ilegue al Sistema Nervioso Central, donde activaría dicha actividad neuroendocrina, y bloqueando la sobreactivación del eje hipotálamo-hipofisario y del sistema nervioso simpático eferente, así como la inflamación. De esta manera, también se va a encontrar reducida o incluso eliminada la necesidad de agentes como los anestésicos volátiles o de analgésicos opioides, implicados ambos, aunque con resultados a veces contradictorios, en la promoción tumoral, como se vio anteriormente $[107,108]$.

Fueron estudios animales los que, inicialmente, apuntaron a las diferencias entre ambos abordajes analgésicos como las potenciales contribuyentes al desfavorable pronóstico observado en los pacientes sujetos a anestesia general junto con analgesia opioide. 
De esta manera, Bar-Yosef y colaboradores llevaron a cabo una investigación en 2001 en un modelo animal, más concretamente en ratas, observando que la adición de bloqueo espinal a la anestesia general con halotano llegaba a atenuar hasta en un $70 \%$ la promoción de metástasis durante la cirugía. Las ratas habían sido previamente inoculadas con células MADB106 de adenocarcinoma mamario, que metastatizan específicamente en pulmón, y se caracterizan por ser altamente sensibles a la acción de las células de defensa Natural Killer. La actividad de las células Natural Killer, que también fue cuantificada, fue reducida en la misma medida en el grupo de anestesia general y en el de cirugía, pero esta reducción fue atenuada por el bloqueo espinal [109].

En humanos también han sido varios los estudios que han mostrado una mejora en el pronóstico de los pacientes sometidos a anestesia regional frente a los que recibieron analgesia opioide. En el año 2.000, Schlagenhauff et al en su estudio retrospectivo multicéntrico ya hablan de impacto pronóstico según el tipo de anestesia empleado, en este caso durante la excisión de melanoma cutáneo primario. Revisaron los casos y datos registrados de 4.329 pacientes diagnosticados y tratados entre 1976 y 1986 en el Servicio de Dermatología de una docena de hospitales alemanes. Los pacientes evaluados fueron aquellos sometidos a anestesia general o bien a anestesia local. Aquellos que recibieron anestesia peridural o espinal no fueron incluidos debido al bajo número de casos. Fueron sometidos a seguimiento cada 3 a 6 meses durante al menos 10 años, excepto negativa o fallecimiento del paciente. Los resultados obtenidos fueron que, además de otros factores ya conocidos, la anestesia general también constituía un factor pronóstico independiente de menor supervivencia. Con el fin de evitar posibles sesgos, restringieron la inclusión de pacientes al período 1976-1986, cuando la elección del tipo anestésico dependía principalmente del centro hospitalario. Destacaron que la presencia de ulceración, regresión o un determinado tamaño tumoral podrían haber influido en la elección del tipo de anestesia. Los autores concluyen que la anestesia general debe ser empleada con precaución, y que debe preferirse la extirpación del melanoma bajo anestesia local, sobre todo, habiéndose reducido en los últimos años los márgenes de seguridad necesarios [110].

Basados en su análisis retrospectivo, Exadaktylos y colaboradores, en 2006, sugirieron que el empleo de analgoanestesia regional mediante bloqueo paravertebral para cirugía de cáncer de mama podía reducir el riesgo de recurrencia o metástasis en los años posteriores. Habían valorado retrospectivamente las historias médicas de 129 pacientes que fueron sometidas a mastectomía y linfadenectomía axilar. 79 recibieron anestesia general mientras $\mathbf{5 0}$ se sometieron a anestesia paravertebral en combinación con anestesia general. La supervivencia libre de recurrencia y metástasis fue del $94 \%$ en el grupo paravertebral comparado con el $82 \%$ a los 24 meses y $77 \%$ a los 36 meses del grupo de anestesia general [90]. 


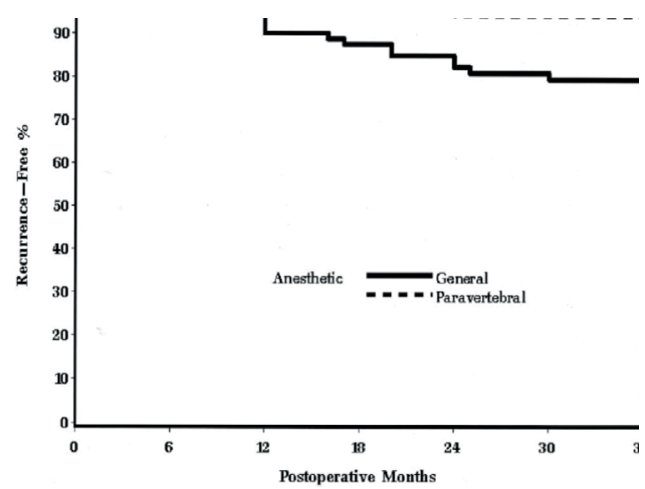

Figura 7. Asociación entre bloqueo paravertebral y recurrencia oncológica (Exadaktylos et al [90])

En otras estirpes tumorales también se han llevado a cabo sucesivos estudios retrospectivos, con resultados en ocasiones divergentes en los mismos tipos tumorales. Así, Biki et al observaron que aquellos que recibieron anestesia general combinada con analgesia epidural para prostatecomía radical tenían un $57 \%$ menos de riesgo de recurrencia de cáncer frente a aquellos que recibieron anestesia general con opioides para analgesia postoperatoria. Por el contrario, otros dos grupos de autores no encontraron tales diferencias, si bien es cierto que tampoco empeoró el pronóstico [111].

En cáncer de ovario, se observó un beneficio clínico con el empleo de analgesia epidural en la mayoría de los trabajos, si bien en uno se observó un beneficio específico únicamente en aquellas pacientes con tumores más avanzados [112], y otro no pudo mostrar un claro impacto en cirugía de citorreducción [113].

A su vez, trabajos más pequeños han valorado el empleo de analgesia regional en tumores menos habituales y más dispares como el cáncer de cabeza y cuello [114], y en biopsias de ganglio centinela para melanoma [115] y cáncer de mama [116], hallando todos ellos un beneficio significativo en términos de recurrencia y pronóstico.

El subtipo tumoral específico podría estar detrás de los resultados en varios estudios, como en el de Lai et al en carcinoma hepatocelular. Hallaron que la técnica anestésica era un predictor significativo de supervivencia libre de recurrencia, aunque no hubo diferencias en cuanto a la mortalidad [117]. Tampoco se observaron diferencias significativas en ningún sentido en cáncer renal y cervical. 
Tabla III. Muestra de investigaciones de analgesia regional y su relación con la recurrencia oncológica

\begin{tabular}{|l|l|l|l|l|l|}
\hline Autor & $\begin{array}{l}\text { Tipo } \\
\text { tumoral }\end{array}$ & $\begin{array}{l}\text { Tipo de } \\
\text { anestesia } \\
\text { regional }\end{array}$ & Año & Resultados & $\begin{array}{l}\text { Tipo de } \\
\text { estudio }\end{array}$ \\
\hline $\begin{array}{l}\text { Schlagenh } \\
\text { auff [110] }\end{array}$ & Melanoma & Local & 2000 & Favorable & Retrospectivo \\
\hline $\begin{array}{l}\text { Exadaktylos } \\
\text { [90] }\end{array}$ & Mama & Paravertebral & 2006 & Favorable & Retrospectivo \\
\hline Biki [111] & Próstata & Epidural & 2008 & Favorable & Retrospectivo \\
\hline $\begin{array}{l}\text { Christopher- } \\
\text { son [118] }\end{array}$ & Colon & Epidural & 2008 & Favorable & Retrospectivo \\
\hline Ismail [119] & Cérvix & Epidural & 2010 & Favorable & Retrospectivo \\
\hline Myles [120] & Abdominal & Epidural & 2011 & No concluyente & Prospectivo \\
\hline $\begin{array}{l}\text { De Oliveira } \\
\text { [113] }\end{array}$ & Ovario & Epidural & 2011 & Favorable & Retrospectivo \\
\hline
\end{tabular}

En 2.012 un amplio estudio de cohortes que incluía más de $\mathbf{4 2 . 0 0 0}$ pacientes sometidos a colectomía por cáncer encontró que la supervivencia a 5 años fue mayor (61\%) en el grupo que recibió analgesia epidural (un 22\% del total de los casos revisados) frente al grupo que recibió un, pobremente definido, manejo tradicional del dolor (55\%). No obstante, no hallaron pruebas de una menor recurrencia tumoral por la utilización del bloqueo epidural [121].

Sin embargo, hasta la fecha, el único ensayo randomizado prospectivo en humanos ha sido realizado por Myles y colaboradores. La muestra incluyó 446 pacientes, todos ellos sometidos a cirugía abdominal mayor para resección tumoral maligna, a quienes se les realizó un seguimiento de 9 a 15 años. Las cirugías que se realizaron fueron esofaguectomía, gastrectomía, hepatectomía, pancreatectomía, colectomía, nefrectomía, cistectomía, histerectomía radical y prostatectomía abierta. No fueron incluidos aquellos pacientes que presentaban metástasis en el momento de la cirugía. De los 2 grupos en que se dividió, uno recibió analgesia controlada por el paciente basada en opioides, mientras el otro fue analgesiado mediante bloqueo epidural a nivel torácico. 
Los resultados que obtuvieron no pudieron apoyar la hipótesis que sugiere que el bloqueo regional epidural podría reducir el riesgo de recurrencia del cáncer, ya que los datos acerca de supervivencia libre de enfermedad y mortalidad fueron casi idénticos en ambos grupos. Aunque se observaron otros factores asociados a la menor supervivencia libre de enfermedad tras la cirugía, a saber, edad avanzada, sexo femenino y transfusión intraoperatoria de sangre, resultados consistentes con la literatura previa.

De esta manera, los autores sugirieron que los datos de estudios in vitro, en animales, y observacionales en humanos acerca del bloqueo regional y recurrencia del cáncer deben ser extrapolados a los pacientes con precaución. Así, consideran que aunque existen razones a corto plazo para emplear la analgesia epidural, la reducción del riesgo a largo plazo de la recurrencia tumoral podría no estar entre ellas. Concluyen que la decisión de emplear bloqueo epidural en combinación con anestesia general deberá basarse en otras consideraciones, como por ejemplo, evitar los efectos de los analgésicos opioides [120].

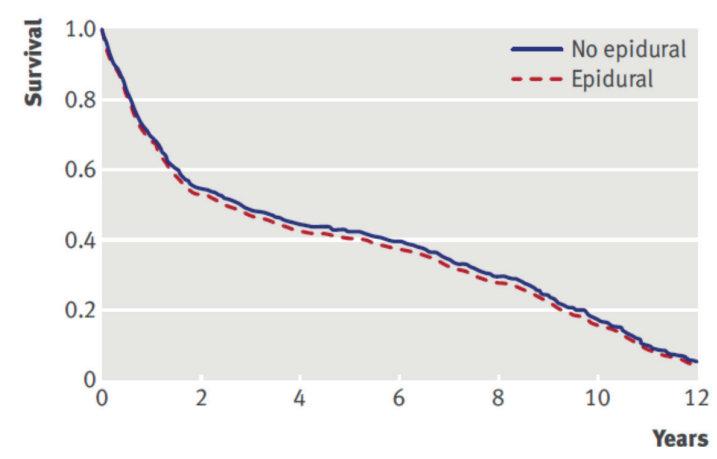

Figura 8. Curva de supervivencia en grupo epidural y no epidural (Myles et al [120])

\subsection{Posibles mecanismos}

La reducción de la necesidad de anestésicos generales al emplear analgesia regional es sustancial, de hasta un factor de 5, lo que puede consecuentemente favorecer la inmunidad antitumoral al promover la dominancia Th1, preservando el número de células NK y manteniendo las respuestas linfocitarias a diversos mitógenos. Presumiblemente, al descender los anestésicos volátiles también se vería reducida su acción sobre los genes que favorecen la promoción tumoral.

Los beneficios inmunes de combinar la analgesia regional con la anestesia general no obstante, permanecen sin aclarar completamente, en parte porque los 
efectos antiinmunes de los anestésicos volátiles pueden ser clínicamente importantes incluso a bajas CAM. Por ejemplo, la actividad fagocítica de los neutrófilos, el número de linfocitos, el contaje de células NK y su actividad descienden de forma similar en pacientes sometidos a cirugía tanto bajo anestesia sólo con agentes volátiles como combinada con analgesia epidural.

Para complicarlo aún más, los efectos de los opioides sobre el sistema inmune pueden haberse confundido con las acciones puras de la analgesia regional. Así, mientras el uso exclusivamente en el postoperatorio de analgesia regional es antiinflamatorio y ayuda a mantener la función inmune, el beneficio es aún mayor cuando la analgesia regional se emplea durante el periodo intraoperatorio para continuarse en el postoperatorio, habiéndose encontrado con tal abordaje una mayor supervivencia libre de enfermedad tras cirugía oncológica de ovario frente al abordaje en el postoperatorio, eso sí, de forma retrospectiva. Esto puede ser debido al hecho de que se emplean dosis más altas de opioides cuando no se emplea una analgesia combinada. Consecuentemente, los opioides aportados intraoperatoriamente se mantienen en el organismo postoperatoriamente y presumiblemente continúan alterando las funciones inmunes incluyendo la actividad de NK.

Las diferencias entre los estudios clínicos pueden ser explicadas por el hecho de que las acciones de los opioides sobre el sistema inmune varían, con algunos causando mayor inmunosupresión, como la morfina, remifentanilo, fentanilo, que otros, como la buprenorfina, hidromorfona, oxicodona y tramadol. Así, los efectos inmunes de la analgesia regional y la disminución del consumo de opioides presumiblemente dependen, al menos en cierta medida, del tipo de opioide utilizado para el control de dolor.

Adicionalmente, se ha observado que la analgesia regional preserva la función inmune incluso sin la reducción en el empleo de opioides y anestésicos generales. Este hecho sugiere que ejerce su efecto al bloquear la liberación sistémica de las catecolaminas circulantes tanto intra como postoperatoriamente, ya que los efectos inmunes de la anestesia regional en el tejido local tras la lesión tisular son mínimos.

Los potenciales beneficios de la analgesia regional sobre la respuesta inflamatoria y el sistema inmune pueden variar de acuerdo con la técnica de anestesia regional (epidural versus bloqueo mayor, por ejemplo), la altura del bloqueo en técnicas neuroaxiales (lumbar versus torácico, por ejemplo), y según el anestésico local empleado (bupivacaína, ropivacaína, lidocaína). Aún es más, la adición de opioides a los anestésicos locales puede aportar un bloqueo mayor a la rama sensorial cuando se administra neuraxialmente, provocando consecuentemente una menor activación del sistema nervioso autónomo por dolor. De forma interesante, los opioides admi- 
nistrados centralmente pueden activar la liberación de IL-6 a través de la activación de la corteza adrenal y, así, posiblemente bloquear las defensas tumorales en mayor medida de lo esperado basado en las menores dosis de opioides que se administran neuraxialmente [122-124].

Posteriormente, y en la misma línea de trabajo que Bar-Yosef, Wada et al también demostraron que la combinación de anestesia espinal con anestesia general atenuaba la formación de metástasis en tamaño y número, en este caso hepáticas, en ratas inoculadas con células EL4 de linfoma de células T y sometidas al estrés quirúrgico de una laparotomía, con respecto al grupo que recibió morfina [125].

Adicionalmente, examinaron la relación de citoquinas linfocitarias Th1/Th2 en muestras del tejido tumoral observando que se producía una preservación de la misma, lo que se considera asociado a un favorable pronóstico oncológico. Así, un estado Th2 dominante posee un papel negativo en la inmunidad oncológica. De esta manera, el empleo de anestesia general o combinada mantuvo o incluso aumentó la relación de citoquinas IFN- y/IL-1 o relación linfocitaria Th1/Th2. Pero se veía reducida de forma significativa en los grupos sometidos a cirugía, siendo significativamente mayor la disminución en las ratas anestesiadas sólo con sevoflurano frente a aquellas en las que se empleó anestesia combinada.

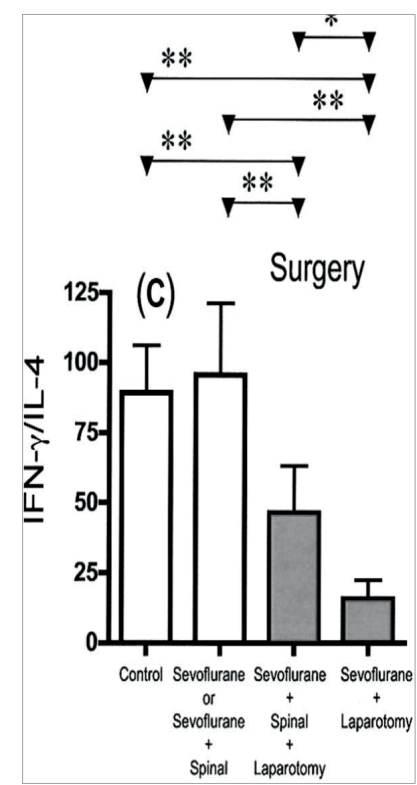

Figura 9. Diferencias en la relación de citoquinas antitumorales y protumorales (Wada et al [125]) 
Le Cras estudió este mismo equilibrio linfocitario en pacientes sometidos a cirugía prostática no oncológica, observando similares resultados, de manera que el bloqueo espinal preservó la relación Th1/Th2 hacia un estado Th1 dominante en comparación con la anestesia general [126].

Y otro trabajo en humanos sometidos a hepatectomía tumoral bajo anestesia con sevoflurano combinada con epidural mostró un mantenimiento de dicha dominancia Th1, frente a los que recibieron anestesia general sin epidural y con morfina como analgésico. Los autores concluyeron que la anestesia epidural asociada a la general podría ser superior a la anestesia general en cuanto a un desenlace clínico favorable [127].

En esta línea, otros estudios muestran ciertos factores estresantes como causantes de supresión selectiva de la respuesta Th1, como la elevación de los niveles de glucocorticoides y noradrenalina, incluyendo la administración exógena de dichos esteroides. Estos resultados sugieren indirectamente que la anestesia espinal atenúa la elevación postoperatoria de hormonas de estrés.

El bloqueo paravertebral torácico en cirugía oncológica de mama podría representar una mejora en términos de disminución de la recurrencia tumoral y de la aparición de metástasis. En un estudio de seguimiento de 2,5 a 4 años se vio asociado a una reducción de aproximadamente una cuarta parte del riesgo de recurrencia o de desarrollo de metástasis.

El bloqueo paravertebral torácico descendió la respuesta al estrés quirúrgico además del consumo de opioides, permitiendo amortiguar los efectos deletéreos de ambos sobre las funciones inmunes celulares y humorales [51], de forma similar a la epidural en estudios de cáncer prostático [128] y de recto, aunque no de colon [129].

Además, se ha valorado la capacidad del bloqueo paravertebral torácico para disminuir los niveles sanguíneos de la molécula proangiogénica VEGF en pacientes oncológicas sometidas a cirugía de resección. Looney et al hallaron una reducción de los niveles de VEGF en aquellas pacientes que recibieron analgesia paravertebral junto a anestesia general con propofol frente a aquellas que recibieron sevoflurano y morfina. Un estudio previo no tuvo éxito en este sentido ni tampoco en cuanto a la disminución de los niveles de prostaglandina E2, implicada también en la progresión tumoral, en las pacientes que recibieron analgesia paravertebral frente a aquellas a las que se les administró morfina intravenosa [51]. Sin embargo, a diferencia del primer estudio, ambos grupos de pacientes comparados recibieron sevoflurano como anestésico general [49]. 
En 2.010 Deegan et al, en su estudio prospectivo randomizado, encontraron que en 32 pacientes ASA I-III, de edades entre 18 y 85 años, sometidas a cirugía de cáncer de mama para mastectomía y extirpación de ganglio centinela o bien tumorectomía amplia, hubo una disminución significativa de la IL-1 $\beta$, de las metaloproteinasas de matriz 3 (MMP-3) y MMP-9 (de carácter protumoral) y un significativo incremento de la IL-10 (alrededor del 10\%). Sólo hubo diferencias significativas en 2 de las 11 citoquinas observadas y en 2 de las 3 MMP estudiadas. Fueron sometidas de forma aleatoria a anestesia balanceada con propofol y analgesia mediante bloqueo paravertebral a nivel T2-T3 o bien a anestesia general y analgesia postoperatoria con morfina.

El aumento de los niveles de IL-1 $\beta$ en el cáncer de mama está considerado como marcador de mal pronóstico. Los efectos de la IL-10 sobre el crecimiento tumoral son complejos y no completamente conocidos. Inhibe la producción de citoquinas las proinflamatorias IL-1, IL-6 e interleuquina-8 (IL-8), el factor de necrosis tumoral TNFa y las MMP, mostrando además actividad antitumoral y antimetastásica al potenciar la respuesta de las células Natural Killer provocando lisis tumoral. Sin embargo, también se ha asociado a un peor pronóstico. El incremento en IL-10 fue modesto entre ambos grupos.

Los resultados de este estudio parecen consistentes con la hipótesis que propone que la anestesia combinada propofol/bloqueo paravertebral preserva la defensa inmune frente a la progresión tumoral con respecto al empleo de sevoflurano con morfina. Por el contrario, la ausencia de cambios significativos en la mayoría de las moléculas valoradas parece contradecir dicha hipótesis y abre la posibilidad de que los cambios observados fueran simplemente aleatorios. Pero de acuerdo con la hipótesis existen los estudios in vivo comentados, que muestran que una analgesia postoperatoria óptima incluida la anestesia regional reduce las metástasis en animales inoculados con células de adenocarcinoma mamario.

Los autores concluyeron que, aunque observaron diferencias significativas en citoquinas de importancia oncológica, desconocían si la escasa cuantía de estas diferencias puede ser suficiente para cambiar el comportamiento celular tanto in vitro como en modelos experimentales [48].

El mismo autor investigó el potencial efecto de la técnica anestésica perioperatoria sobre el comportamiento metastásico de las células de cáncer mamario. En su estudio prospectivo y randomizado evaluaron el efecto del suero obtenido de pacientes sometidas a cirugía oncológica de mama sobre la funciones de las células tumorales mamarias MDA-MB-231 in vitro. Las pacientes recibieron bien anestesia combinada regional mediante bloqueo nervioso paravertebral homolateral con propo- 
fol como anestésico general o bien anestesia general con sevoflurano y morfina. Los resultados mostraron que hubo significativemente menor proliferación celular cuando dichas células se pusieron en contacto con el suero de las pacientes operadas bajo anestesia combinada con anestesia regional y propofol frente al grupo que recibió el suero de pacientes bajo anestesia con sevoflurano y morfina. Desafortunadamente, no pudieron encontrar diferencias significativas en cuanto a la migración de células tumorales. Una posible explicación para estos resultados es que el perfil molecular del suero de estas pacientes podría encontrarse alterado como resultado de la técnica anestésica. La habilidad de atenuar la proliferación o migración de esta línea celular altamente agresiva modificando de forma fácil y segura la forma de administración de la anestesia para la cirugía del tumor primario podría tener importantes implicaciones clínicas. Es importante que, aunque la muestra de pacientes fue pequeña, fue suficiente para encontrar diferencias significativas en los parámetros estudiados [131].

En estos estudios no sólo se pretende poner de manifiesto la diferencia con el empleo de anestesia regional versus morfina, sino el empleo de un paquete anestésico (propofol/paravertebral) diferente frente a otro (sevoflurano/morfina).

\subsection{Perspectivas de futuro}

Con todo lo anteriormente expuesto, se evidencia la necesidad de más ensayos, de mayor tamaño muestral, prospectivos y randomizados que puedan aportar luz sobre el significado de los resultados de los estudios previos. En este sentido existen varios estudios prospectivos en curso.

Sessler et al están llevando a cabo un ensayo multicéntrico randomizado y prospectivo sobre el uso de analgesia regional (bloqueo paravertebral torácico o epidural torácica) frente al uso de morfina para la cirugía de cáncer de mama con el objetivo de valorar si reduce la aparición de metástasis, cuyos resultados tardarán varios años en aparecer (NCT00418457). Su hipótesis primaria consiste en que la recurrencia local y metastásica del cáncer tras cirugía primaria del mismo se ve reducida cuando los pacientes reciben analgesia regional combinada con anestesia ligera o sedación frente al empleo de anestesia con sevoflurano y analgesia postoperatoria opioide. Como hipótesis secundaria proponen una reducción de la mortalidad global en el primer grupo de pacientes. Precisan reclutar cerca de 1.100 pacientes durante 5 años. Los criterios de inclusión son pacientes con cáncer de mama sin extensión conocida más allá de la mama o de los ganglios linfáticos que sean sometidas a mastectomía uni o bilateral con o sin implante protésico o bien a mastectomía parcial con disección ganglionar axilar [20,132,133]. 
En 2.007 comenzaron estudios similares para comprobar la hipótesis acerca de la reducción de recurrencia de cáncer, en este caso endometrial (NCT00531349) [134], de colon (NCT00684229) [135] y de pulmón (NCT01179308) [136] en pacientes sometidos a analgesia regional combinada con sedación o anestesia ligera frente a pacientes sometidos a anestesia general con analgesia opioide. A su vez, se está realizando un ensayo clínico sobre analgesia epidural versus analgesia controlada por el paciente y su efecto la mortalidad a largo plazo tras cirugía de cáncer colorrectal (NCT01318161) [137]. Otros se encuentran comparando la recurrencia postquirúrgica del melanoma y cáncer de páncreas en pacientes sometidos a anestesia regional frente a analgesia opioide [138,139], y valorando la cantidad de células circulantes postquirúrgicamente [140]. Desafortunadamente, el ensayo NCT00531349 que evaluaba la anestesia epidural y desenlace del cáncer endometrial fue suspendido debido a la falta de reclutamiento de pacientes.

En definitiva, varios ensayos prospectivos randomizados de analgesia regional y recurrencia del cáncer se han iniciado en los últimos años. Sin embargo, debido al tiempo necesario para enrrolar a los pacientes y a la necesidad de observación prolongada para conocer la aparición o no de recurrencia, los resultados probablemente no estén disponibles hasta dentro de varios años.

\subsection{Anestésicos locales y cáncer}

Algunos autores preconizan que la analgesia locorregional podría tener su efecto beneficioso no sólo por una acción indirecta mediante el bloqueo de la inflamación y de la respuesta a la lesión tisular, sino también por una acción directa, por parte de los anestésicos locales, sobre las células tumorales y sus capacidades de crecimiento, extravasación y metastatización.
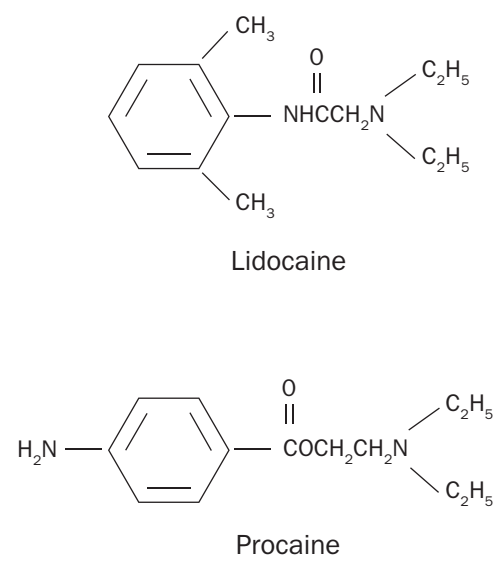

Figura 10. Estructura molecular de los anestésicos locales prototipo 
Los anestésicos locales se encuentran constituidos por tres partes: un radical lipofílico o aromático, uno hidrofílico (amina) y una zona de unión entre ambos. Según contenga, la unión, un aminoéster o una aminoamida, los anestésicos locales se clasifican, respectivamente, en tipo éster o tipo amida. La procaína es el prototipo de anestésico local de tipo aminoéster, y la lidocaína es el prototipo de aminoamida.

Su principal acción es provocar un bloqueo motor y sensitivo mediante el bloqueo reversible de los canales de sodio voltaje-dependientes en los axones neuronales, anulando el desarrollo del potencial de acción, necesario para la transmisión del impulso nervioso. Para ello, deben ser depositados en las proximidades de los nervios.

La vascularización del lugar de la inyección está en estrecha relación con la absorción sistémica de los anestésicos locales. La absorción sistémica de mayor a menor grado se puntualiza a continuación: intravenoso, traqueal, intercostal, paracervical, epidural, plexo braquial, ciático, subcutáneo.

Desde hace dos décadas continúan apareciendo nuevos datos acerca de los beneficios potenciales de estos fármacos. Así, otros efectos documentados, llamados pleiotrópicos, de estos fármacos son neuroprotección, tratamiento del íleo postoperatorio, de cefaleas, de proctalgia, del hipo, efectos sobre procesos inflamatorios, antinociceptivos, antitrombóticos. El futuro de los anestésicos locales parece prometedor.

En cuanto al efecto de los anestésicos locales sobre las células tumorales, se ha encontrado que altas dosis de los mismos son citotóxicas sobre las células tumorales, ya que las sensibilizan frente al calor y frente a la acción de los agentes quimioterápicos, potenciando sus efectos beneficiosos. La procaína permite incrementar el índice terapéutico del cisplatino en tumores malignos de testículo, ovario y vejiga, además de disminuir su neurotoxicidad y hemotoxicidad [141-143].

Más aún, estos fármacos han mostrado proteger contra la invasión tumoral en las concentraciones clínicas encontradas tras infiltración local. Son capaces de suprimir la proliferación in vitro de una variedad de células tumorales, al modular la biología tumoral.

En los tumores malignos se sabe que la metilación silencia los genes supresores tumorales llevando a la progresión tumoral. Se ha observado que la procaína, prototipo de los anestésicos locales tipo éster, desmetila el ácido desoxirribonucleico (ADN) inhibiendo de esta manera el crecimiento tumoral de células de cáncer de 
mama, melanoma y leucemia. En la misma línea, la lidocaína, prototipo del tipo amida, desmetila el ADN de las células de cáncer de mama BT-20 ERnegativas (Estrogen Receptor) y MCF-7 ERpositivas, siendo incluso más potente en esta tarea que la procaína [144]. A su vez, la lidocaína, al igual que la ropivacaína inhibe la actividad de enzimas relacionadas con la inflamación como la Src tirosina-quinasa, modulándola. Efecto, éste, no conseguido por la cloroprocaína, anestésico local de tipo éster. Además, son capaces de inhibir la migración de células tumorales H838. La ropivacaína fue capaz de proteger frente a la inflamación incluso antes del estímulo inflamatorio. La lidocaína y ropivacaína también se han mostrado implicadas en una reducción de la migración y metástasis de células tumorales al inhibir la fosforilación de ICAM-1 [145].

Son varios los estudios que muestran un efecto protector selectivo de los anestésicos locales tipo amida frente a los de tipo éster [146]. Se sabe que los anestésicos locales de tipo amida, al contrario que los de tipo éster, pueden mostrar efectos inhibitorios del proceso inflamatorio, como por ejemplo la ropivacaína en la inflamación pulmonar [147] o la lidocaína en cirugía colorrectal [148].

\subsection{Bloqueo paravertebral}

El bloqueo paravertebral es una técnica de anestesia regional empleada cuando una analgesia unilateral de la región cervical, torácica o lumbar es requerida. Consistente en la inyección de una solución de anestésico local a lo largo de la columna vertebral, cerca de la salida de los nervios espinales, provocando un bloqueo sensorial, motor y simpático unilateral, para un volumen de anestésico dado, el bloqueo simpático que causa es de mayor extensión que el somático.

Aporta una analgesia de alta calidad que puede ser usada incluso como técnica anestésica única, sin necesidad de emplear opioides ni agentes hipnóticos, en pacientes que van a ser sometidos a muy diversos tipos de cirugía, y también en aquellos que han sufrido traumatismos o padecen dolor crónico.

\subsection{Historia}

La primera descripción del bloqueo fue realizada por Sellheim en 1905 proponiéndola como posible alternativa a bloqueos nerviosos centrales para obstetricia, en particular para las cesáreas. Arthur Läwen, un residente de cirugía estudió especialmente esta técnica. A través de la inyección de pequeñas cantidades de procaína en la salida de cada nervio espinal, en pacientes aquejados de dolor abdominal, pudo 
mapear la inervación segmentaria. Aunque inicialmente se empleó para el alivio del dolor quirúrgico, sus indicaciones aumentaron empleándose para el dolor anginoso, causalgia o distrofia simpática, incluso se usó para tratar la taquicardia supraventricular, asma bronquial, alivio de cólicos renal y biliar. En la primera mitad del siglo 20 se empleó ampliamente incluso de forma bilateral. Aunque cayó en desuso, la técnica fue revitalizada por Eason y Wyatt en 1979, describiendo una técnica que además empleaba un catéter. Saabbanatha, Richardson y Lonnqvist han contribuido recientemente de forma sustancial al entendimiento de la técnica [149-151].

El bloqueo puede realizarse a nivel cervical, torácico o lumbar, siendo el de mayor interés para el presente trabajo el bloqueo paravertebral a nivel torácico, cuya técnica se describirá más adelante.

\subsection{Anatomía}

El espacio paravertebral es, anatómicamente, un espacio virtual, creado temporalmente por la inyección de un fluido, que tiene forma de cuña formada por el ligamento costotransverso (que va del borde inferior de la apófisis tranversa vertebral superior al borde superior de la costilla inferior) en la cara posterior, medialmente por la cara posterolateral del cuerpo vertebral, los discos intervertebrales y los agujeros intervertebrales, y por la pleura parietal y (fascia endotorácica) en la vertiente anterolateral. El techo y suelo del espacio están formados por las cabezas costales superior e inferior.

El espacio se encuentra ocupado por la raíz espinal, (que se ramifica dando 3 ramas: una rama posterior que inerva piel y músculos de la región paravertebral, el ramo comunicante que forma parte de la cadena simpática, y el inicio del nervio intercostal) su ramo ventral se dirige a la cadena simpática y los ramos dorsales postganglionares grises y comunicantes dorsales permanecen en este espacio, junto a tejido graso. La estructura nerviosa en este nivel está desprovista de vaina fascial y es más o menos filamentosa y, por este motivo, el anestésico local penetra fácilmente en el nervio intercostal y sus adyacentes. El espacio paravertebral es continuo, con el espacio intercostal situado de forma lateral, medialmente el espacio epidural y el espacio paravertebral contralateral a través de la fascia prevertebral $[151,152]$. 


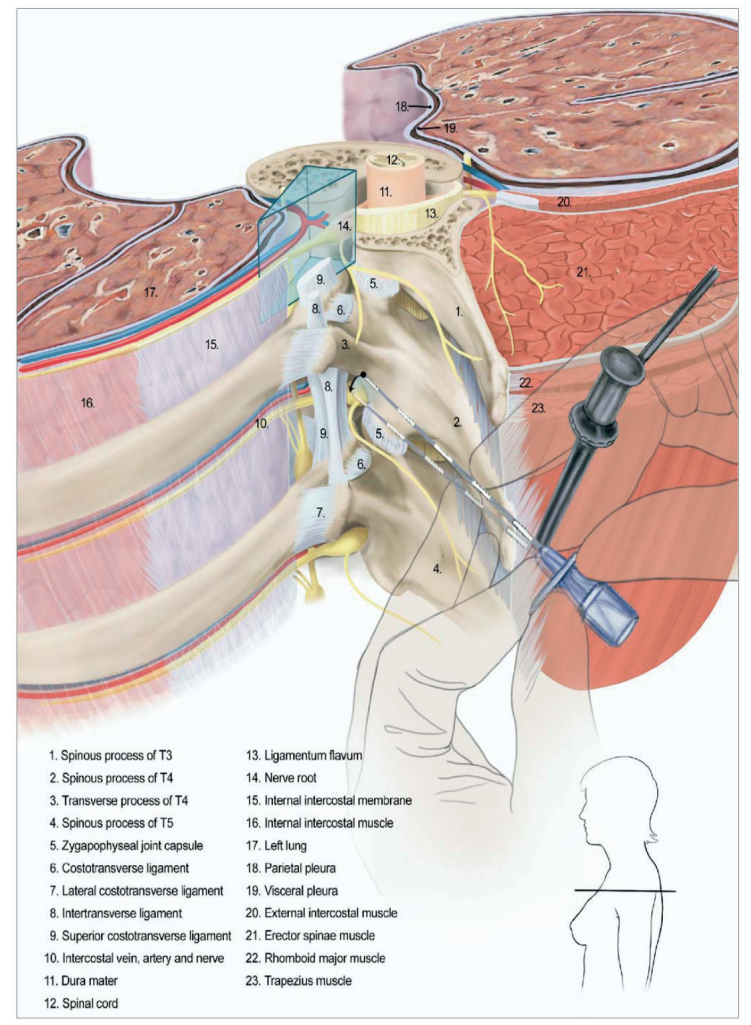

Figura 11. Anatomía y técnica de bloqueo paravertebral a nivel torácico

\subsection{Técnica}

A efectos prácticos, para el presente trabajo serán descritos únicamente los pasos de la técnica de bloqueo nervioso paravertebral a nivel torácico (BPVT). La técnica clásica se basa en la búsqueda de pérdida de resistencia para la localización del espacio paravertebral donde se inyectará el anestésico local. La localización del espacio paravertebral puede tener mayor dificultad en pacientes obesos o musculados y en aquellos con toracotomía previa o cicatriz del espacio.

Con el paciente sentado o bien en decúbito lateral, con el lado a bloquear encima o bien en decúbito prono, palparemos la apófisis espinosa en la línea media. La aguja apropiada debe avanzarse horizontalmente perpendicular a la piel en sentido posteroanterior en el dermatoma elegido, entre 4 y $6 \mathrm{~cm}$ de profundidad, dependiendo de la edad y complexión del paciente, hasta hacer contacto con la apófisis transversa vertebral, a una distancia lateral de $2,5 \mathrm{~cm}$ a la apófisis espinosa de la vértebra elegida (superior). Este punto de referencia es muy importante para prevenir la punción pleural. A continuación, la aguja es redireccionada unos $15-20^{\circ}$ bien craneal o caudalmente a la apófisis transversa y avanzada cabalgando la apófisis transversa hasta 
sentir una pérdida de resistencia al aire o al suero fisiológico, o bien un sutil click al atravesar el ligamento costotransverso. La percepción de la pérdida de resistencia puede ser difícil, por eso algunos autores hablan de una incidencia, aunque baja, de neumotórax tras avanzar 1-1,5 cm la aguja por el borde de la apófisis transversa. La inserción del catéter, que puede resultar algo dificultosa, será de un máximo de $4 \mathrm{~cm}$. Una inserción demasiado suave del catéter podría indicar localización interpleural, epidural o intratecal del mismo.

Antes de la inyección de fármacos, debe aspirarse siempre cuidadosamente a través de la jeringa con el fin de evitar la administración intravascular, intrapleural y/o bien espinal (intradural o epidural).

La difusión del anestésico local tanto caudal como cefálicamente permite que su efecto analgésico se distribuya a lo largo de los 4-5 dermatomas adyacentes e ipsilaterales al lugar de la punción, permitiendo obtener una amplia zona analgesiada con una sola punción. La extensión depende del volumen del anestésico local y del nivel de la punción [153].

\subsection{Variantes técnicas}

La inyección puede realizarse a través de punción única en un solo espacio paravertebral o bien a través de punciones múltiples sobre varios espacios adyacentes. El bloqueo con inyecciones en múltiples niveles permite descender la incidencia de segmentos sin bloquear y evitar la inyección masiva intravascular o intratecal al fraccionar la dosis total de anestésico local. Algunos autores consideran esta técnica preferible si se quiere un bloqueo muy extenso. No obstante, la inyección única permite disminuir el discomfort del paciente, el tiempo de realización del bloqueo y las complicaciones asociadas a las punciones, además de permitir también el bloqueo de múltiples niveles metaméricos.

La aguja puede, a su vez, variar, entre una aguja espinal tipo Whitacre $22 \mathrm{G}$ o bien tipo Tuohy 18G, esta última en caso de buscar la inserción de un catéter con el objetivo de añadir dosis suplementarias de anestésico de forma tanto continua como intermitente.

Ha sido empleada habitualmente como técnica unilateral, homolateral al lado de la lesión, pero también se ha informado de su uso de forma bilateral, con buenos resultados en cirugía cardiaca, mamaria y torácica, aunque en estos casos se presenta mayor riesgo de sobrepasar la dosis tóxica del anestésico local [154]. 
El empleo de ultrasonidos puede ayudar a calcular la profundidad de inserción de la aguja, al visualizar las distintas referencias anatómicas, aunque aún está por evaluar su eficacia en la reducción de la aparición de complicaciones [155]. A su vez se está valorando la utilidad de la nueva ecografía en 3 dimensiones [156].

Ciertos autores defienden la utilización de neuroestimulador con el fin de localizar los nervios a bloquear, sobre todo en pacientes que presentan ciertas dificultades anatómicas (obesidad, espondilitis anquilopoyética), empleando una intensidad de $\mathbf{5}$ mA. En estos casos, la respuesta obtenida será segmentaria, pero no siempre objetivable [154].

\subsection{Ventajas}

La técnica puede ser realizada tanto previa como posteriormente a la cirugía. Una de las ventajas de realizarse antes de la misma es su utilidad como analgesia intraoperatoria, pudiendo ser incluso empleada como técnica anestésica única o con necesidad sólo de sedación, evitando, por tanto, la anestesia general, lo que puede ser de gran ventaja en pacientes de alto riesgo, por ejemplo pacientes ASA 3-4 [157].

La respuesta al estrés y la función ventilatoria postoperatoria fueron mejores en comparación con el empleo de analgesia intravenosa [158], y se ha mostrado efectiva en la reducción de la incidencia de dolor crónico de la herida quirúrgica [159]. Así, el bloqueo paravertebral torácico es una técnica relativamente sencilla, revelándonse como una alternativa válida a la epidural.

\subsection{Complicaciones}

La principal complicación es el fallo de la técnica, que aparece entre un 7 y 10 $\%$ de las ocasiones, siendo de cuantía similar a otras técnicas regionales. La toxicidad asociada a los anestésicos locales, como convulsiones, aparece por su paso intravascular inadvertido o por exceso de dosis. La inyección intravascular se puede evitar con la aspiración intermitente y el uso de adrenalina junto al anestésico local. La incidencia es de sólo el 3,8\%, a pesar de la amplia vascularización de la zona. El empleo de un bloqueo bilateral multinivel duplica el riesgo de punción vascular inadvertida, y multiplica por 8 el riesgo de punción pleural y neumotórax. Parece que el empleo bilateral con punciones en un solo nivel es más seguro. La reabsorción del anestésico es similar a la que se produce en el bloqueo epidural o del plexo braquial, e inferior a la del bloqueo interpleural e intercostal. 
La punción pleural accidental es una complicación poco común, entre el 0,5 y el $1 \%$ de los casos. Está directamente relacionada con el número de punciones realizadas [160]. Debe sospecharse ante la aparición de tos durante la realización de la punción. Otros síntomas son dolor de hombro o torácico, excesiva facilidad a la inyección del anestésico o a la inserción del catéter. Estas situaciones, requieren vigilancia de su evolución mediante radiografías de tórax por posible desarrollo de neumotórax. Es esencial localizar la apófisis transversa antes de avanzar la aguja para evitar esta lesión pleuropulmonar. Si aparece neumotórax suele ser de escasa entidad, y su manejo, habitualmente, conservador.

La difusión epidural a través de los manguitos que se extienden desde la línea media hasta el espacio paravertebral, tiene una incidencia es del 1,1\%, mientras la extensión bilateral a nivel torácico es difícil. Otros autores no encontraron evidencia clínica ni radiológica de extensión contralateral en 61 pacientes sometidos a bloqueo multinivel mediante estimulador. La inyección intrarraquídea con punción intratecal con anestesia espinal total y la cefalea postpunción son raras, y aparecen cuando la aproximación se hace muy medial, debido a la proximidad de la aguja a la duramadre y agujero intervertebral.

En solo un $5 \%$ de las ocasiones, se produce hipotensión por bloqueo simpático unilateral, con similar tasa en caso de bloqueo bilateral, siendo más habitual en pacientes hipovolémicos ya que el bloqueo paravertebral desenmascara dicha situación. Serán pocas las ocasiones que requieran tratamiento con vasoconstrictores. Es menor la repercusión hemodinámica que con la técnica epidural, dada también su menor difusión. Algunos pacientes desarrollan hipotensión debida a una reacción vasovagal.

La presencia de síndrome de Claude-Bernard-Horner (miosis, ptosis palpebral, y falta de sudoración unilateral) indica que se alcanza un nivel de bloqueo simpático cervical C6-T1. En estos casos, se debe vigilar la presencia de bloqueo frénico y/o recurrente laríngeo. Se ha descrito también la aparición de este síndrome de forma bilateral por difusión del anestésico local o cruce de fibras nerviosas simpáticas.

Otras complicaciones potenciales publicadas son hemorragia pulmonar, dolor torácico segmentario por traumatismo del nervio intercostal y dolor en el lugar de la inyección. Hasta la fecha no hay casos descritos de fallecimiento a causa de este bloqueo [149,153,161]. En 2.012 los autores Luyet et al publicaron una tasa elevada de malposición del catéter en los pacientes, incluso cuando la técnica se realizó con ultrasonidos [162]. 


\subsection{Indicaciones}

Entre las principales indicaciones de la realización del bloqueo paravertebral se encuentran las siguientes:

Dolor agudo y quirúrgico:

- Cirugía de mama uni o bilateral.

- Analgesia intra y postoperatoria en intervenciones quirúrgicas o percutáneas de vesícula biliar.

- Analgesia intra y postoperatoria en intervenciones nefro-ureterales.

- Analgesia intra y postoperatoria en intervenciones quirúrgicas o percutáneas hepatobiliares.

- Analgesia intra y postoperatoria en intervenciones de cirugía torácica.

- Analgesia intra y postoperatoria en intervenciones de cirugía cardiaca.

- Herniorrafia.

- Apendicectomía.

- Fracturas costales.

- Dolor cápsula hepática postraumático.

- Dolor pleural.

- Hiperhidrosis.

- Cólicos nefríticos.

- Pancreatitis aguda.

Dolor crónico:

- Neuralgia postherpética.

- Neuralgias benignas y malignas. 
- Pancreatitis crónica.

- Distrofia simpática refleja del tórax.

\subsection{Contraindicaciones}

La anestesia paravertebral está contraindicada fundamentalmente en la infección localizada, infección intrapulmonar o empiema, al igual que en las grandes deformidades torácicas, con el fin de evitar la posible entrada de anestésico en la zona espinal. Para algunos autores incluso está contraindicada en cirugía ambulatoria, dadas sus potencialmente graves complicaciones [163].

\subsection{Bloqueo paravertebral y cirugía de mama}

\section{A. Inervación mamaria}

Las fibras sensoriales llevan, desde la mama, información táctil y térmica hacia el Sistema Nervioso Central. La sensibilidad cutánea de la mama, aunque varía entre mujeres, es más consistente por encima del pezón que por debajo. La areola y pezón son las zonas más sensibles dada la alta densidad de terminaciones nerviosas en los mismos. Las mamas de menor tamaño son más sensibles que las de mayor tamaño.

Jaspars et al estudiaron exhaustivamente la inervación de la mama. La inervación cutánea medial de la mama procede principalmente de las ramas cutáneas anteriores de los nervios intercostales torácicos primero (T1) a sexto (T6). Mientras, la sensibilidad de la parte lateral es recogida por la rama cutánea lateral de la metámera T2 a la T7. La areola y pezón son, a su vez, inervados por el intercostal T4 con la contribución de las ramas anteriores y laterales, y aportaciones de T3 y T5.

Ramas sensitivas procedentes del plexo cervical (raíces C3 y C4) inervan el espacio infraclavicular pueden contribuir también a la inervación mamaria. El nervio pectoral mayor recoge igualmente sensibilidad de la región infraclavicular. La extensión de la que cada nervio intercostal recoge sensibilidad de la mama es variable incluso en una misma paciente. En la cirugía de la mama son prioritarias las ramas cutáneas anteriores de las 5 primeras metámeras [164]. 


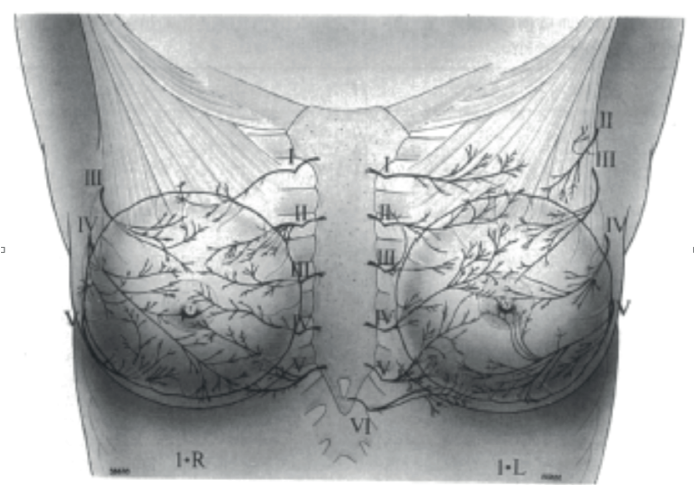

Figura 12. Inervación mamaria superficial

\section{B. Bloqueo paravertebral y cirugía de mama}

El bloqueo paravertebral a nivel torácico (BPVT) ha demostrado ser una técnica sencilla y muy segura para cirugía mamaria tanto oncológica como de otro tipo, empleada como adyuvante considerándose incluso una alternativa válida a la anestesia general. Richardson propuso el bloqueo paravertebral como una excelente indicación de "estándar de oro" en la cirugía mamaria unilateral, por su alto índice de éxitos, pocas implicaciones, e inapreciables repercusiones hemodinámicas o respiratorias [161].

El empleo de anestesia paravertebral en este tipo de cirugía presenta múltiples ventajas. Aporta una calidad analgésica superior y menos efectos secundarios en relación al empleo de opioides, al facilitar una disminución de su uso. Esto permite que pueda emplearse como analgésico único, aunque existe controversia en su uso para cirugía ambulatoria de mama. Aporta una mejor analgesia postoperatoria, permitiendo acortar el tiempo de hospitalización tras la cirugía, según varios estudios, en comparación con la anestesia general.

EI BPVT para cirugía mamaria puede ser realizado mediante las diversas modalidades técnicas comentadas previamente. Así, ha sido llevado a cabo en los distintos estudios mediante punción múltiple o bien única, esta última dejando catéter para infusión continua en algunas series. Además, ha sido estudiada y puede ser empleada tanto de forma unilateral como bilateral, bajo control ecográfico y/o neuroestimulación.

Múltiples estudios consideran ventajoso el empleo de bloqueo paravertebral, asociado o no a sedación ligera, frente al empleo de anestesia general en cirugía de mama al menos en términos de inmovilidad por dolor, movilización temprana, estrés quirúrgico, función pulmonar, eventos trombóticos, vómitos postoperatorios, tiempo 
de recuperación, restricción dolorosa al movimiento de los hombros y dolor crónico de herida quirúrgica.

En un trabajo, mejoró la oxigenación en reconstrucción mamaria de lattisimus dorsi. Las escalas de dolor y el consumo de analgésicos fueron menores en el grupo de bloqueo paravertebral en la mayoría de los trabajos [165]. El bloqueo paravertebral también facilita la reintroducción temprana de la dieta y está asociada con una temprana salida del hospital, un alto grado de satisfacción del paciente y podría descender los costes hospitalarios.

Para un bloqueo más completo de la mama será precisa una infiltración subcutánea desde la axila hasta la clavícula para anestesiar las ramas pectorales y cervicales que se dirigen a la zona infraclavicular. Con el fin de evitar un déficit analgésico de los cuadrantes internos, se infiltra subcutáneamente la zona paraesternal con el fin de bloquear las ramas cutáneas anteriores [153].

No obstante, el bloqueo paravertebral sólo presenta ventajas marginales frente a la anestesia general en pacientes sometidas a cirugía menor mamaria como tumorectomía simple, lumpectomía o cuadrantectomía, y el balance riesgo/beneficio no apoya el uso rutinario de esta técnica regional en dichas pacientes [163].

\section{Bloqueo paravertebral y cirugía oncológica mamaria}

El bloqueo paravertebral torácico se ha empleado como adyuvante de la anestesia general en cirugía oncológica de mama con el fin de mejorar la analgesia postoperatoria, utilizándose incluso como sustituto de la misma. En cirugía oncológica de mama está indicada únicamente en cirugías agresivas, no así en biopsia previa localización o tumorectomía sin extirpación de ganglio centinela. Parece que el beneficio es menos patente en cirugías poco agresivas, como se comentó con anterioridad.

Aparte de los beneficios ya comentados en el apartado anterior, el bloqueo paravertebral torácico en cirugía oncológica de mama podría representar una mejora en términos de disminución de la recurrencia tumoral y de aparición de metástasis. En un estudio de seguimiento de 2,5 a 4 años se vio asociado a una reducción de aproximadamente una cuarta parte del riesgo de recurrencia o aparición de metástasis [90].

El bloqueo paravertebral torácico descendió la respuesta al estrés quirúrgico además del consumo de opioides, permitiendo amortiguar los efectos deletéreos de 
ambos sobre las funciones inmunes celulares y humorales. En cáncer mamario, ambas situaciones junto con la reducción en la dosificación de anestésicos volátiles, han sido sugeridos como los factores potencialmente relacionados con la menor incidencia observada en la recurrencia tumoral postcirugía.

No obstante, como ya se ha comentado en un apartado anterior, serán precisos estudios aleatorizados más amplios con un mayor periodo de seguimiento como el que están llevando a cabo Sessler y colaboradores [20,133], para aportar conclusiones definitivas en este sentido.

\subsection{INDOLEAMIN-2,3-DIOXIGENASA}

Los tumores evolucionan constantemente, desarrollando múltiples mecanismos que les confieren capacidad de crecimiento, desarrollo y resistencia a la acción del sistema de defensa y de los distintos tratamientos, aumentando su supervivencia.

Entender la evasión tumoral del sistema inmune continúa constituyendo el centro de numerosas investigaciones. Recientemente, se ha observado que la enzima indoleamin-2,3-dioxigenasa o IDO se encuentra implicada en la aparición y mantenimiento a largo plazo de dicha inmunosupresión tumoral. Varios estudios han identificado a la IDO jugando un papel al bloquear una respuesta más vigorosa del sistema inmune contra el crecimiento tumoral. Su activación conlleva la depleción de triptófano de los tejidos, llevando a la modulación, entre otras cosas, del sistema inmune tanto innato como adaptativo.

\subsubsection{Descripción y función}

La IDO es una enzima extrahepática monomérica de 45 KDa que cataliza el paso inicial y limitante en la degradación del triptófano por la vía de la quinurenina que conduce a la biosíntesis de Nicotinamida-Adenin-Dinucleótido (NAD).

El triptófano es el aminoácido esencial menos abundante. La vía de la quinurenina ha sido ampliamente estudiada, constatando que es la ruta más importante de degradación del mismo en los mamíferos, e influyente en numerosos procesos biológicos. En el primer paso de este proceso metabólico, el triptófano es transformado en quinurenina mediante una reacción catabolizada por dos enzimas: la indoleamin-2,3-dioxigenasa (ID0) y la triptófano-2,3-dioxigenasa (TDO). Los metabolitos resultantes, conocidos colectivamente como quinureninas, han mostrado tomar parte en muchos y diversos procesos fisiológicos y patológicos. Hay un creciente interés en el papel de las quinureninas en la función inmune. 


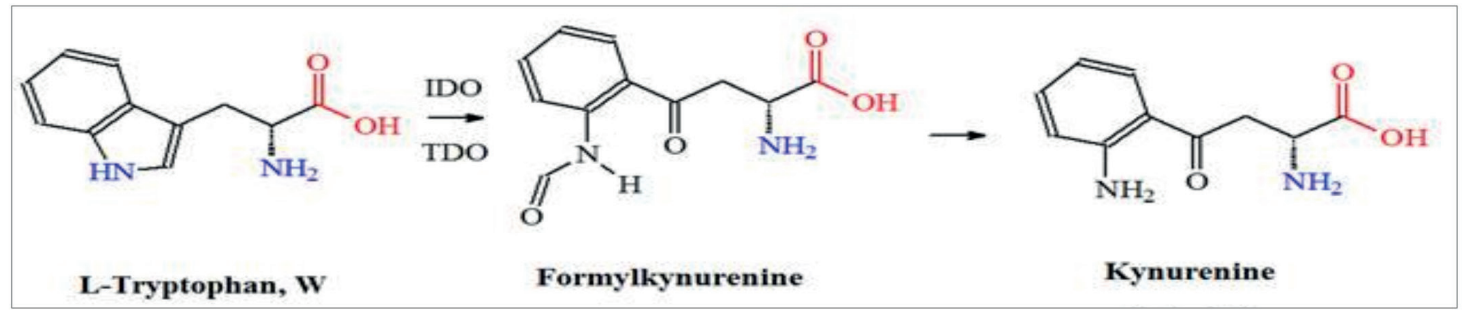

IDO no es sólo un catalizador capaz de suprimir reacciones inflamatorias potencialmente exageradas en respuesta a señales de peligro sino que también es un importante componente de señalización en un sistema de regulación que preside en el control a largo plazo de la homeostasis inmune al activar a las células dendríticas hacia un fenotipo tolerogénico estable, requerido en algunas situaciones tanto fisiológicas, como el embarazo, como patológicas (infección, autoinmunidad, depresión, obesidad, aterosclerosis, transplante y neoplasia), teniendo, por tanto, una importancia médica considerable.

La IDO puede ser expresada intracelularmente tanto de forma constitutiva como de forma inducible en diferentes órganos, como la placenta, pulmones, intestino, bazo, riñones, estómago y cerebro. Además, también su actividad puede ser inducida por IFN-y en células mieloides (dendríticas, monocitos, macrófagos, eosinófilos), células epiteliales, fibroblastos, músculo liso vascular, células endoteliales así como en múltiples tipos de células tumorales [166-168]. Para el presente trabajo nos centraremos en el papel de la desregulación de la actividad de la enzima IDO en el cáncer humano.

\subsubsection{IDO y cáncer}

Basado en la actividad catabólica del triptófano, IDO es considerada como un principio inmunosupresor que genera tolerancia antigénica, pero estudios en ratones genéticamente deficientes indican que la IDO podría actuar de una manera más directa como modificador del microambiente inflamatorio no sólo en enfermedades autoinmunes e infecciones, si no también en el cáncer.

El metabolismo anómalo de triptófano, así como la acumulación de quinurenina en la orina de pacientes con cáncer ya fueron informadas hace más de medio siglo. Múltiples líneas de evidencia incluyen datos que muestran que la IDO se encuentra sobreexpresada en una amplia variedad de tumores (endometrial, mamario, colorrectal, prostático, cervical, pulmonar, oral, ovárico, pancreático y sanguíneos, como leucemia monocítica aguda, leucemia linfocítica aguda, leucemia mieloide aguda y linfoma de Hodgkin infantil) [169-184]. 
Inicialmente, se creía, equivocadamente, que la actividad de IDO conllevaba un efecto inhibitorio sobre los tumores humanos al depleccionarlos del triptófano, aminoácido esencial para su supervivencia. Posteriormente, por el contrario, se propuso un nuevo mecanismo de supresión inmune a nivel local como el potencial mecanismo de acción, en este caso protumoral, de esta enzima. Éste consistía en que la disponibilidad de IDO a partir de varias fuentes del microambiente tumoral ayudaría a las células malignas a evadir la destrucción local inmune al suprimir a los linfocitos reactivos. Desde entonces, este mecanismo se ha ido corroborando a través de numerosos estudios subsecuentes [185].

La evidencia directa apoya la involucración de IDO en el control del crecimiento tumoral a través de una serie de experimentos recientes que demuestran que la expresión ectópica enzimática promueve el crecimiento tumoral en ratones inmunocompetentes, y que, además, estos efectos pueden ser revertidos por una supresión de la actividad de IDO mediante el empleo de inhibidores específicos como el 1-metiltriptófano [186] ó ARNmensajero [187].

De forma característica, en algunos tipos tumorales, como en la neoplasia intraepitelial tipo $\mathrm{CIN}-3$ de cáncer de cuello uterino las células tumorales que expresaban IDO se encontraron situadas principalmente en el borde invasivo del tumor, lo que apoya el mecanismo de inmunosupresión local para evitar la defensa antitumoral, facilitando, de esta manera, el avance tumoral [188].

Añadidamente, parece expresarse no sólo en las células malignas del tumor primario, sino que también las células metastásicas la utilizan, como se mostró en una investigación en adenocarcinoma pancreático ductal metastásico, siendo demostrada incluso una mayor intensidad de la expresión enzimática en las células del foco metastásico cuando se compararon con las células del tumor primario. Estos datos indican que las células metastásicas de cáncer pancreático pueden ser específicamente seleccionadas para la expresión de IDO con el fin de evadir la detección inmune. Es posible encontrar una mayor prevalencia de mecanismos de escape inmune en el foco metastásico que en el tumor primario, lo que indica una mayor presión de selección durante el proceso metastásico.

Todos estos resultados son sugerentes de que la IDO podría tener un papel central no solo en el crecimiento tumoral sino también en la promoción metastásica, ya que las células tumorales positivas para IDO parecen tener un mayor potencial para migrar hacia los ganglios linfáticos frente a las que son IDO-negativas. 
Para complicar más las cosas, la transfección con IDO permite convertir en inmunosupresoras a líneas celulares tumorales que previamente no lo eran, como se ha observado al menos en ciertos tumores como el de pulmón. Además el estudio de Levina et al sugiere que la IDO presenta efectos directos no inmunológicos tras observarse menor crecimiento tumoral de lo esperado en ratones no inmunocompetentes, y mayor apoptosis, así como la desactivación de genes involucrados en el ciclo celular en ratones IDO negativos [189].

\subsubsection{IDO y células inmunes}

Esta enzima no sólo es expresada por las células malignas sino también por las células del microambiente peritumoral y perimetastásico, lo que permite mantener el ambiente de supresión inmune. De esta manera, IDO es expresada por las células mononucleares como los linfocitos infiltrantes del tumor y las células dendríticas de los ganglios linfáticos de drenaje tumoral.

En las células dendríticas, IDO tiene una importancia clave en el mantenimiento sostenido de la supresión inmune. En estas células, IDO tiene al menos dos funciones, aunque es principalmente una enzima que cataliza el triptófano, deprivando así a las células T de nutrición, también puede actuar como un transductor de señal que inicia una serie de eventos moleculares conectados, que envuelven la regulación pro-

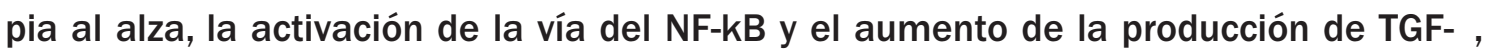
confiriendo en conjunto un fenotipo inmunosupresivo a las propias células dendríticas. Así, estas células dendríticas generan linfocitos Treg que pueden iniciar, sostener y/o amplificar las vías inmunorreguladoras, llevando a una tolerancia inmune de larga duración.

La transferencia de IDO también de una célula dendrítica a otra es muy importante en el mantenimiento a largo plazo de IDO en un microambiente particular a lo largo de un periodo de varios meses, considerando que la vida de una célula dendrítica inmadura varía de unos días a unas semanas, e incluso más corto cuando madura. La exposición de nuevas células dendríticas infiltradas a metabolitos de triptófano depositados o la interacción con células Treg preexistentes inducidas por IDO podría perpetuar y sostener un ambiente con alta cantidad de IDO.

Los metabolitos del triptófano inducen apoptosis selectiva de la subpoblación de linfocitos Th1 a través de la activación de la caspasa-8 y de la liberación de citocromo c desde la mitocondria, además de a través de un proceso mediado por los radicales libres de oxígeno. Esta supresión no se observa en la subpoblación de linfocitos Th2. Las células B y las Natural Killer son también susceptibles a estos compuestos [190]. 
En un modelo animal se mostró que las células mononucleares que invadían los tumores e infiltraban los ganglios linfáticos de drenaje tumoral eran seleccionadas por su capacidad para expresar IDO. En este mismo estudio, las células de carcinoma pulmonar de Lewis promovieron una respuesta inmune más efectiva en la presencia del inhibidor de IDO 1-metiltriptófano llevando a la inhibición de las células tumorales. Así, los datos sugieren que los tumores evaden el sistema inmune al menos en parte a través de la IDO y la inhibición de la IDO lleva a un efecto antitumoral [191].

Otro estudio en cáncer de pulmón de células pequeñas reveló expresión de IDO por los eosinófilos que infiltraban el tumor, y que aquélla y la cuantía de eosinófilos IDO positivos estaban asociados a una supervivencia global acortada [192].

Las conclusiones de diversos autores convergen en que la actividad de IDO podría convertirse en un objetivo apropiado para la valoración del desarrollo de tolerancia a las células $\mathrm{T}$, buscando así una mejor manera de promover una respuesta inmune efectiva contra el cáncer, incluido el de mama [190]. No obstante, también se han encontrado algunos resultados conflictivos, pero, a pesar de ellos, si se confirma el papel de IDO según el tipo tumoral, la amplia mayoría de las investigaciones apoya la involucración de la enzima IDO en la promoción tumoral, principalmente, por supresión de la inmunidad local. Por todo lo mencionado anteriormente, el papel de IDO ha sido considerado lo suficientemente relevante como para desarrollar ensayos clínicos [193].

\subsubsection{IDO y pronóstico oncológico}

En relación a lo anteriormente expuesto, no es sorprendente que diversos estudios hayan puesto de manifiesto que la actividad de esta enzima está envuelta en la progresión del cáncer, correlacionándose con un estadío tumoral avanzado, empeoramiento de la calidad de vida con mayor frecuencia de caquexia y con un mal desenlace clínico llevando a una reducción de la supervivencia tanto global como libre de enfermedad del paciente oncológico. Estos datos también sugieren que la enzima IDO podría ser un nuevo y prometedor marcador pronóstico en el caso de ciertos tumores como el cáncer de endometrio, pudiendo llegar a ser un nuevo objetivo durante el tratamiento del mismo [194-197].

Además, aquellos pacientes oncológicos con elevados niveles de actividad de la enzima IDO presentan una menor infiltración intratumoral de células T, de células NK y eosinófilos, al igual que una gran resistencia farmacológica al tratamiento quimioterápico (por ejemplo, al paclitaxel en carcinoma ovárico) [198]. 
Los resultados observados en múltiples estudios sugieren que el ratio quinurenina/triptófano podría ser un marcador útil de la respuesta o resistencia al tratamiento quimioterápico y, por tanto, de la eficacia del mismo. Así, por ejemplo, Sakurai et al midieron la relación quinurenina/triptófano en mujeres con cáncer de mama recurrente que recibían quimioterapia y compararon los niveles entre dos regímenes diferentes, paclitaxel y docetaxel. Encontraron que las mujeres en tratamiento con docetaxel tenían ratios quinurenina/triptófano más altos postquimioterapia en comparación con aquellas que recibieron paclitaxel, sugiriendo este último como más efectivo para la erradicación tumoral [199-202].

\subsubsection{Inhibidores de IDO}

Con lo expuesto anteriormente la enzima IDO representa una diana ideal para la intervención terapéutica. De esta manera, se están investigado y desarrollando inhibidores de la actividad de IDO, evaluándose tanto en modelos animales como en pacientes, y en conjunto los datos obtenidos han sugerido que los antagonistas de IDO podrían tener utilidad en el tratamiento oncológico. La inhibición de la actividad inapropiada de IDO en los tumores in vivo parece atenuar la capacidad de los tumores para evadir la inmunovigilancia y el aclaramiento tumoral, retrasando intensamente el crecimiento de tumores como el de pulmón, mediante el 1-metiltriptófano [191].

Aunque son varios los grupos que han demostrado que se puede modular el crecimiento tumoral únicamente a través de los inhibidores de IDO, el empleo combinado de estos agentes en combinación con otras formas de inmunomodulación es lo que ha conducido a los resultados más impresionantes. Por ejemplo, la combinación de 1-metiltriptófano con una vacuna de fusión de células tumorales con células dendríticas mejoró aún más las respuestas antitumorales [203]. De forma similar, se ha demostrado recientemente que la inhibición de IDO puede disminuir de forma efectiva la contrarregulación homeostática inducida por tratamiento con interleuquina-12 (IL12). El resultado en estos estudios llegó a la cura completa del $45 \%$ de los tumores establecidos [204].

Además, la inhibición de IDO también mejoró la eficacia de una terapia antitumoral no inmune, aunque el efecto aditivo del 1-metiltriptófano junto a esta pequeña molécula, requirió un receptor inmunocompetente [205].

Por otro lado, el empleo de estos inhibidores de IDO (tanto 1-metiltriptófano como macromoléculas como el small-interference-RNA o siRNA) no sólo reduce significativamente por sí mismo el crecimiento tumoral sino que también potencia los efectos antitumorales de varios agentes citostáticos (como la temozolomida, bisclo- 
roetilnitrosurea, etopósido y cisplatino en células de glioma, o la ciclofosfamida, paclitaxel y gemcitabina en melanoma y cáncer de mama) [206,207].

\subsubsection{IDO y cáncer de mama}

Afirmaciones similares a las anteriores pueden realizarse en el caso del cáncer de mama. No existen demasiados trabajos que investiguen la relación ente IDO y cáncer de mama. Entre otros tipos tumorales, también se ha encontrado evidencia de una expresión incrementada de IDO tanto en el tumor primario como en el suero de pacientes con cáncer de mama [199].

En tumores invasivos ductales y lobulillares, los resultados indican que la expresión de IDO es significativamente mayor en los tumores malignos de mama que en los tejidos mamarios benignos. La expresión de IDO se correlacionó con estados más avanzados de la enfermedad y con una mayor extensión metastásica en los ganglios linfáticos [208].

Estos resultados sugieren que la IDO podría tener un papel central no solo sobre el crecimiento tumoral mamario si no también en la promoción metastásica [209], ya que las células tumorales positivas para IDO parecen tener un potencial mayor para migrar a los ganglios linfáticos que las que son negativas [210,211]. Estos resultados coinciden con informes anteriores en los que la expresión de IDO estaba asociada a una mayor tasa de metástasis a distancia en la clínica en otros tipos tumorales.

Sin embargo, en la literatura también encontramos que Jacquemier et al mostraron un efecto opuesto de la IDO en el cáncer de mama de tipo medular, un subtipo basal-like diferente del carcinoma invasivo, en el que la expresión elevada de IDO en células epiteliales o estromales estaba asociada a una gran cantidad de infiltrado linfoide y a un pronóstico más favorable de las pacientes, aunque este efecto se observó exclusivamente en los tumores de tipo medular y no en otros. Así, la discrepancia observada puede ser atribuida al subtipo diferente de tumor mamario examinado [212].

Al igual que en otros tumores, también se investigó la inhibición de IDO empleando células tumorales de mama en ratones transgénicos, y se observó que fue menos efectiva al realizarse de forma aislada que cuando se combinó con varios agentes quimioterapeúticos [206]. Además, mostró que la actividad antitumoral de IDO parece ser mediada por células T, ya que el efecto se abolió al depleccionar a los sujetos de células CD4 o CD8 previamente al tratamiento. 
De forma consistente con estudios previos, las mujeres con cáncer de mama tuvieron menores niveles de quinurenina y de la relación quinurenina/triptófano tras el cese de la quimioterapia [199], aunque siguieran descendiendo los niveles de triptófano. Aunque en el presente estudio no se puede hacer ninguna inferencia acerca de la efectividad de la quimioterapia, los resultados observados en anteriores estudios sugieren que el ratio quinurenina/triptófano podría ser un marcador útil de la eficacia del tratamiento. En este tipo tumoral los autores proponen que el ratio quinurenina/ triptófano podría ser un marcador útil de la eficacia del tratamiento. Los autores concluyen que nuevas terapias centradas en IDO podrían proveer una nueva dirección para el tratamiento del cáncer de mama.

Los resultados de estos trabajos apoyan la necesidad de una mayor investigación de la degradación del triptófano como un mecanismo biológico potencial en el desarrollo de síntomas y desenlace en el cáncer de mama.

\subsection{RATIO NEUTRÓFILOS/LINFOCITOS Y CÁNCER}

Hoy es ampliamente reconocido que el desenlace de los pacientes no están únicamente determinadas por las características tumorales, sino que los factores relacionados con el paciente también son clave. La inflamación asociada al cáncer es un determinante clave de la progresión de la enfermedad y supervivencia en la mayoría de tumores [247].

\subsubsection{Descripción y función}

Ante la creciente evidencia del papel de la inflamación en la biología tumoral, la respuesta inflamatoria a nivel sistémico ha sido postulada como un factor pronóstico significativo en un amplio rango de diferentes tipos de cáncer.

La diferencia relativa entre el contaje de neutrófilos y linfocitos, o Ratio Neutrófilos/Linfocitos (NLR), ha atraído el interés de los investigadores como un marcador emergente de la inflamación sistémica subyacente por encima de una amplia variedad de marcadores bioquímicos y hematológicos, no solo por ser simple y reproducible, sino también por ser coste-efectivo, de rápida obtención formando parte de los exámenes rutinarios, siendo asequible para la evaluación clínica tanto pre como postratamiento.

Aunque se han identificado nuevos biomarcadores específicos, la mayoría supone invertir demasiado tiempo y/o dinero, además de requerir de técnicas especiales [221-228]. 
Se le ha propuesto, además, un papel en la identificación de pacientes de alto riesgo tanto en el ámbito oncológico como fuera de él (cardiaco, sepsis por ejemplo), dada su gran correlación con la respuesta inflamatoria [255-258].

Esta ratio está asociada a la gravedad y estadio de la enfermedad oncológica y, recientemente, la evidencia sobre el papel predictivo de la ratio Neutrófilos/Linfocitos en diferentes procesos inflamatorios como eventos cardiovasculares, sepsis, además de la respuesta al tratamiento quirúrgico oncológico y quimioterápico ha aumentado.

\subsubsection{Ratio Neutrófilos/Linfocitos y cáncer}

La ratio Neutrófilos/Linfocitos no solo ha sido estudiada en cuanto a su capacidad diagnóstica, sino que también es uno de los marcadores inflamatorios más estudiados en cuanto al desenlace oncológico. Seretis et al observaron que en pacientes operados de tiroides, la elevación preoperatoria del ratio predecía la presencia de microcarcinoma papilar de tiroides [259]. De forma similar, en pacientes operadas de patología mamaria, se detectó una ratio preoperatoria elevada en aquellas pacientes que presentaban cáncer de mama en comparación con el valor en pacientes que presentan enfermedad proliferativa benigna de la mama [250].

La ratio Neutrófilos/Linfocitos es uno de los marcadores inflamatorios más estudiados, en numerosos tipos de cáncer. Distintos estudios y metanálisis de los mismos han destacado el papel de un valor elevado como herramienta preoperatoria para la detección de los pacientes oncológicos con peor pronóstico, en términos de comorbilidades, supervivencia total y supervivencia libre de enfermedad, asociándose con perfiles tumorales más agresivos. Un valor pretratamiento o preoperatorio elevado ha sido identificado como un factor pronóstico independientemente asociado con baja supervivencia en varios tumores, incluyendo cáncer de mama, de colon, de pulmón y mesotelioma entre otros $[215,216,218,263]$.Diversos metanálisis han reforzado estos resultados [221-228]. Más aún, algunos estudios lo han identificado como una herramienta válida para identificar el grado de sensibilidad de los pacientes a un régimen específico de quimioterapia [234], pudiendo ser empleado tanto en el ámbito quirúrgico como fuera de él [247].

Otros estudios se focalizan en la tendencia que presenta la ratio durante la historia tumoral, mostrando que un valor persistentemente alto se asocia con un pronóstico desfavorable, reflejando la variación dela ratio Neutrófilos/Linfocitos entre el preooperatorio y el postoperatorio el cambio dinámico entre la respuesta inflamatoria tumoral y el estado inmune del huésped que aparece en el periodo perioperatorio. Va- 
rios estudios muestran esta variación como un factor pronóstico independiente para la supervivencia global y supervivencia libre de recurrencia en distintos tumores como hepático, colónico, renal y gástrico [254,255]. Algunos de ellos tras la cirugía de resección, y otros tras la cirugía y quimioterapia [217]. En términos generales, el aumento del ratio Neutrófilos/Linfocitos fue constante en el grupo con peor evolución. Estos datos muestran la importancia del equilibrio entre la respuesta inflamatoria sistémica y la respuesta inmune, y cómo puede cambiar tras la resección tumoral quirúrgica, llevando a un diferente pronóstico. Para algunos autores el fallo en el descenso de su valor postcirugía supone, así, la formación de un sustrato inflamatorio en el huésped que favorecería la progresión y el crecimiento tumoral [253].

La relación entre el ratio Neutrófilos/Linfocitos y el pronóstico oncológico no es sencilla de explicar, y los mecanismos precisos subyacentes aún no están claros, pudiendo existir varias posibles explicaciones. La elevación de su valor representaría una linfocitopenia relativa, pudiendo mostrar una menor respuesta inmune antitumoral mediada por linfocitos, favoreciendo la respuesta inflamatoria protumoral. Los linfocitos poseen papeles cruciales en la muerte celular $\mathrm{x}$ citotoxicidad y producción de citoquinas que inhiben la proliferación y actividad metastásica de las células tumorales [231]. En consecuencia, los pacientes con una menor infiltración tumoral linfocítica presentan un peor pronóstico, como ha sido demostrado [222]. Es, además, bien conocido que los linfocitos circulantes juegan un importante papel inmunológico en distintos carcinomas. De forma añadida, se ha detectado una fuerte correlación entre la progresión tumoral y la linfopenia en tumores como el renal de células claras [225]. Por el contrario, el recuento linfocitario descendió con la quimioterapia en pacientes con progresión tumoral [255].

Por otro lado, el incremento relativo de neutrófilos circulantes podría incrementar los niveles de factores angiogénicos, de crecimiento, y proteasas que son importantes contribuyentes a la angiogénesis tumoral. Se ha demostrado que la infiltración peritumoral por neutrófilos puede estimular la angiogénesis por liberación de metaloproteinasa de matriz 9 y favorecer la invasión de células tumorales por la producción de factores de crecimiento como el VEGF [221].

Un descenso del ratio, indicaría una mayor respuesta antitumoral. Independientemente del tipo tumoral y el régimen de quimioterapia recibido, se ha observado que la linfocitosis ocurre en pacientes que logran una regresión tumoral tras la quimioterapia, siendo el recuento linfocitario significativamente mayor que el observado antes del inicio del tratamiento [234]. Todo esto sugiere una probable conexión directa entre la biología tumoral y la inflamación sistémica. Así, la variación en el ratio Neutrófilos/ Linfocitos puede ser empleada para predecir la supervivencia y la recurrencia tumoral tras resección curativa, teniendo valor para la toma de decisiones. Su empleo podría 
ser relevante para conocer de forma temprana los efectos de terapias sistémicas. La suspensión precoz de un tratamiento inefectivo para introducir un tratamiento que sí sea eficaz permite elimina toxicidad innecesaria mejorando la calidad de vida de los pacientes.

\subsubsection{Ratio Neutrófilos/Linfocitos y cáncer de mama}

Aunque los estudios que examinan el ratio Neutrófilos/Linfocitos en el cáncer de mama han sido relativamente pocos, han sido consistentes en la asociación de los valores pretratamiento con desenlaces negativos. Los autores de un metanálisis en 2015 en relación al valor de la ratio Neutrófilos/Linfocitos y cáncer de mama concluyen que está asociado a un empeoramiento del pronóstico [215,218 231,247$250,253,263]$. 
NIVELES PERIOPERATORIOS DE QUINURENINA: EFECTOS DE LA ANESTESIA GENERAL VS REGIONAL 
NIVELES PERIOPERATORIOS DE QUINURENINA: EFECTOS DE LA ANESTESIA GENERAL VS REGIONAL 
Con una incidencia en incremento a pesar de las notables mejoras en los tratamientos, el cáncer continúa presentando elevadas tasas de morbimortalidad [8,9], siendo la recurrencia y aparición de metástasis sus principales causas [20]. Éste es el caso de tumores como el de mama, principal causa de cáncer en las mujeres [9]. La evolución tumoral y formación de metástasis depende, entre otras causas, del equilibrio entre el sistema inmune del huésped y la propia habilidad tumoral de sobrevivir e invadir los tejidos [48,49,125,132], demostrándose en los últimos años el poder predictor de supervivencia y de respuesta al tratamiento por parte de ciertos marcadores de inflamación sistémica como la indoleamin-2.3-dioxigenasa (ID0) $[171,173,184,211]$ y la ratio Neutrófilos/Linfocitos (NLR) [221,225,228-235,238,239,242].

La curación de los tumores sólidos pasa habitualmente por someterse a una intervención quirúrgica, no obstante, investigaciones previas han sugerido que el periodo perioperatorio es un momento crucial en la evolución tumoral al observar que existe una serie de factores durante ese periodo responsables de alterar la función del sistema inmune rompiendo el equilibrio al favorecer la formación de metástasis a pesar de una cirugía exitosa [20]. Dentro de ellos se incluyen la respuesta inflamatoria asociada a la cirugía, el dolor agudo, la anestesia en sí misma y la analgesia opioide $[28,109,214]$

Las técnicas locorregionales para el control del dolor intra y postoperatorio se han mostrado de manera reiterada atenuadoras de la respuesta neuroendocrina asociada al estrés quirúrgico, y por tanto, de la inmunosupresión perioperatoria, siendo capaces, además, de reducir la cantidad de anestesia general requerida aportando excelente analgesia y reduciendo el consumo de opioides. Comparadas con la anestesia general, atenuaron el crecimiento de las metástasis tumorales de adenocarcinoma mamario inoculadas en animales $[109,125]$ y recientes investigaciones retrospectivas en humanos indican que están asociadas a una reducción de la recurrencia y metástasis en cirugía de cáncer de mama y próstata [90,91], llevando estos hallazgos a la generación de la hipótesis de que el empleo de analgesia paravertebral podría reducir la incidencia de metástasis y recurrencia en cáncer de mama, comparada con la anestesia estándar con agentes volátiles y opioides, dato que está siendo evaluado actualmente en un ensayo clínico aleatorizado [20].

A pesar de los esfuerzos realizados, existe escasa evidencia acerca de los mecanismos que están detrás del impacto de la técnica anestésica sobre la formación de metástasis, cuyo conocimiento permitiría el desarrollo de fármacos o técnicas que contribuyeran a fortalecerlos y a realizar bloqueos nerviosos más eficaces. La analgesia epidural frente a la anestesia general redujo el número de neutrófilos y aumentó el de linfocitos [246] de igual manera que se ha observado que la analgesia paravertebral reduce la concentración de factores angiogénicos [49], además de reducir la 
proinflamatoria interleuquina 10 (IL-10). Sin embargo, no ha podido demostrarse que reduzca otros mediadores inflamatorios implicados [48] en la promoción tumoral.

Aunque la modificación de la actividad IDO haya sido estudiada en pacientes bajo anestesia general [213] y haya sido mostrada una reducción de la ratio Neutrófilos/Linfocitos (NLR) con anestesia intravenosa total (TIVA) [53], ninguna investigación ha valorado el impacto de la analgesia regional paravertebral frente a la analgesia opioide convencional en pacientes sometidas a cirugía oncológica de mama. 
NIVELES PERIOPERATORIOS DE QUINURENINA: EFECTOS DE LA ANESTESIA GENERAL VS REGIONAL 
NIVELES PERIOPERATORIOS DE QUINURENINA: EFECTOS DE LA ANESTESIA GENERAL VS REGIONAL 
Nuestra hipótesis consiste en que como consecuencia del empleo de analgesia paravertebral torácica en cirugía oncológica mamaria unilateral la actividad sanguínea de la enzima indoleamin-2,3-dioxigenasa (IDO) y el ratio Neutrófilos/Linfocitos serán menores cuando se comparan con el empleo de morfina. 
NIVELES PERIOPERATORIOS DE QUINURENINA: EFECTOS DE LA ANESTESIA GENERAL VS REGIONAL 
NIVELES PERIOPERATORIOS DE QUINURENINA: EFECTOS DE LA ANESTESIA GENERAL VS REGIONAL

4. OBJETIVOS 
NIVELES PERIOPERATORIOS DE QUINURENINA: EFECTOS DE LA ANESTESIA GENERAL VS REGIONAL 


\subsection{OBJETIVO PRINCIPAL}

Este estudio se diseñó para valorar si el empleo del bloqueo analgésico a nivel paravertebral modifica los valores basales preoperatorios de actividad de la enzima proinflamatoria Indoleamin-2,3-Dioxigenasa y los marcadores de inflamación sistémica en el perioperatorio de cirugía oncológica mamaria.

\subsection{OBJETIVOS SECUNDARIOS}

- Definir las características de la muestra.

- Analizar las necesidades analgésicas de las pacientes que reciben anestesia con técnicas regionales frente pacientes que reciben opioides.

- Definir los cambios sanguíneos de actividad de la enzima Indoleamin-2,3-dioxigenasa en el postoperatorio de pacientes de cirugía oncológica mamaria.

- Definir los cambios en la ratio Neutrófilos/LInfocitos en el postoperatorio de pacientes de cirugía oncológica mamaria. 
NIVELES PERIOPERATORIOS DE QUINURENINA: EFECTOS DE LA ANESTESIA GENERAL VS REGIONAL 
NIVELES PERIOPERATORIOS DE QUINURENINA: EFECTOS DE LA ANESTESIA GENERAL VS REGIONAL 


\subsection{DISEÑO DEL ESTUDIO}

Se trata de un estudio clínico, prospectivo de cohortes y simple ciego. No se consideró ético el doble ciego puesto que la técnica paravertebral no es inocua. Fue llevado a cabo en los hospitales General Yagüe y Universitario de Burgos durante el periodo comprendido entre enero de 2011 y febrero de 2015. El mismo equipo de anestesiólogos y cirujanos llevaron a cabo todos los procedimientos. Todos excepto uno de los bloqueos paravertebrales fueron llevados a cabo por el mismo anestesiólogo. Todas las pacientes completaron el estudio de acuerdo al protocolo.

El protocolo del estudio fue aprobado por el Comité Ético del Hospital. Todas las pacientes fueron informadas preoperatoriamente y firmaron un consentimiento de participación en la investigación. Este trabajo ha sido financiado con fondos de investigación de Caja de Burgos/La Caixa (Número de proyecto 60573).

Las pacientes fueron reclutadas con los siguientes criterios:

\subsubsection{Criterios de inclusión:}

Mujeres mayores de 18 años con cáncer de mama diagnosticado por el Servicio de Anatomía Patológica tras biopsia, sometidas de forma programada a tumorectomía o mastectomía con o sin linfadenectomía axilar.

\subsubsection{Criterios de exclusión:}

- Negativa de la paciente.

- Paciente sometida a tumorectomía simple.

- Presencia de coagulopatía.

- Enfermedad pulmonar.

- Alergia a los fármacos que se deben emplear.

- Situación diferente a ASA I-II.

- Contraindicación al uso de la técnica de anestesia paravertebral o al uso de opioides. 
- Cirugía en los 15 días previos.

- Quimioterapia o radioterapia previas.

- Transfusión intraoperatoria.

\subsection{TÉCNICAS Y TRATAMIENTOS RECIBIDOS}

Las pacientes fueron divididas en dos grupos según la técnica analgésica recibida:

-grupo A: recibió analgesia con morfina.

-grupo B: recibió analgesia con catéter paravertebral.

La cirugía y las técnicas anestésicas y analgésicas no diferían de otros procedimientos ordinarios. Todas las pacientes fueron sometidas a anestesia general tras monitorización básica (pulsioximetría, electrocardiograma de dos derivaciones, y tensión arterial no invasiva-monitor Philips Intellivue MX800 y Dräger Infinity XL) según el siguiente protocolo: Inducción anestésica con propofol (PROPOFOL LIPURO ${ }^{\circledR}$, B.Braun) 1-2 mg/kg, fentanilo (FENTANEST ${ }^{\circledR}$, KERN Pharma) $2-4 \mathrm{mcg} / \mathrm{kg}$, rocuronio (ESMERON ${ }^{\circledR}$, MSD) $0,6 \mathrm{mg} / \mathrm{kg}^{\circ}$ o cisatracurio (NIMBEX ${ }^{\circledR}$, GlaxoSmithkline) $0,1 \mathrm{mg} / \mathrm{kg}$. El mantenimiento anestésico se realizó con sevoflurano (SEVORANE ${ }^{\circledR}$, Abbvie) 1 CAM y una mezcla de aire/oxígeno al $50 \%$, ondansetrón (YATROX ${ }^{\circledR}$, Qualigen S.L.) 4 mg, y paracetamol (PERFALGAN ${ }^{\circledR}$, Bristol-Myers-Squibb) + AINE: metamizol (NOLOTIL ${ }^{\circledR}$, Boehringer Ingelheim) o dexketoprofeno (ENANTYUM ${ }^{\circledR}$, Laboratorios Menarini) para la analgesia postoperatoria.

El grupo OPIOIDE recibió 0,1-0,15 mg/kg de morfina (MORFINA BBRAUN ${ }^{\circledR}$, B. Braun) intraoperatoriamente para conseguir analgesia postoperatoria $y$, en caso de precisarlo, una infusión intravenosa continua de morfina a 0,1- 0,15 mg/kg/hora. El grupo PARAVERTEBRAL fue sometido a analgesia regional intraoperatoria y postoperatoria mediante bloqueo nervioso paravertebral con punción en el cuarto espacio torácico (T4) y a través de un catéter número 20G (Perifix ONE ${ }^{\circledR}$, B.Braun), que se colocó mediante técnica estándar de forma previa a la inducción anestésica. Tras aspiración con jeringa a través del catéter sin salida de sangre, se inyectó una dosis test de 3 mililitros $(\mathrm{ml})$ de bupivacaína al $0,25 \%$ con vasoconstrictor (INIBSACAIN ${ }^{\circledR}$, Laboratorios INIBSA). Si hubo sangrado se retiró 1 centímetro el catéter y se volvió a comprobar sangrado. Si la inyección de la dosis test resultó negativa (no produciéndose taquicardia ni bloqueo intradural) se añadieron 8 a $10 \mathrm{ml}$ de ropivacaína al 0,5\% (NAROPIN POLYAMP ${ }^{\circledR}$, ASTRA ZENECA) a través del catéter, según el número de metámeras y 
tamaño de la paciente. Postoperatoriamente se mantuvo una infusión continua de ropivacaína al 0,15 \% a 8-10 $\mathrm{ml} /$ hora a través de dicho catéter. En caso de fallo completo del bloqueo (definido como altos requerimientos de analgesia suplementaria, excluyendo anestesia local) los pacientes comenzaron con morfina como el grupo de Anestesia General.

Tras finalizar la cirugía, todas las pacientes fueron conducidas a la Unidad de Reanimación, donde recibieron tratamientos, monitorización y cuidados estándar. Las pacientes fueron dadas de alta de la Unidad de acuerdo a los criterios habituales. El nivel de dolor fue evaluado mediante la Escala Visual Analógica (EVA) en la Unidad de Reanimación y a las 6 horas postoperatorias.

\section{- Escala Visual Analógica}

Escala objetiva de valoración del dolor con rango variable desde 0 hasta 10.

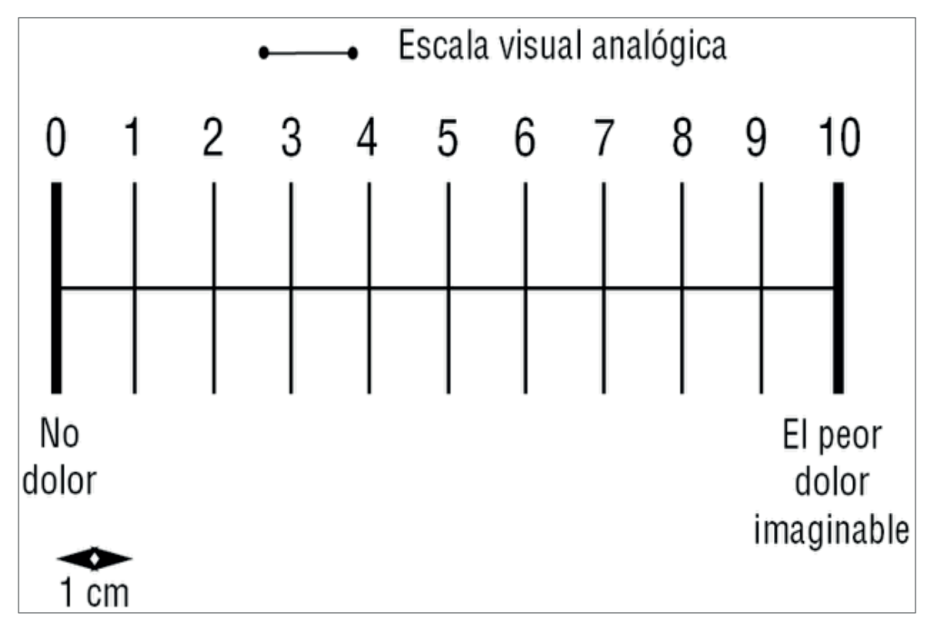

Figura 13. Escala Visual Analógica

Se consideró que la analgesia era adecuada cuando el valor de EVA fue menor o igual a 3. 


\subsection{DEFINICIONES}

\subsubsection{Clasificación ASA [106]:}

La clasificación de la Sociedad Americana de Anestesiólogos (ASA) ordena los pacientes de acuerdo a su riesgo anestésico (Tabla IV). Cuanto mayor es su valor, mayor es el riesgo de complicaciones.

Tabla IV. Clasificación del estado físico de la American Society of Anesthesiologists (Sociedad Americana de Anestesiólogos)

\begin{tabular}{|l|l|}
\hline ASA & Características \\
\hline I & Sin problemas orgánicos, fisiológicos o psiquiátricos \\
\hline II & $\begin{array}{l}\text { Afecciones médicas controlodas con efectos } \\
\text { sistématicos leves, sin limitación de la capacidad } \\
\text { funcional }\end{array}$ \\
\hline III & $\begin{array}{l}\text { Afecciones médicas con efectos sistématicos } \\
\text { importantes, limitación de la capacidad funcional }\end{array}$ \\
\hline IV & $\begin{array}{l}\text { Afecciones médicas mal controladas asociadas a } \\
\text { deterioro significativo de la capaciddad funcional, } \\
\text { con riesgo vital }\end{array}$ \\
\hline V & $\begin{array}{l}\text { Estado crítico, escasos cambios en la tasa de supervi- } \\
\text { vencia sin cirugía }\end{array}$ \\
\hline VI & Muerte cerebral \\
\hline U & Urgencia, traumatismo \\
\hline
\end{tabular}

\subsubsection{Estadiaje tumoral}

La clasificación más comúnmente empleada es la TNM, comentada en el apartado Introducción. La presencia de metástasis ganglionares axilares constituye el factor pronóstico de mayor importancia. 


\subsubsection{Variedad histológica tumoral}

Los tipos tumorales incluidos en el estudio son el carcinoma ductal infilltrante y el carcinoma lobulillar, los tipos más frecuentemente encontrados en nuestro medio. Su pronóstico es similar. Otros tipos histológicos como el tubular, intraductal, medular, coloide, papilar, y adenoquístico están asociados a mejor pronóstico, siendo los inflamatorios y los carcinosarcomas las variedades más agresivas.

\subsubsection{Grado de diferenciación histológica}

Indica la virulencia o agresividad del tipo tumoral analizado. Se obtiene mediante microscopía óptica. A mayor grado, mayor agresividad tumoral y, por tanto, mayor probabilidad de metastatización. La tabla $\mathrm{V}$ muestra los grados que se pueden distinguir, según la clasificación de la OMS [10].

Tabla V. Grado de diferenciación histológica

\begin{tabular}{|l|l|}
\hline GRADO & DIFERENCIACIÓN HISTÓLOGICA \\
\hline I & Bien diferenciado \\
\hline II & Moderadamente diferenciado \\
\hline III & Indeferenciación \\
\hline
\end{tabular}

\subsubsection{Tipo de intervención quirúrgica}

Las técnicas quirúrgicas que se incluyeron fueron:

- Snoll (Tumorectomía + búsqueda selectiva del ganglio centinela ó linfadenectomía axilar homolateral).

- Tumorectomía + linfadenectomía axilar homolateral.

- Mastectomía simple.

- Mastectomía + búsqueda selectiva del ganglio centinela.

- Mastectomía + linfadenectomía axilar homolateral. 


\subsubsection{Transfusión de hemoderivados}

Número de unidades de sangre transfundidas en el perioperatorio.

\subsubsection{Actividad IDO}

El análisis de la actividad IDO se realizó tras extracción sanguínea mediante venopunción periférica en cuatro momentos: de forma previa a la inducción anestésica, tras extracción de la pieza quirúrgica, y, por último, a los 30 minutos y 6 horas postoperatoriamente. La sangre fue transportada en un tubo morado (BD Vacutainer).

A partir de $\mathbf{2 0 0}$ microlitros de la muestra se precipitaron las proteínas con 100 microlitros de ácido tricloroacético. Se incubó a $100^{\circ} \mathrm{C}$ durante 10 minutos, y se centrifugó 10 minutos a $2500 \mathrm{~g}$. La concentración de quinurenina se determinó mediante cromatografía líquida de alta precisión (HPLC) usando una columna Waters C18 (4,5 $\mathrm{mm} \times 15 \mathrm{~cm}$ ). Como fase móvil se utilizó tampón acetato de sodio $15 \mathrm{mM}, \mathrm{pH} 4$ y acetonitrilo $2,7 \%$. La absorbancia se midió a $360 \mathrm{~nm}$ y la concentración de quinurenina se expresó en microM [202].

\section{- Preoperatoria}

La muestra sanguínea fue obtenida en quirófano previamente a la realización del bloqueo paravertebral y/o inducción anestésica.

- Intraoperatoria

La muestra sanguínea fue obtenida en quirófano tras la extracción de la pieza quirúrgica y antes de suspender la medicación anestésica.

\section{- Postoperatoria}

La primera muestra sanguínea postoperatoria fue obtenida a los 30 minutos de la retirada de medicación anestésica, en la Unidad de Reanimación. La segunda muestra postoperatoria fue recogida a las 6 horas de la retirada de la medicación anestésica, en la planta de hospitalización.

\subsubsection{Fórmula leucocitaria}

Se extrajeron por venopunción $3 \mathrm{ml}$ de sangre y se transfieron a un tubo morado (BD Vacutainer). El perfil hemático completo, incluyendo la formula leucocitaria 
total y diferencial fue medida empleando un contador automático XE-5000 (SYSMEX, Vietnam).

\subsection{VARIABLES DEL ESTUDIO}

\subsubsection{Variables principales}

La variable principal del estudio es la actividad sanguínea de la enzima Indoleamin-2,3-Dioxigenasa medida como nivel de quinurenina.

\subsubsection{Variables independientes}

Edad; Patología coexistente, hipertensión arterial, obesidad, diabetes mellitus, dislipemia, hipotiroidismo. Tipo tumoral, tipo tumoral, presencia de receptores estrogénicos, presencia de receptores de progesterona, presencia de Her2, grado de diferenciación histológica, metástasis; Tipo de cirugía; Tipo de analgesia, morfina, paravertebral; peso de pieza quirúrgica; Curso intraoperatorio, duración de la intervención quirúrgica; volumen de líquidos administrados, dosis total de morfina, dosis total fentanilo; Medidas de inflamación sistémica, ratio Neutrófilos/Linfocitos.

\subsection{ANÁLISIS ESTADÍSTICO}

El análisis se realizó con el programa IBM SPSS (Statistical Package for the Social Sciences), versión 19. Se consideró como significación estadística aquel valor $p<$ 0,05 . Se realizó la prueba t de Student para comparar las diferencias de las variables cuantitativas según el grupo, y una prueba no paramétrica (U de Mann-Whitney) para la variables que no seguían una distribución normal.

Para las variables cualitativas se realizaron tablas de contingencia y las comparaciones se realizaron según el estadístico oportuno en cada caso (Fisher, Chi-cuadrado, $\mathrm{V}$ de Cramer) 
NIVELES PERIOPERATORIOS DE QUINURENINA: EFECTOS DE LA ANESTESIA GENERAL VS REGIONAL 
NIVELES PERIOPERATORIOS DE QUINURENINA: EFECTOS DE LA ANESTESIA GENERAL VS REGIONAL

6. RESULTADOS 
NIVELES PERIOPERATORIOS DE QUINURENINA: EFECTOS DE LA ANESTESIA GENERAL VS REGIONAL 


\subsection{CARACTERÍSTICAS CLÍNICAS Y DEMOGRÁFICAS DE LAS PACIENTES}

Durante el periodo indicado, un total de 75 pacientes reunieron los criterios para la inclusión en el estudio, no obstante, 2 pacientes rechazaron la participación, en 1 paciente hubo dificultades para la colocación del catéter y en 2 pacientes no funcionó correctamente el catéter por lo que fueron sacadas del estudio. En total, el estudio incluyó 70 pacientes, 38 dentro del grupo que recibió morfina y 32 dentro del grupo con analgesia paravertebral.

La Tabla VI recoge los datos demográficos de las pacientes. La mediana de edad de las 32 pacientes que recibieron analgesia paravertebral fue de 62,5 años, y en el grupo de analgesia con morfina fue de 56,5 años, no existiendo diferencias significativas entre ambos grupos.

La distribución de las técnicas quirúrgicas realizadas se muestra en la Tabla VII según los diferentes grupos. Ambos grupos de analgesia estaban bien balanceados a este respecto.

En el grupo paravertebral la duración media de la intervención quirúrgica fue de 112,5 minutos y en el grupo morfina fue la misma siendo ambos grupos comparables. Tampoco hubo diferencias entre el peso de la pieza quirúrgica y los líquidos administrados entre los grupos (Tabla VIII).

Tabla VI. Datos demográficos y patología coexistente de la población a estudio

\begin{tabular}{|l|l|l|l|}
\hline Características & Morfina $(\mathrm{n}=38)$ & Paravertebral $(\mathrm{n}=32)$ & Valor $\mathbf{p}$ \\
\hline Edad, años, & $62,5(50,5-74,25)$ & $56,5(48,25-73)$ & 0,351 \\
\hline Hipertensión, $\mathrm{n}(\%)$ & $12(17,1)$ & $6(8,6)$ & 0,221 \\
\hline Dislipemia, $\mathrm{n}(\%)$ & $9(12,9)$ & $6(8,6)$ & 0,616 \\
\hline Hipotiroidismo, $\mathrm{n}(\%)$ & $3(4,3)$ & $4(5,7)$ & 0,522 \\
\hline Diabetes, $\mathrm{n}(\%)$ & $3(4,3)$ & $1(1,4)$ & 0,392 \\
\hline
\end{tabular}

Los valores son expresados en número (porcentaje) o como mediana y rango intercuartílico. El valor de probabilidad, $p \leq 0.05$, era considerado como significativo. 
Tabla VII. Tipos de intervención quirúrgica

\begin{tabular}{|l|l|l|l|}
\hline Características & Morfina $(\mathrm{n}=38)$ & Paravertebral $(\mathrm{n}=32)$ & Valor $\mathbf{p}$ \\
\hline Tipo de intervención & & & 0,843 \\
Snoll, $\mathrm{n}(\%)$ & $28(73,7)$ & $21(65,6)$ & \\
$\begin{array}{l}\text { Mastectomía simple } \\
\mathrm{n}(\%)\end{array}$ & $1(2,6)$ & $2(6,3)$ & \\
Mastectomía + & & $6(18,8)$ & \\
linfadenect, $\mathrm{n}(\%)$ & $6(15,8)$ & $3(9,4)$ & \\
Linfadenect, $\mathrm{n}(\%)$ & $3(7,9)$ & & \\
\hline
\end{tabular}

Los valores son expresados en número (porcentaje) o como mediana y rango intercuartílico. El valor de probabilidad, $p \leq 0.05$, era considerado como significativo.

Tabla VIII. Características intraoperatorias

\begin{tabular}{|l|l|l|l|}
\hline Características & Morfina $(\mathrm{n}=38)$ & Paravertebral $(\mathrm{n}=32)$ & Valor $\boldsymbol{p}$ \\
\hline $\begin{array}{l}\text { Peso pieza qgca, } \\
\text { gramos }\end{array}$ & $123(46-245)$ & $104,5(51-582)$ & 0,768 \\
\hline $\begin{array}{l}\text { Duración IQ, } \\
\text { minutos }\end{array}$ & $112,5(93,75-125,25)$ & $112,5(91,25-150)$ & 0,745 \\
\hline $\begin{array}{l}\text { Líquidos } \\
\text { administrados } \\
\text { - hasta } 750 \mathrm{ml} \\
\text { - más de } 750 \mathrm{ml}\end{array}$ & $\begin{array}{l}18(25,7) \\
20(28,6)\end{array}$ & $\begin{array}{l}17(24,3) \\
15(21,4)\end{array}$ & 0,631 \\
\hline
\end{tabular}

Los valores son expresados en número (porcentaje) o como mediana y rango intercuartílico. El valor de probabilidad, $p \leq 0.05$, era considerado como significativo. 
Comparando las necesidades analgésicas de opioides entre el grupo con morfina intravenosa y el grupo con analgesia a través de bloqueo paravertebral, se observó una reducción significativa de la mismas en este último tanto de fentanilo como de morfina (Tabla IX).

Tabla IX. Dosis empladas de analgésicos opioides

\begin{tabular}{|l|l|l|l|}
\hline Características & Morfina $(\mathrm{n}=38)$ & Paravertebral $(\mathrm{n}=32)$ & Valor $\boldsymbol{p}$ \\
\hline $\begin{array}{l}\text { Dosis fentanillo, } \\
\text { microgr }\end{array}$ & $350(300-450)$ & $150(150-250)$ & $<0,001^{\star}$ \\
\hline Dosis morfina, mg & $6(2-8)$ & $1(0-2)$ & $<0,001^{\star}$ \\
\hline
\end{tabular}

Los valores son expresados en número (porcentaje) o como mediana y rango intercuartílico. El valor de probabilidad, $p \leq 0.05$, era considerado como significativo.

La Tabla $\mathrm{X}$ detalla las características de los tumores resecados, dentro de ellas se encuentran el tipo tumoral, el grado de diferenciación tumoral, presencia de receptores estrogénicos, presencia de receptores de progesterona, presencia de HER2 y positividad de ganglio centinela en los grupos analizados. Entre ambos grupos de tratamiento analgésico no se encontraron diferencias estadísticamente significativas (Tabla X). 
Tabla X. Características anatomía patológica

\begin{tabular}{|l|l|l|l|}
\hline Características & Morfina (n=38) & Paravertebral (n=32) & Valor $\mathbf{p}$ \\
\hline $\begin{array}{l}\text { Tipo tumoral } \\
\text { Ductal, } \mathrm{n}(\%) \\
\text { Lobulillar, } \mathrm{n}(\%)\end{array}$ & $\begin{array}{l}33(86,8) \\
5(13,2)\end{array}$ & $\begin{array}{l}30(93,8) \\
2(6,3)\end{array}$ & 0,337 \\
\hline $\begin{array}{l}\text { Grado histológico } \\
\text { Grado I, n (\%) } \\
\text { Grado II, n (\%) } \\
\text { Grado III, n (\%) }\end{array}$ & $\begin{array}{l}8(21,1) \\
18(47,4)\end{array}$ & $\begin{array}{l}6(18,8) \\
20(62,5) \\
6(18,8)\end{array}$ & 0,389 \\
\hline $\begin{array}{l}\text { Receptores } \\
\text { Her2+, n (\%) } \\
\begin{array}{l}\text { Rec estrogénico +, } \\
\text { n (\%) }\end{array}\end{array}$ & $11(28,9)$ & $8(25)$ & 0,711 \\
$\begin{array}{l}\text { Rec progesterona +, } \\
\text { n (\%) }\end{array}$ & $36(94,7)$ & $29(90,6)$ & 0,506 \\
\hline $\begin{array}{l}\text { Ganglio positivo, n (\%) } \\
\text { (1) }(26,3)\end{array}$ & $11(34,4)$ & 0,985 \\
\hline
\end{tabular}

Los valores son expresados en número (porcentaje) o como mediana y rango intercuartílico. El valor de probabilidad, $p \leq 0.05$, era considerado como significativo. 


\subsection{ACTIVIDAD ENZIMÁTICA IDO}

Durante las primeras 6 horas de la evolución de la cirugía oncológica de mama, la actividad de la enzima IDO, medida como concentración de quinurenina en sangre, desciende significativamente respecto a los valores basales en el grupo paravertebral no llegando a recuperarlos. No se observaron diferencias entre las pacientes que recibieron analgesia paravertebral y aquellas que no lo hicieron (figura 14). La Tabla XI refleja los niveles sanguíneos de actividad de la enzima Indoleamin-2,3-Dioxigenasa encontrados en ambos grupos de pacientes.

Tabla XI. Valores medios de quinurenina medidos en micromol/L

\begin{tabular}{|l|l|l|l|}
\hline Características & Morfina $(\mathrm{n}=38)$ & Paravertebral $(\mathrm{n}=32)$ & Valor $\boldsymbol{p}$ \\
\hline Quinurenina preop & $1,94 \pm 0,57$ & $2,06 \pm 0,78$ & 0,473 \\
\hline Quinurenina intraop & $1,79 \pm 0,59$ & $1,55 \pm 0,69$ & 0,123 \\
\hline $\begin{array}{l}\text { Quinurenina postop } \\
30 \text { min }\end{array}$ & $1,85 \pm 0,7$ & $1,73 \pm 0,75$ & 0,474 \\
\hline $\begin{array}{l}\text { Quinurenina postop } \\
6 h\end{array}$ & $1,73 \pm 0,59$ & $1,59 \pm 0,65$ & 0,36 \\
\hline
\end{tabular}

Los valores son expresados como media \pm desviación típica. El valor de probabilidad, $p \leq 0.05$, era considerado como significativo. 
Figura 14. Comparación de valores de quinurenina en sangre entre el grupo de analgesia con morfina (color azul) y el grupo de analgesia paravertebral (color verde) en los diferentes tiempos de muestreo (preoperatorio, intraoperatorio, postoperatorio a los 30 minutos, postoperatorio a las 6 horas). No se detectaron diferencias estadísticamente significativas entre ambos grupos en los momentos estudiados. Sí hubo diferencias entre los valores preoperatorios y el resto de valores dentro del grupo paravertebral.

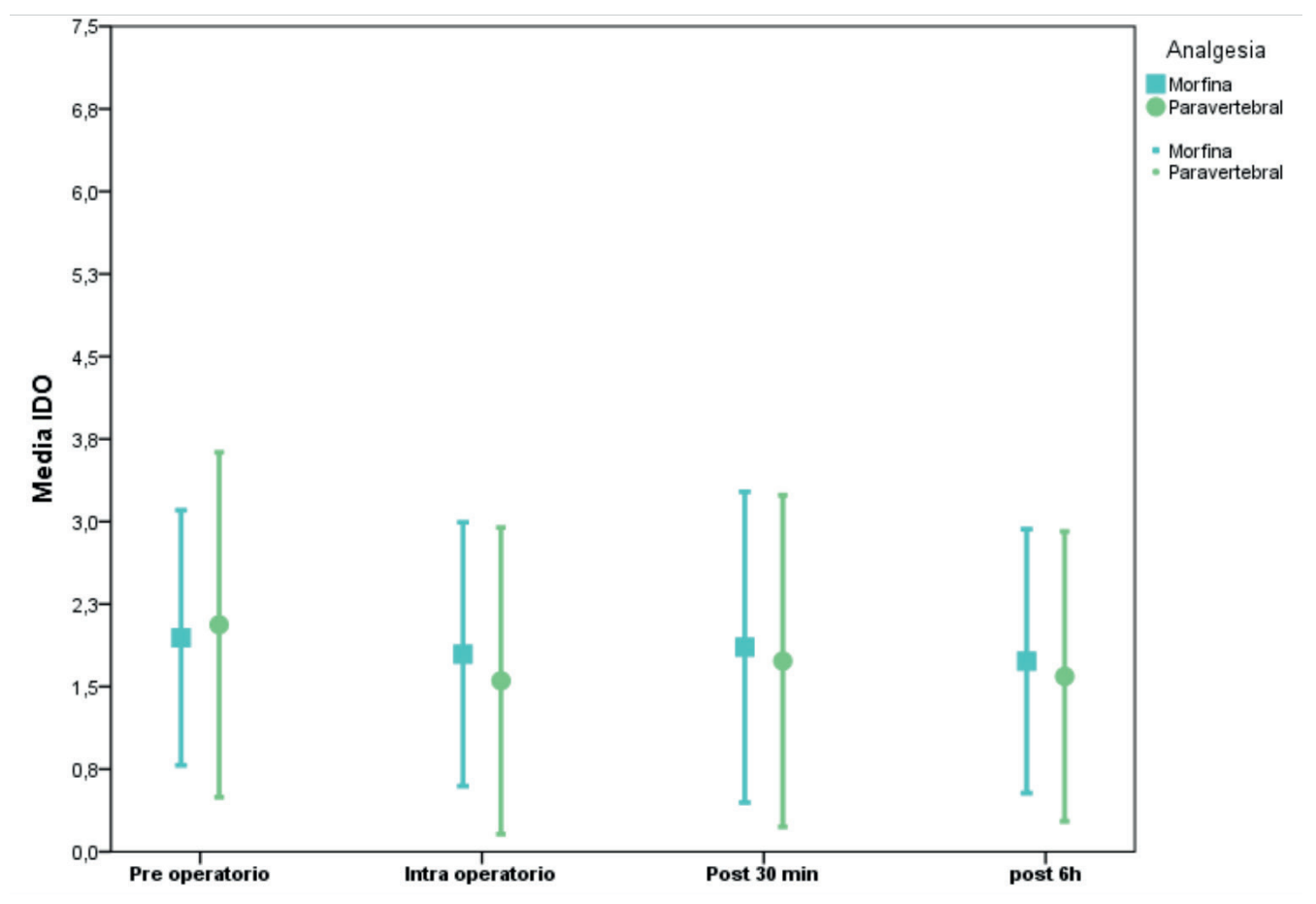




\subsection{RATIO NEUTRÓFILOS / LINFOCITOS (NLR)}

Al comparar el valor de la ratio Neutrófilos/Linfocitos postoperatoria con el valor preoperatorio se obtuvieron diferencias significativas dentro de ambos grupos de estudio, además, aunque no había diferencias entre el valor del ratio preoperatorio entre ambos grupos, sí se obtuvieron diferencias significativas entre ambos en cuanto al valor del ratio Neutrófilos/Linfocitos postoperatorio. 
Tabla XII. Comparación fórmula leucocitaria entre grupos

\begin{tabular}{|c|c|c|c|}
\hline Características & Morfina $(n=38)$ & Paravertebral $(n=32)$ & Valor $p$ \\
\hline $\begin{array}{l}\text { Leucocitos preoperat, } \\
10^{3} / \mu \mathrm{l}\end{array}$ & $6,77 \pm 1,64$ & $6,13 \pm 1,70$ & 0,115 \\
\hline $\begin{array}{l}\text { Leucocitos postope- } \\
\text { rat, } 10^{3} / \mu \mathrm{l}\end{array}$ & $7,74 \pm 2,1$ & $7,2 \pm 1,99$ & 0,28 \\
\hline $\begin{array}{l}\text { Neutrófilos preoperat, } \\
10^{3} / \mu \mathrm{l}\end{array}$ & $4,03 \pm 1,53$ & $3,52 \pm 1,42$ & 0,16 \\
\hline $\begin{array}{l}\text { Neutrófilos postope- } \\
\text { rat, } 10^{3} / \mu \mathrm{l}\end{array}$ & $5,37 \pm 1,95$ & $5,1 \pm 1,73$ & 0,556 \\
\hline $\begin{array}{l}\text { Linfocitos preoperat, } \\
10^{3} / \mu \mathrm{l}\end{array}$ & $2,2 \pm 0,55$ & $2,07 \pm 0,54$ & 0,321 \\
\hline $\begin{array}{l}\text { Linfocitos postoperat, } \\
10^{3} / \mu \mathrm{l}\end{array}$ & $1,83 \pm 0,48$ & $1,59 \pm 0,5$ & 0,051 \\
\hline $\begin{array}{l}\text { Monocitos preoperat, } \\
10^{3} / \mu \mathrm{l}\end{array}$ & $0,31(0,28-0,39)$ & $0,3(0,29-0,4)$ & 0,995 \\
\hline $\begin{array}{l}\text { Monocitos postoperat, } \\
10^{3} / \mu \mathrm{l}\end{array}$ & $0,4(0,31-0,41)$ & $0,4(0,3-0,46)$ & 0,626 \\
\hline $\begin{array}{l}\text { Eosinófilos preoperat, } \\
10^{3} / \mu \mathrm{l}\end{array}$ & $0,15 \pm 0,09$ & $0,15 \pm 0,091$ & 0,767 \\
\hline $\begin{array}{l}\text { Eosinófilos postope- } \\
\text { rat, } 10^{3} / \mu \mathrm{l}\end{array}$ & $0,09 \pm 0,06$ & $0,09 \pm 0,09$ & 0,858 \\
\hline $\begin{array}{l}\text { Basófilos preoperat, } \\
10^{3} / \mu \mathrm{l}\end{array}$ & $0,04(0,03-0,06)$ & $0,03(0,02-0,06)$ & 0,292 \\
\hline $\begin{array}{l}\text { Basófilos postoperat, } \\
10^{3} / \mu \mathrm{l}\end{array}$ & $0,02(0,01-0,03)$ & $0,02(0,01-0,03)$ & 0,634 \\
\hline $\begin{array}{l}\text { Plaquetas preoperat, } \\
10^{3} / \mu \mathrm{l}\end{array}$ & $255,53 \pm 68,98$ & $230,37 \pm 49,93$ & 0,09 \\
\hline $\begin{array}{l}\text { Plaquetas postoperat, } \\
10^{3} / \mu \mathrm{l}\end{array}$ & $212,05 \pm 68,3$ & $185,31 \pm 47,73$ & 0,067 \\
\hline
\end{tabular}

Los valores son expresados como media \pm DS o mediana y rango intercuartílico. El valor de probabilidad, $p \leq 0.05$, era considerado como significativo. 
Tabla XIII. Comparación ratios derivados de fórmula leucocitaria entre los grupos

\begin{tabular}{|l|l|l|l|}
\hline Características & Morfina $(\mathbf{n = 3 8})$ & Paravertebral $(\mathbf{n = 3 2})$ & Valor $\boldsymbol{p}$ \\
\hline $\begin{array}{l}\text { Neutrófilos/Linfocitos } \\
\text { preoperatorio }\end{array}$ & $1,84(1,29-2,43)$ & $1,8(1,3-1,94)$ & 0,409 \\
\hline $\begin{array}{l}\text { Neutrófilos/Linfocitos } \\
\text { Postoperatorio }\end{array}$ & $2,75(2,19-3,53)$ & $3,48(2,65-3,98)$ & $0,03 *$ \\
\hline Linfoc/Monocit preop, & $6,64(5,65-8,01)$ & $6,86(5,08-8,22)$ & 0,732 \\
\hline $\begin{array}{l}\text { Linfoc/Monocit posto- } \\
\text { perat, }\end{array}$ & $4,71(3,79-5,41)$ & $4,11(3,31-4,96)$ & 0,161 \\
\hline $\begin{array}{l}\text { Plaquetas/Linfoc } \\
\text { preoperat, }\end{array}$ & $\begin{array}{l}109,78(90,59- \\
141,28)\end{array}$ & $\begin{array}{l}116,7(82,63- \\
133,45)\end{array}$ & 0,953 \\
\hline $\begin{array}{l}\text { Plaquetas/Linfoc } \\
\text { postoperat, }\end{array}$ & $\begin{array}{l}111,51(94,67- \\
139,55)\end{array}$ & $\begin{array}{l}116,6(97,61- \\
153,51)\end{array}$ & 0,487 \\
\hline
\end{tabular}

Los valores son expresados como media \pm DS o mediana y rango intercuartílico. El valor de probabilidad, $p \leq 0.05$, era considerado como significativo.

Ninguna de las pacientes requirió transfusión perioperatoria de sangre. Una de las pacientes presentó un síndrome de Claude-Bernard-Horner con ptosis palpebral y miosis en el lado homolateral al bloqueo. En una paciente se produjo una colocación intrapleural del catéter detectado mediante radiografía de tórax, sin mayores consecuencias como neumotórax. Todas las pacientes fueron extubadas sin complicaciones en quirófano y trasladadas a la Unidad de Reanimación tras la intervención quirúrgica para vigilancia postoperatoria. 
NIVELES PERIOPERATORIOS DE QUINURENINA: EFECTOS DE LA ANESTESIA GENERAL VS REGIONAL 
NIVELES PERIOPERATORIOS DE QUINURENINA: EFECTOS DE LA ANESTESIA GENERAL VS REGIONAL

7. DISCUSIÓN 
NIVELES PERIOPERATORIOS DE QUINURENINA: EFECTOS DE LA ANESTESIA GENERAL VS REGIONAL 
Los hallazgos más notables de este trabajo son:

Durante la intervención quirúrgica de cáncer de mama unilateral y hasta las 6 horas postoperatorias la concentración de quinurenina descendió en ambos grupos de tratamiento analgésico, aunque sólo se obtuvieron diferencias con respecto a los valores preoperatorios en el grupo paravertebral.

No se observaron diferencias significativas entre los niveles de quinurenina sanguínea entre los dos grupos de tratamiento analgésico en ninguno de los momentos estudiados.

La ratio Neutrófilos/Linfocitos (NLR) se elevó en el postoperatorio en todas las pacientes estudiadas.

La ratio Neutrófilos/Linfocitos (NLR) fue significativamente más alta en el postoperatorio de las pacientes con analgesia paravertebral que en aquellas que recibieron opioide.

El consumo total de opioides se redujo de forma significativa en el grupo con bloqueo paravertebral.

\subsection{DATOS CLINICOS Y DEMOGRÁFICOS DE LAS PACIENTES}

Las características de nuestra muestra de pacientes en edad fueron similares a las de la población de pacientes que presentan cáncer de mama, según datos de la Sociedad Española de Oncología Médica [10]. Son pacientes de sexo femenino con una mediana de edad de 59 años, que presentan comorbilidades como hipotiroidismo, dislipemia, diabetes mellitus o hipertensión arterial, de manera similar a la epidemiología del cáncer de mama. Aunque este tipo tumoral aparece en pacientes con mayores comorbilidades, no se aceptaron en el estudio con el fin de reducir los factores de confusión que pudieran estar asociados a las mismas. Teniendo toda la población riesgo potencial de desarrollar cáncer de mama, existen determinados factores que aminoran el riesgo como ser varón, ser mayor de 75 años, carecer de genes BRCA, menopausia antes de los 55 años mientras otros aumentan la probabilidad de padecerlo como ser mujer, tener entre 50 y 75 años, ser de raza blanca, tener historia familiar de riesgo de cáncer de mama, factores hormonales endógenos o padecer enfermedades benignas previas de la mama. 
La cuantificación de analgésicos opioides requeridos perioperatoriamente en pacientes bajo anestesia regional paravertebral en cirugía de mama ha sido realizada por algunos ensayos clínicos además de ser evaluada en un reciente metanálisis. A pesar de tamaños muestrales limitados (excepto en el trabajo de Wu et al con 386 pacientes, el resto con menos de 70 pacientes), los trabajos apuntan a una reducción significativa del consumo de analgésicos opioides como morfina $[244,245]$.

Nuestro trabajo confirma la reducción en el consumo de opioides en las primeras $\mathbf{2 4}$ horas del postoperatorio de cáncer de mama cuando el bloqueo paravertebral es empleado para el control intra y postoperatorio del dolor en comparación con su no utilización. Encontramos una reducción del 83,4\% frente al metanálisis que detectó un descenso del 72\% [245]. Debemos apuntar que nosotros empleamos anestesia general con halogenados en los pacientes del grupo paravertebral, de manera contraria a otros autores que emplearon propofol, con conocido efecto analgésico [261], en este mismo grupo [244], lo que pudo tener influencia en sus resultados. No obstante, otras investigaciones emplearon bloqueo paravertebral con pacientes únicamente bajo sedación, mostrando el gran efecto analgésico de esta técnica locorregional.

La reducción del consumo de opioides es un dato interesante, en cuanto podría constituir uno de los mecanismos que se pueden encontrar detrás de la mayor recurrencia tumoral observada en pacientes operadas de cáncer de mama que recibieron morfina frente a aquellas pacientes operadas que recibieron analgesia mediante técnicas locorregionales [90].

\subsection{MODIFICACIÓN PERIOPERATORIA DE MARCADORES INFLAMATORIOS}

La variación de los niveles de actividad de Indoleamin-2,3-Dioxigenasa medida en niveles de quinurenina en función de los fármacos anestésicos empleados ha sido previamente estudiada en pacientes sometidas a histerectomía total por fibromiomatosis. Marfella et al compararon de forma randomizada el efecto que tiene sobre dicha actividad el empleo de dos anestésicos volátiles, el halotano y el isoflurano, encontrando un significativo descenso de los niveles en orina tanto a las 4 como a las 24 horas desde la inducción anestésica en comparación con los valores preoperatorios. Aquellas pacientes que recibieron el anestésico halotano mantuvieron el descenso hasta las 72 horas mientras el grupo isoflurano lo hizo sólo durante $\mathbf{4 8}$ horas. Es el primer estudio que mostró que según el tipo de anestesia empleada se podían modificar los niveles de quinurenina [213].

Recientes hipótesis basadas en el trabajo retrospectivo de Exadaktylos et al [90], que obtuvieron una supervivencia más alta en pacientes sometidas a cirugía ma- 
maria bajo analgesia paravertebral, proponen que las técnicas locorregionales pueden reducir la aparición de metástasis y/o recurrencia cuando son empleadas durante la cirugía de extirpación tumoral, como consecuencia de un bloqueo más efectivo de la respuesta inflamatoria. Nuestro estudio no apoya este planteamiento, ya que,aunque no se pudo documentar la existencia de diferencias significativas en el grupo de analgesia paravertebral con respecto al grupo con morfina ni en la medición intraoperatorio ni en el postoperatorio. A pesar de estos resultados, encontramos una reducción significativa de los valores de quinurenina respecto a los valores preoperatorios solo en el grupo de tratamiento con bloqueo paravertebral, desde la medición intraoperatoria hasta las 6 horas postoperatorias.

Durante la práctica de cualquier intervención quirúrgica, en condiciones fisiológicas, se produce una activación de la inflamación con un aumento de neutrófilos y un descenso de linfocitos, elevándose el ratio Neutrófilos/Linfocitos [247]. En caso de cirugía oncológica, esta situación supone una alteración del sistema inmune antitumoral coexistente con la presencia documentada de micrometástasis antes de iniciar la cirugía [20], además de con la liberación de células tumorales por la propia manipulación quirúrgica $[16,17]$ viéndose abocada a una biología tumoral más agresiva, progresión tumoral y empeoramiento del pronóstico oncológico [235], más aún si la respuesta inflamatoria se prolonga en el tiempo, puesto que la formación de metástasis clínicamente relevantes a partir de estas células depende del equilibrio entre el sistema inmune antitumoral y la capacidad intrínseca del tumor de sobrevivir y metastatizar [20].

Debido a estas desfavorables consecuencias, la utililzación de estrategias capaces de amortiguar la respuesta inflamatoria, sobre todo en los mencionados momentos cruciales como la intervención quirúrgica, puede resultar crítica para una menor aparición de recurrencia o metástasis como se ha documentado en investigaciones en animales y humanos [20]. Durante el perioperatorio, la modificación de los niveles de subpoblaciones leucocitarias asociada al empleo de técnicas anestésicas locorregionales durante la cirugía ha sido repetidamente investigada en múltiples tipos de cirugía. A pesar de que aumentó el número de neutrófilos y se redujo el de linfocitos respecto a los valores preoperatorios, los trabajos no observaron diferencias significativas entre los grupos de analgesia epidural y analgesia opioide [239-243], tampoco cuando se emplearon en cirugía infantil [242]. De entre toda la literatura publicada, únicamente Rem y colaboradores objetivaron que, en histerectomía abdominal, la anestesia epidural prevenía la aparición de la linfopenia y granulocitosis postoperatorias inducidas por la anestesia general, indicando que la inhibición de la respuesta endocrino-metabólica a la cirugía también previene la inmunosupresión postoperatoria [240].

Nuestro trabajo corrobora los datos de estudios previos en cuanto al ascenso de neutrófilos y descenso de linfocitos en el postoperatorio, pero no fue capz de encontrar diferencias significativas entre los grupos de estudio. 
Los valores absolutos de neutrófilos y linfocitos están relacionados con la biología oncológica pero se pueden ver afectados en su función como marcadores inflamatorios y pronósticos por múltiples factores fisiológicos, patológicos y físicos, mientras que la ratio Neutrófilos/Linfocitos, obtenida al dividir el número de neutrófilos entre el número de linfocitos, se caracteriza por poseer una estabilidad superior, pudiendo además ser determinada de forma fácil y barata en plasma o suero, y aplicada precoz y ampliamente en clínica [221-231]. Esta ratio ha sido asociada a la gravedad y estadio de la enfermedad oncológica y, recientemente, la evidencia sobre el papel predictivo de la misma en diferentes procesos inflamatorios como eventos cardiovasculares, sepsis, además de en la respuesta al tratamiento oncológico tanto quirúrgico como quimioterápico ha aumentado [256-258]. Como consecuencia de la heterogenicidad de los valores de la ratio tomados como referencia en los distintos trabajos en los que se ha valorado su capacidad predicitiva, algunos autores han propuesto, que debe ser tenido en cuenta el cambio ascendente o descendente del mismo, más que el valor en sí mismo $[53,260]$.

Tomando en consideración que continúan siendo desconocidos los mecanismos exactos por los que la anestesia regional parece reducir la mortalidad postoperatoria oncológica por recurrencia o metástasis, es plausible que pueda deberse a un descenso del valor de la ratio Neutrófilos/Linfocitos entre el inicio y el fin del tratamiento quirúrgico. El primer trabajo que describía cómo varia este valor en relación con el empleo de distintas técnicas anestésicas ha sido publicado en el último año, donde los autores examinaron si la técnica anestésica (intravenosa versus inhalatoria) podía afectar a la ratio Neutrófilos/Linfocitos durante la cirugía de histerectomía laparoscópica por patología benigna. A pesar de ser una cirugía poco agresiva y de limitada respuesta inflamatoria, los autores lograron encontrar diferencias estadísticamente significativas en los valores a las 2 horas de la cirugía siendo más bajo en el grupo de anestesia total intravenosa (TIVA) frente al de sevoflurano $(7,87 \pm 2,8$ frente a $10,24 \pm 3,35, p=0,02$ ) [53]. A diferencia de nuestro trabajo, no hallaron diferencias significativas entre los grupos a las 24 horas de la cirugía, único momento en el que hicimos la medición postoperatoria del ratio, y donde encontramos diferencias en comparación con el valor preoperatorio en ambos grupos y, además, entre los grupos, estando el valor significativamente más elevado en el grupo paravertebral. Una explicación a las discrepacias con el estudio previo podría ser que las pacientes se intervinieron laparoscópicamente y, por tanto, con menor agresividad, lo que podría haber contribuido a retomar a los valores del preoperatorio de forma más precoz. A partir de sus resultados dichos autores llegaron a la conclusión de que modificando el tipo de anestesia se podía cambiar la alteración del ratio Neutrófilos/Linfocitos ocasionada por el acto quirúrgico.

Choi et al a su vez hicieron una valoración de la repercusión de la analgesia multimodal con empleo de AINEs sobre la ratio Neutrófilos/Linfocitos, recogiendo los 
datos retrospectivamente, en pacientes con cáncer de pulmón que iban a ser intervenidos quirúrgicamente. Aunque el valor de la ratio postoperatoria fue menor en los pacientes que recibieron AINEs comparado con los que no los recibieron, la diferencia no fue estadísticamente significativa $(9,98 \pm 6,64$ versus $10,58 \pm 6,82, p=0,06)$. Además, se analizó el efecto de su valor sobre la supervivencia, detectando que el valor del ratio Neutrófilos/Linfocitos de manera preoperatoria estaba directamente relacionado con la supervivencia de los pacientes, no encontrándose esta relación con el valor postoperatorio [229].

Previamente a estas publicaciones, varios autores examinaron el efecto sinérgico del empleo de combinaciones de técnicas de anestesia (por ejemplo, anestesia regional junto a propofol intravenoso para el mantenimiento anestésico) durante la cirugía oncológica, debido a que su empleo por separado mostraba propiedades beneficiosas sobre el sistema inmune, observando que aquellas pacientes operadas bajo esta combinación anestésica regional/propofol veían reducidas significativamente las citoquinas proinflamatorias circulantes [48] así como la concentración de factores de crecimiento como VEGF ( 733 verus $27 \mathrm{pg} / \mathrm{ml}, \mathrm{p}=0,001$ ) [49], que se sabe están implicados en el crecimiento tumoral. Deegan y cols. observaron el comportamiento in vitro de células de cáncer mamario a las que se les añadía suero extraido de pacientes anestesiadas con dicha combinación bloqueo paravertebral/propofol o bien con sevoflurano/morfina, detectando que presentaban significativamente mayor proliferación aquellas células tumorales que recibieron el suero de pacientes anestesiadas con sevoflurano y opioide $(-24 \%$ versus $73 \%, p=0,01)$, no encontrando diferencias en cuanto a la migración [131]. Otros autores mostraron que dicho primer suero también reducía la apoptosis de células tumorales de mama [238]. Con estos resultados, siendo aún desconocidos los mecanismos exactos, el empleo combinado de técnicas anestésicas parece tener mayor repercusión sobre ciertos parámetros inflamatorios y protumorales que el empleo aislado de técnicas regionales. A pesar de estas observaciones, se desconoce por el momento el impacto real sobre la supervivencia de esta combinación, aunque se están llevando a cabo estudios prospectivos de gran tamaño muestral con el objetivo de esclarecerlo [20].

Nuestro trabajo encontró que la anestesia regional en pacientes sometidas a cirugía oncológica de mama aumenta la ratio Neutrófilos/Linfocitos, de manera que no apoya una reducción de la inflamación intraoperatoria asociada al uso de este bloqueo nervioso. Una posible explicación a este resultado es que la técnica paravertebral fuese suficiente para controlar el dolor pero no para reducir la inflamación asociada. A diferencia de las publicaciones mencionadas, debemos destacar que en nuestro estudio el empleo de anestesia regional fue suficiente para arrojar resultados estadísticamente significativos. Cabe preguntarse si habrían obtenido dicha significación sin usar propofol y si nosotros habríamos obtenido mayores diferencias en los resultados, en caso de haberlo asociado en el grupo de bloqueo paravertebral. 
Desconocemos cuál es el papel que tienen estos resultados sobre la supervivencia, siendo importante señalar que las pacientes continúan en seguimiento para conocer su estadística de supervivencia con el objetivo de aportar conclusiones más sólidas sobre los datos presentados. Debemos ser cautelosos pues todavía existen datos contradictorios y la consistencia y magnitud del impacto pronóstico de la ratio Neutrófilos/Linfocitos permanece sin estar clara [221,225], apoyada esta afirmación por los datos de algunos metanálisis realizados, y sin encontrar beneficio alguno en recurrencia o supervivencia con el empleo de técnicas locorregionales algunos estudios $[91,120]$. El periodo perioperatorio continúa presentándose como una ventana de oportunidad puesto que se ha mostrado desproporcionadamente crucial, teniendo en cuenta su breve duración respecto a la del tratamiento oncológico completo, a la hora de determinar la recurrencia oncológica a largo plazo encontrándose todavía prácticamente inexplorado, y con resultados controvertidos, del que se espera explotar su máximo potencial de cara a obtener los mejores resultados del tratamiento tumoral actualmente disponible.

\subsection{LIMITACIONES DEL ESTUDIO}

Se describen a continuación las limitaciones principales de esta investigación:

Consideramos que la inclusión de un mayor número de pacientes dado el pequeño tamaño de nuestra muestra podría haber contribuido a la obtención de mayor número de diferencias significativas, resultados.

Existe una falta de evaluación de datos más tardíos acerca de la actividad de IDO, como a las 24 o 48 horas de la intervención quirúrgica, donde otros estudios han encontrado un regreso a los niveles normales de los metabolitos del triptófano.

La existencia de un grupo control con pacientes sometidas a cirugía no oncológica hubiese permitido comparar la evolución de los niveles de quinuurenina y de ratio Neutrófilos/Linfocitos en sujetos sin enfermedad maligna.

Debido a que la magnitud de los cambios inflamatorios es proporcional a la extensión del trauma quirúrgico, la elección de una cirugía menor para la evaluación de parámetros inflamatorios puede haber influido en no ser capaz de mostrar una mayor diferencia en las alteraciones de los mismos entre los grupos. 
La realización de la investigación en un solo centro hospitalario puede haber influido en los resultados observados.

Es posible que existan factores de confusión que escapan al control de los investigadores en este estudio y que podrían haber influenciado los resultados, como la hipotermia perioperatoria inadvertida y otros factores influyentes en la actividad IDO y en la ratio Neutrófilos/Linfocitos aún desconocidos.

\subsection{APLICACIÓN DE NUESTROS RESULTADOS A LA PRÁCTICA CLÍNICA}

Nuestro trabajo muestra que la activación de la enzima de inmunotolerancia indoleamin-2,3-dioxigenasa medida como niveles sanguíneos de quinurenina no es diferente durante cirugía oncológica mamaria al emplear diferentes métodos de analgesia como la regional o la opioide con morfina.

Basados en estos resultados no se puede apoyar categóricamente un cambio en las actuaciones clínicas habituales respecto a la analgesia paravertebral en pacientes oncológicas de mama considerando únicamente criterios de inmunomodulación perioperatoria. Siendo completamente estrictos con los resultados obtenidos con el presente trabajo, debería incluso evitarse la analgesia paravertebral en cirugía oncológica mamaria, al haberse observado un aumento postoperatorio del valor del Ratio Neutrófilos/Linfocitos, con función predictora pronóstica.

La decisión de emplear analgesia regional paravertebral en cirugía oncológica mamaria, debería basarse en otros criterios, como por ejemplo la reducción en la necesidad de anestésicos generales pudiendo emplearse como técnica anestésica única [157], o la reducción de la prevalencia de dolor crónico en la zona intervenida [159].

Nuestros resultados también objetivaron que la analgesia regional mediante bloqueo paravertebral reduce el consumo de analgésicos opioides de manera significativa, pudiendo emplearse con este objetivo en aquellas pacientes en los que estuvieran contraindicados los opioides o que quisieramos reducir su uso. 


\subsection{FUTUROS ESTUDIOS}

Podría ser de interés conocer el tiempo que tarda en normalizarse el nivel de quinurenina y la ratio Neutrófilos/Linfocitos y observar si las diferencias documentadas entre los grupos de analgesia se mantienen de forma más prolongada. Esto requeriría realizar una investigación aumentando los días de seguimiento de las pacientes hasta la vuelta a los niveles basales de quinurenina y ratio Neutrófilos/Linfocitos.

Otro aspecto de importancia sería demostrar si las diferencias en los niveles de quinurenina y ratio Neutrófilos/Linfocitos observadas entre ambos grupos de tratamiento analgésico, aun siendo significativas, son lo suficientemente importantes para poder modificar el comportamiento de las células tumorales in vitro o en un modelo experimental y tener repercusión sobre la supervivencia de las pacientes.

Futuras investigaciones podrían comparar el empleo de técnicas anestésicas combinadas con el empleo de propofol, fármaco que ha demostrado aumentar la apoptosis de células tumorales frente a técnicas convencionales con agentes inhalatorios y morfina en su impacto sobre ratios sencillos como la ratio Neutrófilos/Linfocitos o de obtención algo más compleja como la quinurenina.

Nuevas trabajos deberían profundizar en la búsqueda de otros posibles mecanismos implicados en la mejora de la supervivencia observada en diferentes investigaciones cuando se empleó la anestesia locorregional.

Se debe insistir en explorar otras variables perioperatorias que puedan estar en relación con variaciones en el pronóstico oncológico de manera que pueda explotarse en todo su potencial este corto, pero crítico periodo en la evolución tumoral. 
NIVELES PERIOPERATORIOS DE QUINURENINA: EFECTOS DE LA ANESTESIA GENERAL VS REGIONAL 
NIVELES PERIOPERATORIOS DE QUINURENINA: EFECTOS DE LA ANESTESIA GENERAL VS REGIONAL 
Los niveles intraoperatorios y postoperatorios de quinurenina se redujeron significativamente respecto a los niveles del preoperatorio cuando las pacientes fueron analgesiadas mediante bloqueo paravertebral en cirugía oncológica mamaria unilateral. En este grupo, los niveles no volvieron a los valores preoperatorios durante el periodo analizado.

Las pacientes que recibieron morfina no presentaron cambios significativos en los niveles de quinurenina sanguínea. No se observaron diferencias significativas con el grupo de analgesia paravertebral.

Ambos grupos de tratamiento analgésico presentaron un aumento postoperatorio de la ratio Neutrófilos/Linfocitos, siendo significativamente mayor en el grupo que recibió técnicas locorregionales comparado con con aquellas que percibieron analgesia opioide en cirugía unilateral de cáncer de mama.

Las pacientes que recibieron analgesia locorregional redujeron de forma significativa el consumo de opioides tanto intraoperatoriamente como en el postoperatorio.

En consecuencia consideramos que debe estudiarse más en profundidad cuál es el papel de la anestesia locorregional, y más concretamente, la anestesia paravertebral en los procesos inflamatorios perioperatorios y sus efectos a largo plazo antes de hacer recomendaciones sobre el manejo anestésico perioperatorio en cirugía oncológica. 
NIVELES PERIOPERATORIOS DE QUINURENINA: EFECTOS DE LA ANESTESIA GENERAL VS REGIONAL 
NIVELES PERIOPERATORIOS DE QUINURENINA: EFECTOS DE LA ANESTESIA GENERAL VS REGIONAL

9. BIBLIOGRAFÍA 
NIVELES PERIOPERATORIOS DE QUINURENINA: EFECTOS DE LA ANESTESIA GENERAL VS REGIONAL 
1. Varios autores. Historia de la Oncología Médica en España. 2009. Sociedad Española de Oncología Médica.

2. Lizón J. Evolución de la Oncología Médica desde sus inicios. Marco actual. Primer libro blanco de la Oncología Médica en España. 1995. Varios autores. Federación de Sociedades Españolas de Oncología.

3. Hadzic A. Historia de la anestesia local. En: Deschner B, Robards C, Somasundaram L, Harrop-Griffiths W. Tratado de anestesia regional y manejo del dolor agudo. Nueva York: McGraw Hill Medical; p 3-18.

4. Raj P. Tratado de Dolor. Mosby; 2000.

5. Bonica J. Manejo del Dolor. Lea y Febiger; 1953.

6. Riera Palmero J. Breve historia de la anestesiología. Volumen 48 de Acta Histórico-Médica vallisoletana: Monografías. Universidad de Valladolid. 1997.

7. American Cancer Society. Cancer Facts and Figures 2012. Available from http://www.cancer.org/research/cancerfactsfigures/ cancer-facts-figures-2012. Atlanta: American Cancer Society, 2012.

8. Cancer Research UK. CancerStats: Cancer Stats for the UK. Available from http://www.cancerresearchuk.org/cancer-info/ cancerstats/incidence (accessed 30 August 2012) Jemal A, Siegel R, Xu J, Ward E. Cancer statistics, 2010. CA Cancer J Clin 2010; 60: 277-300.

9. Cancer Statistics, UK. Available from http://info.cancerresearchuk.org/cancerstats/incidence/.2011. RefType: InternetCommunication.

10. www.seom.org. Web de la Sociedad Española de Oncología Médica. http:// www.seom.org/es/informacion-sobre-el-cancer/info-tipos-cancer/cancer-de-mama-raiz/cancer-de-mama?start=2\#content.

11. Baum M, Demicheli R, Hrushesky W, Retsky M. Does surgery unfavourably perturb the 'natural history' of early breast cancer by accelerating the appearance of distant metastases? Eur J Cancer 2005; 41(4): 508-15.

12. Demicheli $R$, Valagussa $P$, Bonadonna $G$. Does surgery modify growth kinetics of breast cancer micrometastases? Br J Cancer. 2001; 85(4): 490-492. 
13. Thaker PH, Han LY, Kamat AA, Arevalo JM, Takahashi R, Lu C et al. Chronic stress promotes tumor growth and angiogenesis in a mouse model of ovarian carcinoma. Nat Med. 2006; 12(8): 939-944.

14. Inbar S, Neeman E, Avraham R, Benish M, Rosenne E, Ben-Eliyahu S. Do stress responses promote leukemia progression? An animal study suggesting a role for epinephrine and prostaglandin-E2 through reduced NK activity. PLoS One. 2011; 6(4): e19246.

15. Weckermann D, Polzer B, Ragg T, Blana A, Schlimok G, Arnholdt H et al. Perioperative activation of disseminated tumor cells in bone marrow of patients with prostate cancer. J Clin Oncol. 2009; 27(10): 1549-56.

16. Galan M, Vinolas N, Colomer D, Soler G, Muñoz M, Longarón R et al. Detection of occult breast cancer cells by amplification of CK19 mRNA by reverse transcriptaseYpolymerase chain reaction: role of surgical manipulation. Anticancer Res. 2002; 22(5): 2877-2884.

17. Eschwege $P$, Dumas F, Blanchet $P$, Le Maire V, Benoit G, Jardin A et al. Haematogenous dissemination of prostatic epithelial cells during radical prostatectomy. Lancet. 1995; 346(8989): 1528-1530.

18. Yamashita J, Matsuo A, Kurusu Y, Saishoji T, Hayashi N, Ogawa M. Preoperative evidence of circulating tumor cells by means of reverse transcriptase-polymerase chain reaction for carcinoembryonic antigen messenger RNA is an independent predictor of survival in non-small cell lung cancer: a prospective study. J Thorac Cardiovasc Surg. 2002; 124(2): 299-305.

19. Peach G, Kim C, Zacharakis E, Purkayastha S, Ziprin P. Prognostic significance of circulating tumour cells following surgical resection of colorectal cancers: $a$ systematic review. Br J Cancer. 2010; 102(9): 1327-1334.

20. Sessler DI, Ben-Eliyahu S, Mascha EJ, Parat MO, Buggy DJ. Can regional analgesia reduce the risk of recurrence after breast cancer? Methodology of a multicenter randomized trial. Contemp Clin Trials. 2008;29(4): 517-526. borrar 53

21. Antoni MH, Lutgendorf SK, Cole SW, Dhabhar FS, Sephton SE, McDonald PG et al. The influence of biobehavioural factors on tumour biology: pathways and mechanisms. Nat Rev Cancer. 2006; 6(3): 240-8.

22. Penn I. The effect of immunosuppression on pre-existing cancers. Transplantation. 1993; 55(4): 742-747. 
23. Torres L. Tratado de Anestesia y Reanimación. Ed Aran. 2001.

24. Fidler IJ. The pathogenesis of cancer metastasis: the seed and soil hypothesis revisited. Nat Rev 2003; 3: 453-8 8 Hanahan D, Weinberg RA. The hallmarks of cancer. Cell 2000; 100: 57-70.

25. Langley RR, Fidler IJ. The seed and soil hypothesis revisited - the role of tumor-stroma interactions in metastasis to different organs. Int J Cancer. 2011; 128(11): 2527-35.

26. Purtilo DT. Defective immune surveillance in viral carcinogenesis. Lab Invest. 1984; 51(4): 373-85.

27. Mosmann TR, Coffman RL. Th 1 and Th 2 cells: Different patterns of lymphokine secretion lead to different functional properties. Ann Rev Immunol. 1989; 7: 145-173.

28. Ben-Eliyahu S, Page GG, Yirmiya R, Shakhar G. Evidence that stress and surgical interventions promote tumor development by suppressing natural killer cell activity. Int J Cancer. 1999; 80(6): 880-8.

29. Kehlet $H$. The stress response to surgery. In: Cousins $M$, Brinderbough $M$, editors. Neural blockade in anaesthesia and pain management. New York: Lippincott-Williams; 1998.

30. Sood AK, Bhatty R, Kamat AA, Landen CN, Han L, Thaker PH et al. Stress hormone-mediated invasion of ovarian cancer cells. Clin Cancer Res. 2006; 12(2): 369-75.

31. Boomsma MF, Garssen B, Slot E, Berbee M, Berkhof J, Meezenbroek Ede J et al. Breast cancer surgery-induced immunomodulation. J Surg Oncol. 2010; 102(6): 640-8.

32. Hussain SP, Harris CC. Inflammation and cancer: an ancient link with novel potentials. Int J Cancer. 2007; 121(11): 2373-2380.

33. Kube P, Mroczkowski P, Granowski D, Bendedix F, Sahm M et al; Study group Qualitätssicherung Kolon/Rektum-Karzinome (Primärtumor) (Quality assurance in primary colorectal carcinoma). Anastomotic leakage after colon cancer surgery: a predictor of significant morbidity and hospital mortality, and diminished tumour-free survival. Eur J Surg Oncol. 2010; 36(2): 120 - 4. 
34. Mirnezami A, Mirnezami R, Chandrakumaran K, Sasapu K, Sagar P, Finan P. Increased local recurrence and reduced survival from colorectal cancer following anastomotic leak: systematic review and meta-analysis. Ann Surg. 2011; 253(5): 890-9.

35. Matsuda A, Matsumoto $\mathrm{S}$, Seya $\mathrm{T}$, Matsutani $\mathrm{T}$, Kishi $\mathrm{T}$, Yokoi $\mathrm{K}$ et al. Does postoperative complication have a negative impact on long-term outcomes following hepatic resection for colorectal liver metastasis?: a meta-analysis. Ann Surg Oncol. 2013; 20(8): 2485-92.

36. Allendorf JD, Bessler M, Whelan RL, Trokel M, Laird DA, Terry MB et al. Postoperative immune function varies inversely with the degree of surgical trauma in a murine model. Surg Endosc. 1997; 11(5): 427-30.

37. Engler H, Dawils L, Hoves S, Kurth S, Stevenson JR, Schauenstein K et al. Effects of social stress on blood leukocyte distribution: the role of alpha- and betaadrenergic mechanisms. J Neuroimmunol. 2004; 156(1-2): 153-62.

38. Shakhar G, Ben-Eliyahu S. In vivo beta-adrenergic stimulation suppresses natural killer activity and compromises resistance to tumor metastasis in rats. J Immunol. 1998; 160 (7): 3251-3258.

39. Neeman E, Zmora O, Ben-Eliyahu S. A new approach to reducing postsurgical cancer recurrence: Perioperative targeting of catecholamines and prostaglandins. Clin Cancer Res. 2012; 18(18): 4895-4902.

40. Elenkov IJ, Chrousos GP. Stress hormones, proinflammatory and antiinflammatory cytokines, and autoimmunity. Ann NY Acad. Sci. 2002; 966: 290-303.

41. Benish M, Ben-Eliyahu S. Surgery as a double-edged sword: A clinically feasible approach to overcome the metastasis-promoting effects of surgery by blunting stress and prostaglandin responses. Cancers. 2010; 2(4): 1929-1951.

42. Lutgendorf SK, Cole S, Costanzo E, Bradley S, Coffin J, Jabbari S et al. Stress-related mediators stimulate vascular endothelial growth factor secretion by two ovarian cancer cell lines. Clin Cancer Res. 2003; 9(12): 4514-21.

43. Sica A, Schioppa T, Mantovani A, Allavena P. Tumour-associated macrophages are a distinct M2 polarised population promoting tumour progression: potential targets of anti-cancer therapy. Eur J Cancer. 2006; 42(6): 717-727. 
44. Roche-Nagle G, Connolly EM, Eng M, Bouchier-Hayes DJ, Harmey, JH. Antimetastatic activity of a cyclooxygenase-2 inhibitor. Br J Cancer. 2004; 91(2): 359-365.

45. Soumaoro LT, Uetake H, Higuchi T, Takagi Y, Enomoto M, Sugihara K. Cyclooxygenase-2 expression: a significant prognostic indicator for patients with colorectal cancer. Clin. Cancer Res. 2004; 10 (24): 8465-8471.

46. Orozco HD, Garutti I, Moraga FJG, Sánchez-Pedrosa G. Diseminación tumoral perioperatoria. 1. Influencia de los factores perioperatorios. Rev Esp Anestesiol Reanim. 2012; 59(5): 259-266.

47. Muller-Edenborn B, Roth-Z'graggen $B$, Bartnicka K, Borgeat A, Hoos A, Borsig $L$ et al. Volatile anesthetics reduce invasion of colorectal cancer cells through down-regulation of matrix metalloproteinase-9. Anesthesiology. 2012; 117(2): 293-301.

48. Deegan CA, Murray D, Doran P, Moriarty DC, Sessler DI, Mascha E et al. Anesthetic technique and the cytokine and matrix metalloproteinase response to primary breast cancer surgery. Reg Anesth Pain Med. 2010; 35(6): 490-5. borrar 130.

49. Looney M, Doran P, Buggy DJ. Effect of anesthetic technique on serum vascular endothelial growth factor $\mathrm{C}$ and transforming growth factor beta in women undergoing anesthesia and surgery for breast cancer. Anesthesiology. 2010; 113(5): 1118-25.

50. Yamamoto $Y$, Toi M, Kondo S, Matsumoto T, Suzuki H, Kitamura M et al. Concentrations of vascular endothelial growth factor in the sera of normal controls and cancer patients. Clin Cancer Res. 1996; 2(5): 821-826.

51. Hormbrey E, Han C, Roberts A, McGrouther DA, Harris AL. The relationship of human wound vascular endothelial growth factor (VEGF) after breast cancer surgery to circulating VEGF and angiogenesis. Clin Cancer Res. 2003; 9(12): 4332 - 9.

52. O'Riain SC, Buggy DJ, Kerin MJ, Watson RW, Moriarty DC. Inhibition of the stress response to breast cancer surgery by regional anesthesia and analgesia does not affect vascular endothelial growth factor and prostaglandin E2. Anesth Analg. 2005; 100(1): 244-9. 
53. Kim WH, Jin HS, Ko JS, Hahm TS, Lee SM, Cho HS, Kim MH. The effect of anesthetic techniques on neutrophil-to-lymphocyte ratio after laparoscopy-assisted vaginal hysterectomy. Acta Anaesthesiol Taiwan. 2011; 49(3): 83-7.

54. Muñoz M, Rosso M, Casinello F, Coveñas R. Paravertebral anesthesia: how substance $P$ and the NK-1 receptor could be involved in regional block and breast cancer recurrence," Breast Cancer Res Treat. 2010; 122(2): 601-3.

55. Brand JM, Kirchner H, Poppe C, Schmucker P. The effects of general anesthesia on human peripheral immune cell distribution and cytokine production. Clin Immunol Immunopathol. 1997; 83(2): 190-4.

56. Huitink JM, Heimerikxs M, Nieuwland M, Loer SA, Brugman W, Velds A et al. Volatile anesthetics modulate gene expression in breast and brain tumor cells. Anesth Analg. 2010; 111(6): 1411-5.

57. Katzav S, Shapiro J, SegalS, Feldman M. General anesthesia during excision of a mouse tumor accelerates postsurgical growth of metastases by suppression of natural killer cell activity. Isr J Med Sci. 1986; 22(5): 339-345.

58. Melamed R, Bar-Yosef S, Shakhar G, Shakhar K, Ben-Eliyahu S. Suppression of natural killer cell activity and promotion of tumor metastasis by ketamine, thiopental, and halothane, but not by propofol: mediating mechanisms and prophylactic measures. Anesth Analg. 2003; 97(5): 1331-9.

59. Waxler B, Zhang X, Wezeman FH. Anesthetic agents modify tissue proteinase inhibitor content and tumor behaviour. J Lab Clin Med. 1994 Jan; 123(1): 53-58.

60. Kvolik S, Glavas-Obrovac L, Bares V, Karner I. Effects of inhalation anaesthetics halothane, sevoflurane, and isoflurane on human cell lines. LifeSci. 2005; 77(19): 2369-83.

61. Hashimoto H, Araki I, Sato T, Matsuki A. Clinical study on total intravenous anesthesia with droperidol, fentanyl and ketamine. Effects on natural killer cell activity. Masui. 1991; 40 (6): 912-917.

62. Kawaraguchi Y, Horikawa YT, Murphy AN, Murray F, Miyanohara A, Ali SS et al. Volatile anesthetics protect cancer cells against tumor necrosis factor-related apoptosis-inducing ligand-induced apoptosis via caveolins. Anesthesiology. 2011; 115(3): 499-508. 
63. Jun R, Gui-he Z, Xing-xing S, Hui Z, Li-xian X. Isoflurane enhances malignancy of head and neck squamous cell carcinoma cell lines: a preliminary study in vitro. Oral Oncol. 2011; 47(5): 329-33.

64. Moudgil GC, Singal DP. Halothane and isoflurane enhance melanoma tumour metastasis in mice. Can J Anaesth. 1997; 44(1): 90-94.

65. Mitsuhata H, Shimizu R, Yokoyama MM. Suppressive effects of volatile anaesthetics on cytokine release in human peripheral blood mononuclear cells. Int J Immunopharmacol. 1995; 17(6): 529-34.

66. Ke JJ, Zhan J, Feng XB, Wu Y, Rao Y, Wang YL. A comparison of the effect of total intravenous anaesthesia with propofol and remifentanil and inhalational anaesthesia with isoflurane on the release of pro- and anti-inflammatory cytokines in patients undergoing open cholecystectomy. Anaesth Intensive Care. 2008; 36(1): 74-8.

67. Ren XF, Li WZ, Meng FY, Lin CF. Differential effects of propofol and isoflurane on the activation of T-helper cells in lung cancer patients. Anaesthesia. 2010; 65(5): 478-82.

68. Hieber S, Huhn R, Hollmann MW, Weber, Preckel B. Hypoxia-inducible factor 1 and related gene products in anaesthetic-induced preconditioning. Eur J Anaesthesiol. 2009; 26(3): 201-206.

69. Ecimovic P, McHugh B, Murray D, Doran P, Buggy D. Direct effect of sevoflurane on breast cancer cell function in vitro: BAPCPC1-1. European Journal Anesthesiology. 2010; 27(47): 1.

70. Yuki K, Astrof NS, Bracken C, Soriano SG, Shimaoka M. Sevoflurane binds and allosterically blocks integrin lymphocyte function-associated antigen-1. Anesthesiology. 2010; 113(3): 600-9.

71. Liang $H$, Gu M, Yang $C$, Wang $H$, Wen $X$, Zhou Q. Sevoflurane inhibits invasion and migration of lung cancer cells by inactivating the p38 MAPK signaling pathway. J Anesth. 2012; 26(3): 381-92.

72. Kvolik S, Dobrosevic B, Marczi S, Prlic L, Glavas-Obrovac L. Different apoptosis ratios and gene expressions in two human cell lines after sevoflurane anaesthesia. Acta Anaesthesiol Scand. 2009; 53(9): 1192-9. 
73. Lindholm ML, Granath F, Eriksson LI, Sandin R. Malignant disease within $\mathbf{5}$ years after surgery in relation to duration of sevoflurane anesthesia and time with bispectral index under 45. Anesth Analg. 2011; 113(4): 778-83.

74. Mammoto T, Mukai M, Mammoto A, Yamanaka Y, Hayashi Y, Mashimo T et al. Intravenous anaesthetic, propofol inhibits invasion of cancer cells. Cancer Lett. 2002; 184(2): 165-70.

75. Tsuchiya M, Asada A, Arita K, Utsumi T, Yoshida T, Sato EF et al. Induction and mechanism of apoptotic cell death by propofol in HL-60 cells. Acta Anaesthesiol Scand. 2002; 46(9): 1068-1074.

76. Miao Y, Zhang Y, Wan H, Chen L and Wang F. GABA-receptor agonist, propofol inhibits invasion of colon carcinoma cells. Biomed Pharmacother. 2010; 64(9): 583-588.

77. Inada T, Kubo K, Shingu K. Vaccines using dendritic cells, differentiated with propofol, enhance antitumor immunity in mice. Immunopharmacol Immunotoxicol. 2009; 31(1): 150-7.

78. Brasil LJ, San-Miguel B, Kretzmann NA, Amaral JL, Zettler CG, Marroni N et al. Halothane induces oxidative stress and NF-kappaB activation in rat liver: protective effect of propofol. Toxicology. 2006; 227(1-2): 53-61.

79. Garib V, Niggemann B, Zänker KS, Brandt L, Kubens BS. Influence of non-volatile anesthetics on the migration behavior of the human breast cancer cell line MDA-MB-468. Acta Anaesthesiol Scand. 2002; 46(7): 836-844.

80. Flórez J. Farmacología humana. Ed Masson.

81. Sacerdote P, Bianchi M, Gaspani L, Manfredi B, Maucione A, Terno G et al. The effects of tramadol and morphine on immune responses and pain after surgery in cancer patients. Anesth Analg. 2000; 90(6): 1411-4.

82. Mojadadi S, Jamali A, Khansarinejad B, Soleimanjahi H, Bamdad T. Acute morphine administration reduces cell-mediated immunity and induces reactivation of latent herpes simplex virus type 1 in BALB/c mice. Cell Molecul Immunol. 2009; 6(2): 111-6.

83. Yeager MP, Colacchio TA, Yu CT, Hildebrandt L, Howell AL, Weiss J et al. Morphine inhibits spontaneous and cytokine-enhanced natural killer cell cytotoxicity 
in volunteers. Anesthesiology. 1995; 83(3): 500-8.

84. Fujioka N, Nguyen J, Chen C, Li Y, Pasrija T, Niehans G et al. Morphine-induced epidermal growth factor pathway activation in non-small cell lung cancer. Anesth Analg. 2011; 113(6): 1353-1364.

85. Lennon FE, Mirzapoiazova T, Mambetsariev B, Salgia R, Moss J, Singleton PA. Overexpression of the mu-opioid receptor in human non-small cell lung cancer promotes Akt and mTOR activation, tumor growth, and metastasis. Anesthesiology. 2012; 116(4): 857-67.

86. Ecimovic P, Murray D, Doran P, McDonald J, Lambert DG, Buggy DJ. Direct effect of morphine on breast cancer cell function in vitro: role of the NET1 gene. Br J Anaesth. 2011; 107(6): 916-23.

87. Chang PJ, Chen MY, Huang YS, Lee CH, Huang CC, Lam CF et al. Morphine enhances tissue content of collagen and increases wound tensile strength. J Anesth. 2010; 24(2): 240-6.

88. Gupta K, Kshirsagar S, Chang L, Schwartz R, Law PY, Yee D et al. Morphine stimulates angiogenesis by activating proangiogenic and survival-promoting signaling and promotes breast tumor growth. Cancer Res. 2002; 62(15): 4491-8.

89. Mathew B, Lennon FE, Siegler J, Mirzapoiazova T, Mambetsariev N, Sammani $\mathrm{S}$ et al. The novel role of the mu opioid receptor in lung cancer progression: a laboratory investigation. Anesth Analg. 2011; 112(3): 558-67.

90. Exadaktylos AK, Buggy DJ, Moriarty DC, Mascha E, Sessler DI. Can anesthetic technique for primary breast cancer surgery affect recurrence or metastasis? Anesthesiology. 2006; 105(4): 660-4.

91. Tsui BC, Rashiq S, Schopflocher D, Murtha A, Broemling S, Pillay J et al. Epidural anesthesia and cancer recurrence rates after radical prostatectomy. Can J Anaesth. 2010; 57(2): 107-12.

92. Zong J, Pollack GM. Morphine antinociception is enhanced in mdr1a gene-deficient mice. Pharm Res. 2000; 17(6): 749-753.

93. Sasamura T, Nakamura S, lida Y, Fujii H, Murata J, Saiki I et al. Morphine analgesia suppresses tumor growth and metastasis in a mouse model of cancer pain produced by orthotopic tumor inoculation. Eur J Pharmacol. 2002; 441(3): 185-191. 
94. Bortsov AV, Millikan RC, Belfer I, Boortz-Marx RL, Arora H, McLean SA. muOpioid receptor gene $\mathrm{A} 118 \mathrm{G}$ polymorphism predicts survival in patients with breast cancer. Anesthesiology. 2012; 116: 896-902.

95. Wang S, Li Y, Liu XD, Zhao CX, Yang KQ. Polymorphism of A118G in mu-opioid receptor gene is associated with risk of esophageal squamous cell carcinoma in a Chinese population. Int J Clin Oncol. 2013; 18(4): 666-9.

96. Afsharimani $\mathrm{B}$, Cabot $\mathrm{P}, \mathrm{Parat} \mathrm{MO}$. Morphine and tumor growth and metastasis. Cancer Metastasis Rev. 2011; 30(2): 225-38.

97. Hatsukari I, Hitosugi N, Ohno R, Hashimoto K, Nakamura S, Satoh K et al. Induction of apoptosis by morphine in human tumor cell lines in vitro. Anticancer Res. 2007; 27(2): 857-64.

98. Lennon FE, Moss J, Singleton PA. The $\mu$-opioid receptor in cancer progression: is there a direct effect? Anesthesiology. $2012 \mathrm{Apr} ; 116(4): 940-5$.

99. Singleton PA, Garcia JG, Moss J. Synergistic effects of methylnaltrexone with 5-fluorouracil and bevacizumab on inhibition of vascular endothelial growth factor-induced angiogenesis. Mol Cancer Ther. 2008; 7(6): 1669-79.

100. Singleton PA, Mambetsariev N, Lennon FE, Mathew B, Siegler JH, Moreno-Vinasco $L$ et al. Methylnaltrexone potentiates the anti-angiogenic effects of $m T O R$ inhibitors. J Angiogenes Res. 2010; 2(1): 5.

101. Farooqui M, Geng ZH, Stephenson EJ, Yee D, Gupta K. Naloxone acts as an antagonist of estrogen receptor in MCF7 cancer cells. Mol Cancer Ther. 2006; 5(3): 611-620.

102. Naltrexone in treating women with metastatic breast cancer that did not respond to hormone therapy. Disponible en: http://clinicaltrials.gov/ct2/show/ NCT00379197.

103. Low-dose naltrexone for glioma patients. Disponible en: http://clinicaltrials. gov/ct2/show/NCT01303835.

104. Zagon IS, Hytrek SD, Mclaughlin PJ. Opioid growth fac tor tonically inhibits human colon cancer cell proliferation in tissue culture. Am J Physiol. 1996; 271: R511-R518. 
105. Faramarzi N, Abbasi A, Tavangar SM, Mazouchi M, Dehpour AR. Opioid receptor antagonist promotes angiogenesis in bile duct ligated rats. J. Gastroenterol. Hepatol. 2009; 24: 1226-1229.

106. Miller. Tratado de Anestesia. Ed Harcourt Brace. 2263-2280.

107. Sessler DI. Regional anaesthesia and cancer recurrence risk. Rev Esp Anestesiol Reanim. 2008; 55(3): 133-4.

108. Buggy DJ, Smith G. Epidural anaesthesia and analgesia: better outcome after major surgery?. Growing evidence suggests so. BMJ. 1999; 319(7209): 530-1.

109. Bar-Yosef S, Melamed R, Page GG, Shakhar G, Shakhar K, Ben-Eliyahu S. Attenuation of the tumor-promoting effect of surgery by spinal blockade in rats. Anesthesiology. 2001 Jun; 94(6):1066-73.

110. Schlagenhauff B, Ellwanger U, Breuninger H, Stroebel W, Rassner G, Garbe C. Prognostic impact of the type of anaesthesia used during the excision of primary cutaneous melanoma. Melanoma Res. 2000; 10(2): 165-9.

111. Biki B, Mascha E, Moriarty DC, Fitzpatrick JM, Sessler DI, Buggy DJ. Anesthetic technique for radical prostatectomy surgery affects cancer recurrence: $A$ retrospective analysis. Anesthesiology. 2008; 109(2): 180-187.

112. Lin L, Liu C, Tan H, Ouyang H, Zhang Y, Zeng W. Anaesthetic technique may affect prognosis for ovarian serous adenocarcinoma: a retrospective analysis. $\mathrm{Br}$ J Anaesth. 2011; 106(6): 814-22.

113. De Oliveira GS Jr, Ahmad S, Schink JC, Singh DK, Fitzgerald PC, McCarthy RJ. Intraoperative neuraxial anesthesia but not postoperative neuraxial analgesia is associated with increased relapse-free survival in ovarian cancer patients after primary cytoreductive surgery. Reg. Anesth. Pain Med. 2011; 36 (3): 271-277.

114. Montélimard A MF, Nourissat A, Zufferey P, Molliex S. Can cervical epidural anesthesia improve survival in head and neck cancer surgery? ASA abstract 2010; A017.

115. Gottschalk K, Brodner G, Van Aken HK, Ellger B, Althaus S, Schulze H-J. Can regional anaesthesia for lymph-node dissection improve the prognosis in malignant melanoma? Br J Anaesth. 2012; 109(2): 253-9. 
116. Groetelaers RP, van Berlo CL, Nijhuis PH, Schapers RF, Gerritsen HA. Axillary recurrences after negative sentinel lymph node biopsy under local anaesthesia for breast cancer: a follow-up study after 5 years. Eur J Surg Oncol. 2008; 35(2): 159-63.

117. Lai R, Peng Z, Chen D, Wang X, Xing W, Zeng W et al. The effects of anesthetic technique on cancer recurrence in percutaneous radiofrequency ablation of small hepatocellular carcinoma. Anesth Analg. 2012 Feb; 114(2): 290-6.

118. Christopherson R, James KE, Tableman M, Marshall $P$, Johnson FE. Long term survival after colon cancer surgery: a variation associated with choice of anaesthesia. Anesth Analg. 2008; 107(1): 325-32.

119. Ismail H, Ho KM, Narayan K, Kondalsamy-Chennakesavan S. Effect of neuraxial anaesthesia on tumour progression in cervical cancer patients treated with brachytherapy: a retrospective cohort study. Br J Anaesth. 2010; 105(2):145-9.

120. Myles PS, Peyton P, Silbert B, Hunt J, Rigg JR, Sessler DI. Perioperative epidural analgesia for major abdominal surgery for cancer and recurrence-free survival: randomised trial. BMJ. 2011; 342: d1491.

121. Cummings KC 3rd, Xu F, Cummings LC, Cooper GS. A comparison of epidural analgesia and traditional pain management effects on survival and cancer recurrence after colectomy: a population-based study. Anesthesiology. 2012; 116(4): 797-806.

122. Cortiñas M, Mallol P, Martínez A, Pardo A. ¿Pueden las diferentes técnicas anestésicas empleadas en cirugía oncológica de mama disminuir el riesgo de recidiva tumoral?. Prog Obstet Ginecol. 2011; 54(2): 91—95.

123. Martin F, Martinez V, Mazoit JX, Bouhassira D, Cherif K, Gentili ME et al. Antiinflammatory effect of peripheral nerve blocks after knee surgery: clinical and biologic evaluation. Anesthesiology. 2008; 109(3): 484-90.

124. Viviano E, Renius M, Rückert JC, Bloch A, Meisel C, Harbeck-Seu A et al. Selective neurogenic blockade and perioperative immune reactivity in patient undergoing lung resection. J Int Med Res. 2012; 40 (1): 141-56.

125. Wada H, Seki S, Takahashi T, Kawarabayashi N, Higuchi H, Habu $Y$ et al. Combined spinal and general anesthesia attenuates liver metastasis by preserving TH1/TH2 cytokine balance. Anesthesiology. 2007; 106(3): 499-506. 
126. Le Cras AE, Galley HF, Webster N. Spinal but not general anesthesia increases the ratio of $\mathrm{T}$ helper 1 to $\mathrm{T}$ helper 2 cell subsets in patients undergoing transurethral resection of the prostate. Anesth Analg. 1998; 87(6): 1421-1425.

127. Zhou D, Gu FM, Gao Q, Li QL, Zhou J, Miao CH. Effects of anesthetic methods on preserving anti-tumor T-helper polarization following hepatectomy. World J Gastroenterol. 2012; 18(24): 3089-98.

128. Wuethrich PY, Hsu Schmitz SF, Kessler TM, Thalmann GN, Studer UE, Stueber $\mathrm{F}$ et al. Potential influence of the anesthetic technique used during open radical prostatectomy on prostate cancer-related outcome: a retrospective study. Anesthesiology. 2010; 113(3): 570-6.

129. Gupta A, Bjornsson A, Fredriksson M, Hallbook O, Eintrei C. Reduction in mortality after epidural anaesthesia and analgesia in patients undergoing rectal but not colonic cancer surgery: a retrospective analysis of data from 655 patients in central Sweden. Br J Anaesth. 2011; 107 (2): 164-170.

130. Hol JW, Stolker RJ, Klimek M, Stronks DL, Fekkes D. The tryptophan kynurenine pathway, neopterin and IL-6 during vulvectomy and abdominal hysterectomy. Journal of Biomedical Science. 2014; 21:102.

131. Deegan CA, Murray D, Doran P, Ecimovic P, Moriarty DC, Buggy DJ. Effect of anaesthetic technique on oestrogen receptor-negative breast cancer cell function in vitro. Br J Anaesth. 2009; 103(5): 685-90.

132. Sessler DI. Does regional analgesia reduce the risk of cancer recurrence? A hypothesis. Eur J Cancer Prev. 2008 Jun;17(3):269-72.

133. Regional anesthesia and breast cancer recurrence. Clinical Trials. Disponible en: http://clinicaltrials.gov/ct2/show/NCT00418457.

134. Regional anesthesia and endometrial cancer recurrence. Disponible en: http://clinicaltrials.gov/ct2/show/NCT00531349.

135. Regional anesthesia in colon rectal surgery. Clinical Trials. Disponible en: http://clinicaltrials.gov/ct2/show/NCT00684229.

136. The effect of adding intraoperative regional anesthesia on cancer recurrence in patients undergoing lung cancer resection. Clinical Trials. Disponible en: http://clinicaltrials.gov/ct2/show/NCT01179308. 
137. Epidural versus patient-controlled analgesia for reduction in long-term mortality following colorrectal cancer surgery. Disponible en http://clinicaltrials.gov/ ct2/show/NCT01318161.

138. Anesthesia and cancer recurrence in malignant melanoma. Disponible en: http://clinicaltrials.gov/ct2/show/NCT01588847.

139. Analgesia and pancreatic cancer surgery. Disponible en: http://clinicaltrials.gov/ct2/show/NCT01929915.

140. Regional anesthesia versus general anesthesia on circulating tumor cells (CTC). Disponible en: http://clinicaltrials.gov/ct2/show/NCT0171606.

141. Viale M, Minetti S, Ottone M, Lerza R, Parodi B, Pannacciulli I. Preclinical in vitro evaluation of hematotoxicity of the cisplatin-procaine complex DPR. Anti-Cancer Drugs. 2003; 14(2): 163-6.

142. Chlebowski RT, Block JB, Cundiff D, Dietrich MF. Doxorubicin cytotoxicity enhanced by local anesthetics in a human melanoma cell line. Cancer Treat Rep. 1982; 66(1): 121-5.

143. Mizuno S, Ishida A. Selective enhancement of the cytotoxicity of the bleomycin derivative, peplomycin, by local anesthetics alone and combined with hyperthermia. Cancer Res. 1982; 42(11): 4726-9.

144. Lirk $\mathrm{P}$, Berger $\mathrm{R}$, Hollmann MW, Fiegl $\mathrm{H}$. Lidocaine time- and dose dependently demethylates deoxyribonucleic acid in breast cancer cell lines in vitro. $\mathrm{Br}$ J Anaesth. 2012; 109: 200-7.

145. Piegeler T, Votta-Velis EG, Liu G, Place AT, Schwartz DE, Beck-Schimmer B et al. Antimetastatic potential of amide-linked local anesthetics: inhibition of lung adenocarcinoma cell migration and inflammatory Src signaling independent of sodium channel blockade. Anesthesiology. 2012; 117: 548-559.

146. De Klaver MJ, Weingart GS, Obrig TG, Rich GF. Local anesthetic- induced protection against lipopolysaccharide-induced injury in endothelial cells: The role of mitochondrial adenosine triphosphate-sensitive potassium channels. Anesth Analg. 2006; 102: 1108-13

147. Blumenthal S, Borgeat A, Pasch T, Reyes L, Booy C, Lambert M et al. Ropivacaine decreases inflammation in experimental endotoxin-induced lung injury. Anesthesiology. 2006; 104(5): 961-9. 
148. Herroeder S, Pecher S, Schönherr ME, Kaulitz G, Hahnenkamp K, Friess H et al. Systemic lidocaine shortens length of hospital stay after colorectal surgery: a double-blinded, randomized, placebo-controlled trial. Ann Surg. 2007; 246 (2): 192-200.

149. Karmakar MK. Thoracic paravertebral block. Anesthesiology. 2001; 95(3): 771-780.

150. Eason MJ, Wyatt R. Paravertebral thoracic block: a reappraisal. Anaesthesia. 1979; 34: 638-642.

151. Boezaart AP, Raw RM. Continuous thoracic paravertebral block for major breast surgery. Reg Anesth Pain Med. 2006; 31(5): 470-6.

152. Klein SM, Nielsen KC, Ahmed N, Buckenmaier CC, Steele SM. In Situ Images of the Thoracic Paravertebral Space. Reg Anesth Pain Med. 2004; 29(6): 596-599.

153. Haro Sanz F. Selección de técnicas para la anestesia en cirugía de mama. Confort en el periodo postoperatorio. Bloqueo intercostal-paravertebral. Puesta al día en anestesia regional y tratamiento del dolor. 1999; (2) 43-50.

154. Sopena-Zubiria LA, Fernández-Meré LA, Muñoz González F, Valdés Arias C. Bloqueo paravertebral torácico con punción múltiple en cirugía reconstructiva de la mama. Rev Esp Anestesiol Reanim. 2010; 57 (6):357-63.

155. Abrahams MS, Horn JL, Noles LM, Aziz MF. Evidence-based medicine: ultrasound guidance for truncal blocks. Reg Anesth Pain Med. 2010; 35 (Suppl 2): S36-42.

156. Karmakar MK, Li X, Li J, Hadzic A. Volumetric three-dimensional ultrasound imaging of the anatomy relevant for thoracic paravertebral block. Anesth Analg. 2012; 115(5): 1246-50.

157. Gómez Fernández M, Mateos Arribas T, Cuello Azcárate J, Vega Cruz S. Paravertebral block for major breast surgery in a patient with amyotrophic lateral sclerosis. Rev Esp Anestesiol Reanim. 2008; 55 (2): 124-5.

158. Esme H, Apilioqullari B, Duran FM, Yoldas B, Bekci TT. Comparison between intermittent intravenous analgesia and intermittent paravertebral subpleural analgesia for pain relief after thoracotomy. Eur J Cardiothorac Surg. 2012; 41 (1): 10-3. 
159. Ibarra Martí ML, S-Carralero G-Cuenca M, Vicente Gutiérrez U, Cuartero Del Pozo A, López Rincón R, Fajardo Del Castillo MJ. Comparación entre anestesia general con o sin bloqueo paravertebral preincisional con dosis única y dolor crónico postquirúrgico, en cirugía radical de cáncer de mama. Rev Esp Anestesiol Reanim. 2011; 58 (5): 290-294.

160. Naja ZM, El-Rajab M, Al-Tannir MA, Ziade FM, Tayara K, Younes F et al. Thoracic paravertebral block: influence of the number of injections. Reg Anesth Pain Med. 2006; 31(6): 196-201.

161. Richardson J, Lönnqvist PA. Thoracic paravertebral block. Br J Anaesth. 1998; 81 : 230-8.

162. Luyet C, Herrmann G, Ross S, Vogt A, Greif R, Moriggl B et al. Ultrasound-guided thoracic paravertebral puncture and placement of catheters in human cadavers: where do catheters go? Br J Anaesth. 2011; 106: 246-54.

163. Lemay E, Guay J, Côté C, Leclerc YE. Paravertebral blockade is not a suitable anesthetic technique for ambulatory minor breast surgery. Can J Anaesth. 2004 ; 51(8): 852-3.

164. Jaspars JJP, Posma AN, Van Immerseel J, Gittenberger-de Groot AC. The cutaneous inervation of the female breast and nipple-areola complex: implications for surgery. Br J Plast Surg. 1997; 50: 249-259.

165. Buggy DJ, Kerin MJ. Paravertebral Analgesia with Levobupivacaine Increases Postoperative Flap Tissue Oxygen Tension after Immediate Latissimus Dorsi Breast Reconstruction Compared with Intravenous Opioid Analgesia. Anesthesiology. 2004; 100: 375-80.

166. Munn DH, Zhou M, Attwood JT, Bondarev I, Conway SJ, Marshall B et al. Prevention of allogeneic fetal rejection by tryptophan catabolism. Science. 1998; 281 (5380): 1191-1193.

167. Munn DH, Shafizadeh E, Attwood JT, Bondarev I, Pashine A, Mellor AL. Inhibition of $\mathrm{T}$ cell proliferation by macrophage tryptophan catabolism. J Exp Med. 1999; 189(9): 1363-1372.

168. Friberg $M$, Jennings $R$, Alsarraj $M$, Dessureault $S$, Cantor $A$, Extermann $M$ et al. Indoleamine 2,3-dioxygenase contributes to tumor cell evasion of $\mathrm{T}$ cell-mediated rejection. Int J Cancer. 2002; 101(2): 151-155. 
169. Lindstöm V, Aittoniemi J, Jylhävä J, Eklund C, Hurme M, Paavonen T et al. Indoleamine-2,3-dioxygenase activity and expression in patients with chronic lymphocytic leukemia. Cin Lymphoma Myeloma Leuk. 2012; 12 (5): 363-5.

170. Nimomiya S, Hara T, Tsurumi H, Goto N, Saito K, Seishima M et al. Indoleamine 2,3-dioxygenase expression and serum kynurenine concentrations in patients with diffuse large B-cell lymphoma. Leuk Lymphoma. 2012 ; 53 (6): 1143-5.

171. Hara T, Tsurumi H. Rinsho Byori. Indoleamine 2, 3-dioxygenasase (IDO) as a prognostic factor of hematological malignancies. Rinsho Byori. 2011; 59(12): 1133-43.

172. Sakurai K, Fujisaki S, Nagashima S, Shibata M, Maeda T, Ueda Y et al. Study of indoleamine 2,3-dioxygenase expression in patients of thyroid cancer. Gan To Kagaku Ryoho. 2011; 38(12): 1927-9.

173. Engin AB, Ozkan Y, Fuchs D, Yardim-Akaydin S. Increased tryptophan degradation in patients with bronchus carcinoma. Eur J Cancer Care (Engl). 2010; 19(6): 803-8.

174. Hoshi M, Ito H, Fujigaki H, Takemura M, Takahashi T, Tomita E et al. Changes in serum tryptophan catabolism as an indicator of disease activity in adult T-cell leukemia/lymphoma. Leuk Lymphoma. 2009; 50(8): 1372-4.

175. Corm S, Berthon C, Imbenotte M, Biggio V, Lhermitte M, Dupont $C$ et al. Indoleamine 2,3-dioxygenase activity of acute myeloid leukemia cells can be measured from patients' sera by HPLC and is inducible by IFN-gamma. Leuk Res. 2009; 33(3): 490-4.

176. Fotopoulou C, Sehouli J, Pschowski R, VON Haehling S, Domanska G, Braicu El et al. Systemic changes of tryptophan catabolites via the indoleamine-2,3-dioxygenase pathway in primary cervical cancer. Anticancer Res. 2011; 31(8): 2629-35.

177. De Jong RA, Nijman HW, Boezen HM, Volmer M, Ten Hoor KA, Krijnen J et al. Serum tryptophan and kynurenine concentrations as parameters for indoleamine 2,3-dioxygenase activity in patients with endometrial, ovarian, and vulvar cancer. Int J Gynecol Cancer. 2011; 21(7): 1320-7.

178. Sperner-Unterweger B, Neurauter G, Klieber M, Kurz K, Meraner V, Zeimet A et al. Enhanced tryptophan degradation in patients with ovarian carcinoma co- 
rrelates with several serum soluble immune activation markers. Immunobiology. 2011; 216(3): 296-301.

179. Källberg E, Wikström P, Bergh A, Ivars F, Leanderson T. Indoleamine 2,3-dioxygenase (IDO) activity influence tumor growth in the TRAMP prostate cancer model. Prostate. 2010; 70 (13): 1461-70.

180. Sakurai K, Enomoto K, Amano S, Kimura T, Sugito K, Kimizuka K et al. Study of indoleamine 2,3-dioxygenase expression in patients of esophageal squamous cell carcinoma. Gan To Kagaku Ryoho. 2004; 31 (11): 1780-2.

181. Serum kynurenic acid: possible association with invasiveness of non-small cell lung cancer. Asian Pac J Cancer Prev. 2012; 13(9): 4241-4.

182. Nishiumi S, Kobayashi T, Ikeda A, Yoshie T, Kibi M, Izumi $Y$ et al. A novel serum metabolomics-based diagnostic approach for colorectal cancer. PLoS One. 2012; 7(7): e40459.

183. Munn DH, Sharma MD, Hou D, Baban B, Lee JR, Antonia SJ et al. Expression of indoleamine 2,3-dioxygenase by plasmacytoid dendritic cells in tumor draining lymph nodes. J Clin Invest. 2004; 114(2): 280-290.

184. Brandacher G, Perathoner A, Ladurner R, Schneeberger S, Obrist P, Winkler $C$ et al. Prognostic value of indoleamine 2,3-dioxygenase expression in colorectal cancer: effect on tumor-infiltrating T cells. Clin Cancer Res. 2006; 12(4): 1144-51.

185. Muller AJ, Sharma MD, Chandler PR, Duhadaway JB, Everhart ME, Johnson BA 3rd et al. Chronic inflammation that facilitates tumor progression creates local immune suppression by inducing indoleamine 2,3 dioxygenase. Proc Natl Acad Sci U S A. 2008;105 (44): 17073-8.

186. Ogawa K, Hara T, Shimizu M, Ninomiya S, Nagano J, Sakai H et al. Suppression of azoxymethane-induced colonic preneoplastic lesions in rats by 1-methyltryptophan, an inhibitor of indoleamine 2,3-dioxygenase. Cancer Sci. 2012; 103(5): 951-8.

187. Huang TT, Yen MC, Lin CC, Weng TY, Chen YL, Lin CM et al. Skin delivery of short hairpin RNA of indoleamine 2,3-dioxygenase induces antitumor immunity against orthotopic and metastatic liver cancer. Cancer Sci. 2011; 102(12): 2214-2220. 
188. Nakamura T, Shima T, Saeki A, HidakaT, Nakasima A, Takikawa 0 et al. Expression of indoleamin 2,3-dioxygenase andthe recruitment of Foxp3-expressing regulatory $\mathrm{T}$ cells in the development and progression of uterine cervical cancer. Cancer Sci. 2007; 98 (6): 874-81.

189. Levina V, Su Y, Gorelik E. Immunological and nonimmunological effects of indoleamine 2,3-dioxygenase on breast tumor growth and spontaneous metastasis formation. Clin Dev Immunol. 2012; 2012: 173029.

190. Xu H, Zhang GX, Ciric B, Rostami A. IDO: a double-edged sword for $T(H) 1 /$ $\mathrm{T}(\mathrm{H}) 2$ regulation. Immunol Lett. 2008; 121: 1-6.

191. Friberg $M$, Jennings $R$, Alsarraj $M$, Dessureault $S$, Cantor $A$, Extermann $M$ et al. Indoleamine 2,3-dioxygenase contributes to tumor cell evasion of T cell-mediated rejection. Int J Cancer. 2002; 101(2): 151-155.

192. Astigiano S, Morandi B, Costa R, Mastracci L, D'Agostino A, Ratto GB et al. Eosinophil granulocytes account for indoleamine 2,3-dioxygenase-mediated immune escape in human non-small cell lung cancer. Neoplasia. 2005; 7(4): 390-6.

193. 1-Methyl-D-Tryptophan in treating patients with metastatic or refractory solid tumors that cannot be removed by surgery. Disponible en: http://clinicaltrials. gov/ct2/show/NCT00567931

194. Yoshikawa T, Hara T, Tsurumi H, Goto N, Hoshi M, Kitagawa J et al. Serum concentration of L-kynurenine predicts the clinical outcome of patients with diffuse large B-cell lymphoma treated with R-CHOP. Eur J Haematol. 2010; 84(4): 304-9.

195. Weinlich G, Murr C, Richardsen L, Winkler C, Fuchs D. Decreased serum tryptophan concentration predicts poor prognosis in malignant melanoma patients. Dermatology. 2007; 214(1): 8-14.

196. Huang A, Fuchs D, Widner B, Glover C, Henderson DC, Allen-Mersh TG. Serum tryptophan decrease correlates with immune activation and impaired quality of life in colorectal cancer. Br J Cancer. 2002 Jun 5; 86(11): 1691-6.

197. Iwagaki H, Hizuta A, Tanaka N, Orita K. Decreased serum tryptophan in patients with cancer cachexia correlates with increased serum neopterin. Immunol Invest. 1995; 24(3): 467-78. 
198. Okamoto A; Nikaido T; Ochiai K; Takakura S; Saito M; Aoki Y et al. Indoleamine 2,3-dioxygenase serves as a marker of poor prognosis in gene expresión profiles of serous ovarian cancer cells. Clin. Cancer Res. 2005; 11: 6030-6039.

199. Sakurai K, Amano S, Enomoto K, Kashio M, Saito Y, Sakamoto A et al. [Study of indoleamine 2,3-dioxygenase expression in patients with breast cancer]. Gan To Kagaku Ryoho. 2005;32(11): 1546-1549.

200. Hoshi M, Ito H, Fujigaki H, Takemura M, Takahashi T, Tomita E et al. Indoleamine 2,3-dioxygenase is highly expressed in human adult T-cell leukemia/ lymphoma and chemotherapy changes tryptophan catabolism in serum and reduced activity. Leuk Res. 2009; 33(1): 39-45.

201. Sim SH, Ahn YO, Yoon J, Kim TM, Lee SH, Kim DW et al. Influence of chemotherapy on nitric oxide synthase, indole-amine-2,3-dioxygenase and CD124 expression in granulocytes and monocytes of non-small cell lung cancer. Cancer Sci. 2012; 103(2): 155-60.

202. Cavia-Saiz M, Muñiz P, De Santiago R, Herreros-Villanueva M, Garcia-Giron C, Lopez AS et al. Changes in the levels of thioredoxin and indoleamine-2,3-dioxygenase activity in plasma of patients with colorectal cancer treated with chemotherapy. Biochem Cell Biol. 2012; 90: 173-8.

203. Ou X, Cai S, Liu P, Zeng J, He Y, Wu X et al. Enhancement of dendritic ceII-tumor fusion vaccine potency by indoleamine-pyrrole 2,3-dioxygenase inhibitor, 1-MT. J Cancer Res Clin Oncol. 2008; 134(5): 525-33.

204. Gu T, Rowswell-Turner RB, Kilinc MO, Egilmez NK. Central role of IFNgamma-indoleamine 2,3-dioxygenase axis in regulation of interleukin-12-mediated antitumor immunity. Cancer Res. 2010; 70(1): 129-138.

205. Yang HJ, Yen MC, Lin CC, Lin CM, Chen YL, Weng TY et al. A combination of the metabolic enzyme inhibitor AP0866 and the immune adjuvant L-1-methyl tryptophan induces additive antitumor activity. Exp Biol Med (Maywood). 2010; 235(7): 869-876.

206. Hou D, Muller AJ, Sharma MD, DuHadaway J, Banerjee T, Johnson M et al. Inhibition of indoleamine 2,3-dioxygenase in dendritic cells by stereoisomers of 1-methyl-tryptophan correlates with antitumor responses. Cancer Res. 2007; 67(2): 792-801. 
207. Miyazaki T, Moritake K, Yamada K, Hara N, Osago H, Shibata T et al. Indoleamine 2,3-dioxygenase as a new target for malignant glioma therapy. Laboratory investigation. J Neurosurg. 2009; 111(2): 230-7.

208. Girgin G, Tolga Sahin T, Fuchs D, Kasuya H, Yuksel O, Tekin E et al. Immune system modulation in patients with malignant and benign breast disorders: tryptophan degradation and serum neopterin. Int J Biol Markers. 2009; 24(4): 265-70.

209. Sakurai K, Fujisaki S, Nagashima S, Maeda T, Shibata M, Gonda K et al. Analysis of indoleamine 2, 3-dioxygenase expression in breast cancer patients with bone metastasis. Gan To Kagaku Ryoho. 2012; 39(12): 1776-8.

210. Yu J, Sun J, Wang SE, Li H, Cao S, Cong Y, Liu J, Ren X. Upregulated expression of indoleamine 2, 3-dioxygenase in primary breast cancer correlates with increase of infiltrated regulatory $T$ cells in situ and lymph node metastasis. Clin Dev Immunol. 2011; 2011:469135.

211. Liu JT, Wei LJ, Yu JP, Li H, Li RM, Zang FL et al. [Expression of indoleamine 2, 3-dioxygenase and its correlation with prognosis in breast cancer patients]. Zhonghua Zhong Liu Za Zhi. 2011; 33(7): 513-6.

212. Jacquemeier J, Bertucci F, Finetti $P$, Esterni $B$, Charafe-Jauffret $E$, Thibult $M L$ et al. High expression of indoleamine 2,3-dioxygenase in the tumour is associated with medullary features and favourable outcome in basal-like breast carcinoma. Int J Cancer. 2012; 130 (1): 96-104.

213. Marfella A, Bilancio A, Polese C, lodice F, Edmondo C, Cerasuolo D et al. Urinary neopterin and kynurenine in patients submitted to surgical stress with different inhalational anesthetics (halothane or isoflurane). Int J Immunopharmacol. 1999; 21(7): 423-433.

214. Horowitz M, Neeman E, Sharon E, Ben-Eliyahu S. Exploiting the critical perioperative period to improve long-term cancer outcomes. Nat Rev Clin Oncol. 2015; 12(4):213-26.

215. Lee SK, Choi MY, Bae SY, Lee JH, Lee HC, Kil WH et al. Immediate Postoperative Inflammation Is an Important Prognostic Factor in Breast Cancer. Oncology. 2015. [Epub ahead of print]

216. Medina Fernández FJ, Muñoz-Casares FC, Arjona-Sánchez A, Casado-Adam A, Gómez-Luque I, Garcilazo Arismendi DJ et al. Postoperative Time Course and Utility of Inflammatory Markers in Patients with Ovarian Peritoneal Carcinomato- 
sis Treated with Neoadjuvant Chemotherapy, Cytoreductive Surgery, and HIPEC. Ann Surg Oncol. 2015 Apr;22(4):1332-40. Epub 2014 Sep 19.

217. Peng W, Li C, Wen TF, Yan LN, Li B, Wang WT et al. Neutrophil to lymphocyte ratio changes predict small hepatocellular carcinoma survival. J Surg Res. 2014 Dec;192(2):402-8..

218. Forget $P$, Machiels JP, Coulie PG, Berliere M, Poncelet AJ, Tombal B, Stainier A, Legrand C, Canon JL, Kremer Y, De Kock M. Neutrophil:lymphocyte ratio and intraoperative use of ketorolac or diclofenac are prognostic factors in different cohorts of patients undergoing breast, lung, and kidney cancer surgery. Ann Surg Oncol. 2013; 20 Suppl 3: S650-60.

219. Forget $P$, Moreau $N$, Engel $H$, Cornu $O$, Boland B, De Kock M, Yombi JC. The neutrophil-to-lymphocyte ratio (NLR) after surgery for hip fracture (HF). Arch Gerontol Geriatr. 2015; 60(2): 366-71.

220. Forget $P$, Dinant V, De Kock $M$. Is the Neutrophil-to-Lymphocyte Ratio more correlated than C-reactive protein with postoperative complications after major abdominal surgery? PeerJ; 3: e713.

221. Zhang $X$, Zhang $W$, Feng $L$. Prognostic significance of neutrophil lymphocyte ratio in patients with gastric cancer: a meta-analysis. PLoS One. 2014; 9(11): e111906.

222. Templeton AJ, McNamara MG, Šeruga $B$, Vera-Badillo FE, Aneja $P$, Ocaña $A$ et al. Prognostic role of neutrophil-to-lymphocyte ratio in solid tumors: a systematic review and meta-analysis. J Natl Cancer Inst. 2014; 106(6): dju124.

223. Malietzis G, Giacometti M, Kennedy RH, Athanasiou T, Aziz O, Jenkins JT. The emerging role of neutrophil to lymphocyte ratio in determining colorectal cancer treatment outcomes: a systematic review and meta-analysis. Ann Surg Oncol. 2014; 21(12): 3938-46.

224. Xue TC, Zhang L, Xie XY, Ge NL, Li LX, Zhang BH et al. Prognostic significance of the neutrophil-to-lymphocyte ratio in primary liver cancer: a meta-analysis. PLoS One. 2014; 9(5): e96072.

225. Wei Y, Jiang YZ, Qian WH. Prognostic role of NLR in urinary cancers: a meta-analysis. PLoS One. 2014; 9(3): e92079. 
226. Xiao WK, Chen D, Li SQ, Fu SJ, Peng BG, Liang LJ.Prognostic significance of neutrophil-lymphocyte ratio in hepatocellular carcinoma: a meta-analysis. BMC Cancer. 2014; 14: 117.

227. Paramanathan A, Saxena A, Morris DL.A systematic review and meta-analysis on the impact of pre-operative neutrophil lymphocyte ratio on long term outcomes after curative intent resection of solid tumours. Surg Oncol. 2014; 23(1): 31-9.

228. Li MX, Liu XM, Zhang XF, Zhang JF, Wang WL, Zhu Y et al. Prognostic role of neutrophil-to-lymphocyte ratio in colorectal cancer: a systematic review and meta-analysis. Int J Cancer. 2014; 134(10): 2403-13.

229. Choi JE, Villarreal J, Lasala J, Gottumukkala V, Mehran RJ, Rice D et al. Perioperative neutrophil:lymphocyte ratio and postoperative NSAID use as predictors of survival after lung cancer surgery: a retrospective study. Cancer Med. 2015;4(6):825-33.

230. Cihan YB, Arslan A, Cetindag MF, Mutlu H. Lack of prognostic value of blood parameters in patients receiving adjuvant radiotherapy for breastcancer. Asian Pac J Cancer Prev. 2014; 15(10): 4225-31.

231. Azab B, Shah N, Radbel J, Tan P, Bhatt V, Vonfrolio S et al. Pretreatment neutrophil/lymphocyte ratio is superior to platelet/lymphocyte ratio as a predictor of long-term mortality in breast cancer patients. Med Oncol. 2013; 30(1): 432.

232. Engin H, Bilir C, Tekin IO. Prognostic significance of peripheral blood flow cytometry parameters in patients with non-metastaticbreast cancer. Asian Pac J Cancer Prev. 2013; 14(12): 7645-9.

233. De Giorgi U, Mego M, Scarpi E, Giuliano M, Giordano A, Reuben JM et al. Relationship between lymphocytopenia and circulating tumor cells as prognostic factors for overall survival in metastatic breast cancer. Clin Breast Cancer. 2012; 12(4): 264-9.

234. Vicente Conesa MA, Garcia-Martinez E, Gonzalez Billalabeitia E, Chaves Benito A, Garcia Garcia T, Vicente Garcia V et al. Predictive value of peripheral blood lymphocyte count in breast cancer patients treated with primary chemotherapy. Breast. 2012; 21(4): 468-74.

235. Azab B, Bhatt VR, Phookan J, Murukutla S, Kohn N, Terjanian T et al. Usefulness of the neutrophil-to-lymphocyte ratio in predicting short- and long-term mortality in breast cancer patients. Ann Surg Oncol. 2012; 19(1): 217-24. 
236. Hole A. Per- and postoperative monocyte and lymphocyte functions: effects of sera from patients operated under general or epidural anaesthesia. Acta Anaesthesiol Scand. 1984; 28(3): 287-91.

237. Jakobsen BW, Pedersen J, Egeberg BB. Postoperative lymphocytopenia and leucocytosis after epidural and general anaesthesia. Acta Anaesthesiol Scand. 1986; 30(8): 668-71.

238. Jaura AI, Flood G, Gallagher HC, Buggy DJ. Differential effects of serum from patients administered distinct anaesthetic techniques on apoptosis in breast cancer cells in vitro: a pilot study. Br J Anaesth. 2014; 113 Suppl 1: i63-7.

239. Volk T, Schenk M, Voigt K, Tohtz S, Putzier M, Kox WJ. Postoperative epidural anesthesia preserves lymphocyte, but not monocyte, immune function after major spinesurgery. Anesth Analg. 2004 Apr;98(4):1086-92

240. Rem J, Brandt MR, Kehlet H. Prevention of postoperative lymphopenia and granulocytosis by epidural analgesia. Lancet. 1980 Feb 9;1(8163):283-4.

241. Goto Y, Ho SL, McAdoo J, Fanning NF, Wang J, Redmond HP, Shorten GD. General versus regional anaesthesia for cataract surgery: effects on neutrophil apoptosis and the postoperative pro-inflammatory state. Eur J Anaesthesiol. 2000 Aug;17(8):474-80.

242. Vuori A, Salo M, Viljanto J, Pajulo 0 , Pulkki $K$, Nevalainen $T$. Effects of post-operative pain treatment using non-steroidal anti-inflammatory analgesics, opioids or epidural blockade on systemic and local immune responses in children. Acta Anaesthesiol Scand. 2004; 48 (6): 738-49.

243. Hong JY, Lim KT. Effect of preemptive epidural analgesia on cytokine response and postoperative pain in laparoscopic radicalhysterectomy for cervical cancer. Reg Anesth Pain Med. 2008; 33(1):44-51.

244. Wu J, Buggy D, Fleischmann E, Parra-Sanchez I, Treschan T et al , Thoracic paravertebral regional anesthesia improves analgesia after breast cancer surgery: a randomized controlled multicentre clinical trial. Can J Anesth/J Can Anesth. $2015 ; 62: 241-251$.

245. Sundarathiti $P$, von Bormann $B$, Suvikapakornkul R, Lertsithichai $P$, Arnuntasupakul V. Paravertebral Catheter for Three-Level Injection in Radical Mastectomy: A Randomised Controlled Study. PLoS One. 2015; 9;10 (6): e0129539. 
246. Forrest CM, Mackay GM, Oxford L, Millar K, Darlington LG, Higgins MJ et al. Kynurenine metabolism predicts cognitive function in patients following cardiac bypass and thoracic surgery. J Neurochem. 2011; 119(1): 136-152.

247. Yao M, Liu Y, Jin H, Liu X, Lv K et al. Prognostic value of preoperative inflammatory markers in Chinese patients with breast cancer. Onco Targets and Therapy. 2014; 7, 1743-1752.

248. Balta S, Demirkol S, Kucuk U, Sarlak H, Kurt O et al. Neutrophil to lymphocyte ratio may predict mortality in breast cancer patients. J Breast Cancer. 2013; 16 (3): 354-355.

249. Noh H, Eomm M, Han A. Usefulness of pretreatment neutrophil to lymphocyte ratio in predicting disease-specific survival in breast cancer patients. J Breast Cancer. 2013; 16: 55-59.

250. Ozyalvacli G, Yesil C, Kargi E, Kizildag B, Kilitci A et al. Diagnostic and prognostic importance of the neutropil to lymphocyte ratio in breast cancer. Asian Pac J Cancer Prev. 2014; 15 (23): 10363-10366.

251. Cook EJ, Walsh SR, Farooq N, Alberts JC, Justin TA, Keeling NJ. Post-operative neutrophil-lymphocyte ratio predicts complications following colorectal surgery. Int J Surg. 2007; 5(1): 27-30.

252. Xu YJ, Chen WK, Zhu Y, Wang SL, Miao CH. Effect of thoracic epidural anaesthesia on serum vascular endothelial growth factor $\mathrm{C}$ and cytokines in patientsundergoing anaesthesia and surgery for colon cancer. Br J Anaesth. 2014; 113 Suppl 1: i49-55.

253. Chen J, Deng Q, Pan Y, He B, Ying H, Sun H et al. Prognostic value of neutrophil-to-lymphocyte ratio in breast cancer. FEBS Open Bio. 2015. 12;5:502-7.

254. Cook EJ, Walsh SR, Farooq N, Alberts JC, Justin TA, Keeling NJ. Post-operative neutrophil-lymphocyte ratio predicts complications following colorectal surgery. Int J Surg. 2007; 5(1): 27-30.

255. Sato H, Tsubosa Y, Kawano T. Correlation between the pretherapeutic neutrophil to lymphocyte ratio and the pathologic response to neoadjuvant chemotherapy in patients with advanced esophageal cancer. World J Surg. 2012; 36(3): 617-22. 
256. Akilli NB, Yortanlı M, Mutlu H, Günaydın YK, Koylu R, Akca HS et al. Prognostic importance of neutrophil-lymphocyte ratio in critically ill patients: short- and long-term outcomes. Am J Emerg Med. 2014 Dec;32(12):1476-80.

257. Terradas R, Grau S, Blanch J, Riu M, Saballs P, Castells X, et al. Eosinophil count and neutrophil-lymphocyte count ratio as prognostic markers in patients with bacteremia: a retrospective cohort study. PLoS One. 2012;7(8):e42860.

258. Gibson PH, Croal BL, Cuthbertson BH, Small GR, Ifezulike Al, Gibson G et al. Preoperative neutrophil-lymphocyte ratio and outcome from coronary artery bypass grafting. Am Heart J. 2007 Nov;154(5):995-1002.

259. Seretis C, Gourgiotis S, Gemenetzis G, Seretis F, Lagoudianakis E, Dimitrakopoulos $\mathrm{G}$.The significance of neutrophil/lymphocyte ratio as a possible marker of underlying papillary microcarcinomas in thyroidal goiters: a pilot study. Am J Surg. 2013 Jun;205(6):691-6.

260. Peng W, Li C, Wen TF, Yan LN, Li B, Wang WT et al. Neutrophil to lymphocyte ratio changes predict small hepatocellular carcinoma survival. J Surg Res. 2014 Dec;192(2):402-8.

261. Vasileiou I, Xanthos T, Koudouna E, Perrea D, Klonaris C, Katsargyris A et al. Propofol: a review of its non-anaesthetic effects. Eur J Pharmacol. 2009 Mar 1; 605(1-3):1-8.

262. Cavia-Saiz M, Muñiz Rodríguez $P$, Llorente Ayala $B$, García-González M, Coma-Del Corral MJ, García Girón C. The role of plasma IDO activity as a diagnostic marker of patients with colorectal cancer. Mol Biol Rep. 2014; 41 (4):2275-9.

263. Forget P, Bentin C, Machiels JP, Berliere M, Coulie PG, De Kock M.Intraoperative use of ketorolac or diclofenac is associated with improved disease-free survival and overall survival in conservative breast cancer surgery. Br J Anaesth. 2014; 113 Suppl 1: i82-7. 
